PAULO FRAZÃO

\title{
A PARTICIPAÇÃO DO PESSOAL AUXILIAR ODONTOLÓGICO EM DEZ SISTEMAS LOCAIS DE SAÚDE DE CINCO MUNICÍPIOS NO ESTADO DE SÃO PAULO, 1994.
}

Dissertação de Mestrado apresentada à Faculdade de Saúde Pública da Universidade de São Paulo, Departamento de Prática de Saúde Pública, para obtenção do título de "Mestre em Saúde Pública".

Orientador: PROF. DOUTOR ANTONIO GALVÃO F. ROSA 
Aos meus pais, pelo estímulo e apoio, permanentes.

\author{
À Marisa, \\ pela compreensão ao tempo roubado, \\ e carinho no compartilhado
}


Este trabalho de investigação foi concluído em virtude do apoio do Centro de Saúde-Escola "Geraldo Paula Souza" da Faculdade de Saúde Pública da USP; do Centro de Formação dos Trabalhadores da Saúde da SMS-SP e da CAPES. Sou grato à estas instituições. 


\section{AGRADECIMENTOS}

Ao Prof. Doutor Antonio Galvão F. Rosa,

pelas horas de dedicação no trabalho de orientação;

Aos auxiliares, do Centro de Saúde-Escola "Geraldo Paula Souza" , da UBS Canhema de Diadema , e aos alunos do curso de auxiliar de consultório dentário do Distrito de Saúde do Ipiranga, pela solicitude e paciência para participar das entrevistas durante o estudo exploratório;

Aos alunos do curso de técnico em higiene dental dos distritos sanitários da Administração Regional de Saúde - 7 da SMS-SP, pelas sugestōes durante o pré-teste do instrumento de coleta de dados;

À todos os trabalhadores que exercem funçōes auxiliares nos serviços públicos odontológicos, razão e fonte primária desta investigação, em especial, aos auxiliares e técnicos em higiene dental dos sistemas municipais de saúde de Itú, Embú, Penápolis, São José dos Campos e Campinas que prontamente responderam o questionário e participaram da pesquisa;

A Prof. Doutora Edméa Rita Temporini, pela orientação no processo de construção do instrumento de coleta de dados;

Ả Prof. Maria do Rosário Dias de Oliveira Latorre, pela orientação no tratamento estatistico dos dados;

Aos Profs. do Departamento de Prática de Saúde Pública, em especial,

aos Profs. Roberto A. Castellanos e Paulo Capel Narvai, pelo apoio e amizade no sonho de organizações e de sociedades mais justas e democráticas;

À colega e Prof. Déborah Rachel Audebert Delage Silva, pela atenção sempre dedicada, em especial, à tarefa de revisão da tradução em lingua inglesa;

Ao Serviço de Biblioteca e Documentação da Faculdade de Saúde Pública da USP, pelo trabalho de busca das fontes e de revisão das referências bibliográficas;

Aos colegas, técnicos e administradores de senviços públicos odontológicos, em especial aos coordenadores dos serviços públicos odontológicos das cidades de Itú, Embú, Penápolis, São José dos Campos e Campinas, pela solidariedade na luta cotidiana do processo da reforma sanitária brasileira;

Aos colegas, coordenadores, instrutores e monitores de cursos de qualificação profissional dos centros formadores, pelo respeito mútuo e pela amizade no trabalho árduo do dia-a-dia;

Aos colegas docentes do Curso de Odontologia da Faculdade de Ciências Biológicas e da Saúde da Universidade Metodista de São Paulo, na pessoa do Prof. Antonio Alves Garcia pela compreensão e apoio sempre demonstrado;

A todos os funcionários do HSP e da Pós-graduação da FSP-USP, representados pelo Etevaldo, minha gratidão pelo auxilio e pelo tratamento sempre dispensado. 
--. Como você vê a resposta da população ?

-- A gente vê muito isso daí pelos retornos, porque é feito o tratamento inicial completo e depois tem o retorno de seis meses, um acompanhamento, que seria como a manutenção, então a gente vê, dá prá sentir mais essa resposta no retorno, vem muito, retorna, inclusive, a gente, acho que no mês passado, não tava conseguindo dar conta desse retorno, aí está a resposta.

- E o estado de saúde bucal, quando eles retornam, como é ?

-- Ah! normalmente, quase sempre é só flúor mesmo, alguns às vezes tem alguma coisinha prá fazer, mas normalmente a resposta é muito boa. Eu acho que quando, há três anos atrás, começou este negócio de prevenção, era de uma maneira, parece que era mais, foi na semana passada que eu acompanhei o Dr. Paulo, fizemos o levantamento epidemiológico nas escolas, e não sei se essa prevenção, essa aplicação do flúor, o que é, mas o resultado foi praticamente satisfatório. Fizemos uma avaliação de cárie crônica, ativa e mancha, então tava bem menos; que quando há dois anos atrás, eu acompanhei a Dra. Edna, nós ficamos um tempão enorme prá poder dar conta, teve um trabalho danado, inclusive de sábado, muita criança com a boca atrapalhada. Agora, têve classe que a gente pegou assim, que tinha três ou quatro criança prá fazer tratamento inicial, então a maioria com a boquinha realmente boa, umas manchinha, mas cárie mesmo, muito pouco. Então, acho uma boa resposta, não sei se a prevenção, se o trabalho todo que foi feito, mas desta vez no levantamento que foi feito, eu admirei, achei que tava muito bom.

(Extraído de um depoimento de uma das auxiliares entrevistadas durante o estudo exploratório ) 


\section{SUMÁRIO}

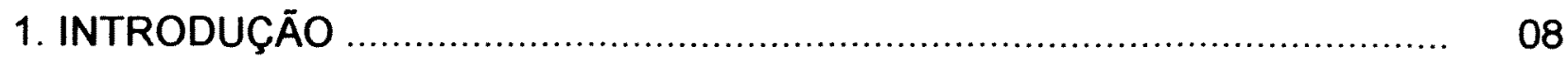

1.1 Os recursos humanos no Sistema Único de Saúde ................................ 08

1.2. O pessoal auxiliar odontológico no SUS ........................................... 10

1.3. Diretrizes de saúde bucal no SUS ..................................................... 12

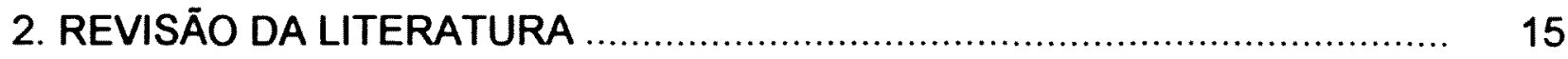

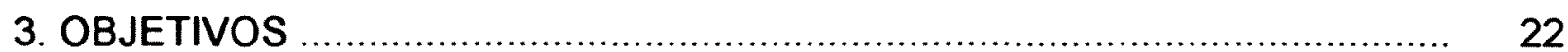

4. PROCEDIMENTOS METODOLÓGICOS ….............................................. 23

4.1. A natureza do objeto .................................................................. 23

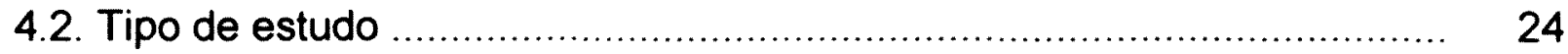

4.3. População de estudo ............................................................. 25

4.4. Caracterização dos municipios ........................................................ 25

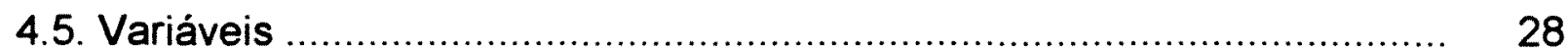

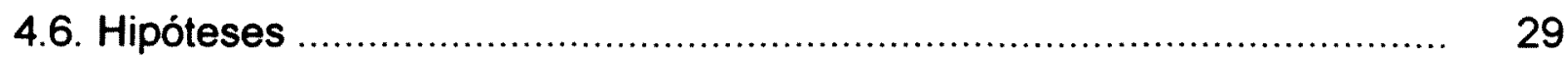

4.7. A construção do questionário ......................................................... 29

4.8. Coleta dos dados ...................................................................... 31

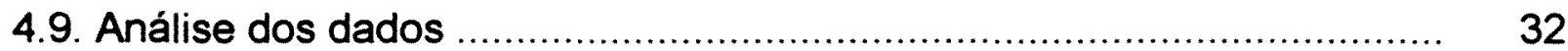

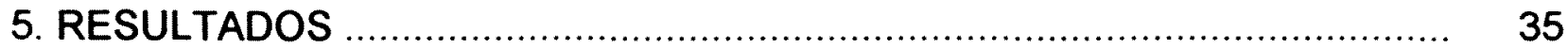

5.1. Características demográficas ......................................................... 36

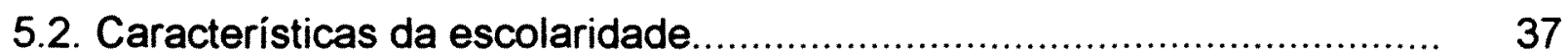

5.3. Características do vínculo empregatício............................................. 40

5.4. Características da participação em ações coletivas ............................. 44

5.5. Características da participação na assistência individual .................... 55

5.6. Características da opinião ............................................................. 60

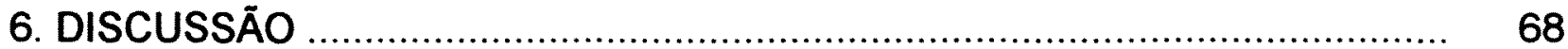

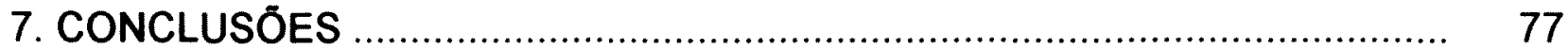

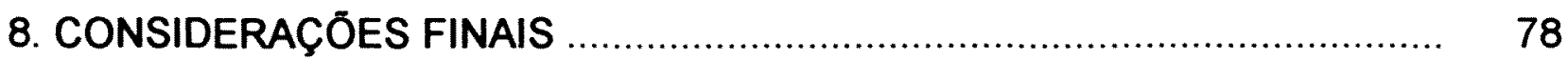

9. REFERÉNCIAS BIBLIOGRÁFICAS …..................................................... 80

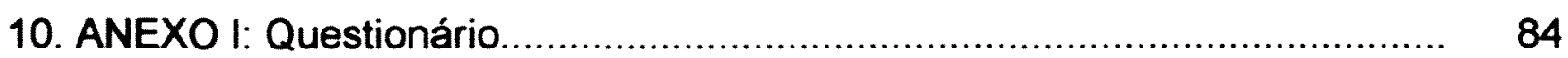

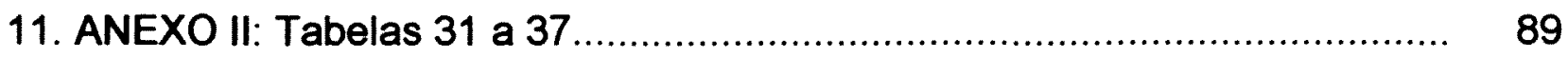




\section{SUMÁRIO DAS TABELAS}

1. Distribuição do pessoal auxiliar odontológico empregado, e que respondeu ao questionário segundo a função que exerce e o sistema local de saúde pesquisado, 1994.

2. Distribuição da população de estudo segundo o sexo, 1994.

3. Distribuição da população de estudo segundo a idade, 1994.

4. Distribuição da população de estudo segundo o grau de escolaridade e o município, 1994.

5. Distribuição da população de estudo segundo a função exercida e a realização de curso de formação profissional por municipio, 1994.

6. Frequência do pessoal auxiliar que declarou estar realizando curso de formação de ACD ou de THD por municipio, 1994.

7. Número e percentual do pessoal auxiliar auxiliar que tem interesse em fazer curso de ACD ou de THD segundo o municipio. 1994.

8. Números de horas-trabalho por mês declarados pelo pessoal auxiliar segundo o local e o município, 1994.

9. Número de horas-trabalho por mês declarados pelo pessoal auxiliar do município de $\mathrm{S}$. José dos Campos segundo o local de trabalho e o sistema local de saúde, 1994.

10. Número de horas-trabalho por mês declarados pelo pessoal auxiliar do município de Campinas segundo o local de trabalho e o sistema local de saúde, 1994.

11. Número de horas-trabalho por mês declarados pelo pessoal que exerce a função de ACD segundo o local de trabalho e o municipio, 1994.

12. Número de horas-trabalho por mês declarados pelo pessoal que exerce a função de THD segundo o local e o município, 1994.

13. Número e percentual do pessoal que auxilia ou já auxiliou o dentista nas atividades de exame ou levantamento de cárie dentária em grupos populacionais segundo a função que exerce e o sistema local de saúde, 1994.

14. Distribuição estimada do tempo da jornada mensal de trabalho do pessoal auxiliar dispendido em atividades coletivas de evidenciação de placa seguida de escovação supervisionada e aplicação de flúor com escova ou moldeira, e atividades na assistência individual em unidades básicas de saúde segundo o sistema local de saúde, 1994.

15. Distribuição estimada do tempo da jornada mensal de trabalho do pessoal auxiliar dispendido em atividades coletivas de evidenciação de placa seguida de escovação supervisionada, bochechos fluorados e aplicação de flúor com escova ou moldeira e atividades na assistência individual em escolas e outros espaços sociais segundo o sistema local de saúde, 1994.

16. Número e percentual do pessoal auxiliar segundo a função e a realização de tarefas na assistência individual, 1994. 
17. Número e percentual do pessoal auxiliar que trabalha à quatro-mãos segundo a função e o sistema local de saúde, 1994.

18. Número e percentual do pessoal auxiliar que realiza tarefas na assistência individual segundo o tipo de atividade e a função. 1994.

19. Número e percentual do pessoal auxiliar segundo a função e a realização de aplicação tópica de flúor na assistência individual por municipio, 1994.

20. Número e percentual de THDs que na assistência individual executam aplicação de selante, aplicação de cariostático, e polimento dentário por municipio, 1994.

21. Número e percentual de THDs que na assistência individual, executam remoção de tártaro (RT), inserção e condensação de materiais restauradores (CR) por município, 1994

22. Distribuição do pessoal auxiliar segundo a opinião em relação à questão: " Durante as atividades de prevenção da cárie dentária (escovaçðes, bochechos, orientaçðes etc.) que você realiza, as pessoas que recebem essas atividades:". Em dez sistemas locais de saúde. 1994.

23. Distribuição do pessoal auxiliar segundo a opinião em relação à questão: "Você considera o relacionamento profissional dos dentistas com você:". Em dez sistemas locais de saúde. 1994.

24. Distribuição do pessoal auxiliar segundo a opinião em relação à questão: " Durante o trabalho, os dentistas:". Em dez sistemas locais de saúde, 1994.

25. Distribuição do pessoal auxiliar segundo a opinião em relação à questão: " você acha que os dentistas devem:". Em dez sistemas locais de saúde, 1994.

26. Opinião do pessoa auxiliar odontológico sobre o comportamento dos dentistas (CDs) durante atividades de supervisão e sua expectativa segundo o municipio, 1994.

27. Distribuição do pessoal auxiliar segundo a opinião em relação à questão: "Você considera o relacionamento profissional de outros auxiliares com você:". Em dez sistemas locais de saúde, 1994.

28. Distribuição do pessoal auxiliar segundo a opinião em relação à questão: " Durante o trabalho, os auxiliares:". Em dez sistemas locais de saúde, 1994.

29. Distribuição do pessoal auxiliar segundo a opinião em relação à questão: " Deve-se aumentar o número de auxiliares para: ". Frequência absoluta e relativa em dez SILOS, 1994.

30. Distribuição do pessoal auxiliar segundo a opinião em relação à questão: " Deve-se aumentar o número de auxiliares para: " e o município, 1994. Frequência absoluta e relativa. 


\section{SUMÁRIO DOS GRÁFICOS}

1. Salário médio em dolar declarado pelo pessoal auxiliar segundo a função por municipio, 1994.

2. Percentual de auxiliares (ACD+THD) que fazem bochechos fluorados segundo o local de trabalho por SILOS, 1994.

3. Percentual de auxiliares (ACD+THD) que fazem evidenciação de placa seguida de escovacão supervisionada segundo o local de trabalho por SILOS, 1994.

4. Percentual de auxiliares (ACD+THD) que fazem aplicação de flúor com escova ou moldeira segundo o local de trabalho por SILOS, 1994.

5. Percentual de auxiliares (ACD+THD) que fazem atividades educativas segundo o local de trabalho por SILOS, 1994.

6. Número médio de pessoas beneficiadas mensalmente em escolas e outros espaços sociais por auxiliar segundo o tipo de acão coletiva e o SILOS, 1994.

7. Média de horas por semana de auxiliares (ACD+THD) dispendidas com ações coletivas em escolas e outros espacos sociais segundo o SILOS, 1994.

8. Número médio de pessoas beneficiadas mensalmente em unidades básicas de saúde por auxiliar segundo o tipo de acão coletiva e o SILOS, 1994.

9. Média de horas por semana de auxiliares (ACD+THD) dispendidas com açōes coletivas em unidades básicas de saúde segundo o SILOS, 1994.

10. Tempo de jornada de trabalho de auxiliares (ACD+THD) dispendido em açōes coletivas segundo o local de trabalho por SILOS, 1994. Percentual. 


\section{RESUMO}

Título: A PARTICIPAÇÃO DO PESSOAL AUXILIAR ODONTOLÓGICO EM DEZ SISTEMAS LOCAIS DE SAÚDE DE CINCO MUNICIPIOS NO ESTADO DE SÃO PAULO, 1994.

Unitermos: Saúde Pública - Sistemas locais de saúde - programas odontológicos - pessoal auxiliar odontológico

No final da década dos 70 e inicio da década dos 80 , em diferentes regiðes do Brasil, os serviços públicos - tanto aqueles existentes quanto aqueles começando a se estruturar - passam a utilizar pessoal de nivel elementar e médio para auxiliar nas açôs de atenção à saúde bucal. No Estado de São Paulo, embora inúmeros sistemas locais de saúde (SILOS) venham empregando pessoal auxiliar odontológico (PAO), existe pouca informaçāo disponivel sobre a contribuiçāo dada por estes trabalhadores à essas açôes. O objetivo desta investigação foi de analisar a participação do PAO em dez SILOS de cinco municipios do Estado de São Paulo, em 1994. Um questionário foi respondido por $248(76,3 \%)$ dos 325 auxiliares e técnicos em higiene dental empregados nos municipios de Itú, Embú, Penápolis, São José dos Campos e Campinas. Os resultados indicaram que a maioria do PAO é jovem, do sexo feminino, possui $2^{\circ}$ grau completo, curso de qualificação profissional, tem vínculo municipal e trabalha 40 horas/semana, sendo que, recebem entre US\$ 119,00 e US $\$ 330,00$ no exercicio da função de ACD e entre US $\$ 162,00$ e US\$ 232,00 como THD. Sua participação em atividades de promoção da saúde bucal é relativa e varia conforme o SILOS em estudo: nos SILOS do Embú e das regioes norte e leste de S. José do Campos, o PAO vem dedicando sua jornada de trabalho mais para açóes coletivas que para açós de assistência individual, contribuindo para a transformaçāo das práticas da odontologia em saúde coletiva e para a mudança do modelo assistencial conforme as diretrizes de saúde bucal e os principios do SUS. A participação do PAO é mais frequente em atividades de evidenciação de placa bacteriana seguida de escovação supervisionada (ES), bochechos fluorados e atividades educativas. A participação em ações coletivas é maior quando se trata da realização dessas atividades em escolas ou outros espaços sociais. Entretanto, em Itú. Embú e Penápolis, o pessoal auxiliar desenvolve de forma significativa atividades de ES em unidades básicas de saúde, atingindo com atividades de promoção da saúde bucal grupos populacionais que as frequentam. Excetuando-se os três SILOS de Campinas e o de Itú, é baixa a proporção do PAO que trabalha à quatro-mãos rotineiramente. Os SILOS de Itú, Embủ e Penápolis apresentam maior grau de delegação de funçōes ao PAO na assistência individual que os SILOS dos municipios de São José dos Campos e Campinas. Segundo o pessoal auxiliar, a população-usuária reage positivamente e aceita bem os seus serviços. Além disso, os cirurgiōes-dentistas têm um relacionamento profissional bom ou muito bom com eles, prestam-lhes orientaçōes sempre que necessário e, na opinião deles, devem manter o grau de orientação corrente. 


\section{SUMMARY}

Title: THE ROLE OF DENTAL AUXILIARY PERSONNEL IN TEN HEALTH LOCAL SYSTEMS OF FIVE TOWNS IN SÃO PAULO STATE. 1994.

Key words: Public health - health local systems - oral health programmes - dental auxiliary personnel

At the end of the seventies and begining of the eighties, dental public services from different areas of Brazil started to introduce basically and intermediately trainned personnel to assist dental care activities. This happened both in services in operation at the time and in those which were begining to be structured. In São Paulo State, although several health local systems are employing dental auxiliary personnel, we know there is a small number of studies in this field and also little information about this personnel. The purpose of this survey was to document the role and extent of dental auxiliary personnel in some state public health programmes in São Paulo State, 1994. A questionnaire requested information from $248(76,3 \%)$ auxiliaries of 325 dental assistants and dental hygienists employed in the health municipal systems of Itú, Embú, Penápolis, São José dos Campos and Campinas (towns in São Paulo State). The results indicated that most of them are young, female sex, went through high school and professional qualification course, work forty hours a week and receive between US\$ 119,00 and US $\$ 330,00$ in dental assistant function and between US\$ 162,00 and US\$232,00 in dental hygienist function. Their participation in oral healh promotion activities is relative and varies according to each town reality: in Embu and in the north and east health local systems of São José dos Campos, the working time of auxiliary personnel is spent more in oral health promotion activities than in dental clinic activities, contributing to the transformation of public health dentistry practice according to the principles of health systems in Brazil. This participation occurs more often in fluoride mouthrinse, dental plaque staining followed by supervised brushing and oral health education activities. The participation in oral health promotion activities happens more often in schools than in health centers. However, in Itú, Embú and Penápolis, the auxiliaries provide expressively dental plaque staining followed by supervised brushing in health centers, reaching population groups who use them. Excluding the health local systems of Campinas and Itú, the proportion of them who practice four-handed dentistry daily is low. Itú, Embú and Penápolis present high grade of expanded functions to auxiliary personnel in dental clinic activities. According to the auxiliary personnel, the aided population answer positively and accept their services well. Besides, dentists have a good or very good professional relationship with them, give them orientation everytime it is necessary; also, in their opinion, dentists ought to keep up the corrent level of supervision. 


\section{INTRODUÇÃO}

\subsection{Os recursos humanos no Sistema Único de Saúde}

O acontecimento reconhecido como mais importante na saúde pública mundial no presente século é o objetivo internacional de alcançar saúde para todos no ano 2000 , com base nas estratégias de atenção primária em saúde e de sistemas locais de saúde (SILOS) $11,25,33,35$.

A maioria dos paises têm aderido a esta estratégia que carrega em si, princípios de regionalização, descentralização e integração dos serviços. Através da articulação intersetorial e do trabalho com equipes interdisciplinares, busca-se permanentemente a promoção da saúde, a prevenção de enfermidades, o autocuidado e a participação comunitária na identificação de problemas e definição de prioridades 25,34 .

No Brasil, particularmente à partir dos anos 80 e da redemocratização do país, organismos estatais na área da saúde produziram proposiçøes de racionalização e de extensão da cobertura6,7,42 ao mesmo tempo em que teve impulso o desenvolvimento de redes básicas de saúde.

A multiplicação de movimentos sociais, entre eles, o de saúde, alavancou a luta por direitos, o exercício da cidadania e de construçøes políticas de envergadura histórica no campo da saúde conforme demonstra a realização das últimas conferências nacionais de saúde ${ }^{13,14,15}$.

A implementação do Programa de Açđes Integradas de Saúde, dos convênios de estruturação de Sistemas Unificados e Descentralizados de Saúde nos Estados e a criação, pelos constituintes, do Sistema Único de Saúde (SUS) sintetizam e expressam, conforme alguns analistas, as propostas políticas dos vários segmentos da sociedade brasileira em relação à questão da saúde-doença no país e confirmam o sentido de maior participação dos poderes locais nas decisర̋es sobre saúde 28 .

Deste modo, o SUS pode ser entendido como a estruturação de SILOS ou distritos sanitários ${ }^{34,35}$ em cada região ou município, segundo características demográficas e dos serviços de saúde de cada um desses locais. Os SILOS, portanto, podem ter variada abrangência geográfica e ora podem constituir-se em parte de um sistema municipal de 
saúde, ora confundir-se com o próprio sistema municipal e, algumas vezes, chegar a abranger mais de um municipio 40 .

A implementação de SILOS que respondam às necessidades da população implica, dentre outros aspectos, organizar uma rede básica de saúde que possa resolver $70 \%$ a $80 \%$ dos problemas de saúde-doença das pessoas que procuram o SUS. Além disso, cabe a esta rede participar de açôes intersetoriais e desenvolver açðes coletivas em saúde no interior de espaços e equipamentos sociais (centros comunitários, escolas, creches, fábricas, domicílios) na área de abrangência de cada unidade básica de saúde ${ }^{45}$.

A necessidade da universalidade de acesso aos serviços de saúde em todos os níveis de assistência e da integralidade, entendida como um conjunto articulado e contínuo das açóes e serviços preventivos e curativos, individuais e coletivos, exigidos para cada caso em todos os niveis de complexidade do sistema ${ }^{5}$, requerem a implementação de diferentes modalidades assistenciais.

Dentre elas, cabe destacar a assistência odontológica que combinada com as açóes coletivas em saúde bucal vem propiciando em cada SILOS, diferentes formas de organização da atenção à saúde bucal a fim de se cumprir os princípios e diretrizes previstos na Lei Orgânica do SUS 5 .

Sendo o setor saúde um setor de tecnologia trabalho-intensivo, a gestão dos recursos humanos tem dimensão estratégica na organização da atenção à saúde e no processo de estruturação dos SILOS. Além disto, os recursos humanos constituem importante área de estudo de pesquisadores em saúde pública.

Dentre inúmeros aspectos pode-se ressaltar sua relevância do ponto de vista econômico - cerca de $60 \%$ a $80 \%$ dos gastos com serviços de saúde são dispendidos na remuneração dos trabalhadores 30 - e sua importância do ponto de vista social e epidemiológico, isto é, os padróes de eficácia e de oferta de serviços em relação aos problemas de saúde de uma determinada população dependem em grande medida do perfil, do número e dos tipos de recursos humanos disponíveis num dado momento. 


\subsection{O pessoal auxiliar odontológico no SUS}

No campo da saúde bucal tem-se assistido nos últimos anos em determinados locais, a adoção de uma série de inovaçóes tecnológicas no modo de produzir, ofertar e estruturar serviços e açठes de atenção à saúde bucal.

Essas inovaçðes têm repercutido no nivel primário de atenção, na organização tanto das açð̋es coletivas como das açð̄es de assistência odontológica individual. Segundo vários analistas ${ }^{48}$, devem apontar no sentido da estruturação de sistemas de prevenção com base na associação de métodos preventivos e educativos e nos conhecimentos sociais e epidemiológicos, e no desenvolvimento de sistemas de trabalho de alta cobertura, com base em conhecimentos de ergonomia e de simplificação e racionalização do trabalho odontológico.

Admite-se que inúmeros fatores vem contribuindo para a introdução dessas modificaçठ̄es em serviços públicos odontológicos no Brasil. Dentre eles, pode-se destacar:

- os altos índices de prevalência da cárie dentária e das doenças periodontais, conferindo a estas, o estatuto de problemas de saúde pública;

- o desequilibrio entre a demanda e a oferta de serviços de assistência odontológica;

- o desenvolvimento científico-tecnológico no campo da ergonomia, cariologia e da epidemiologia, criando diferentes sistemas, métodos e técnicas de trabalho;

- a divisão técnica horizontal e vertical do trabalho odontológico ( especialistas e pessoal auxiliar ), incorporando diferentes sujeitos e alcançando maiores níveis de qualidade e produtividade;

- as proposiçóes de racionalização e extensão da cobertura através da estruturação de redes básicas de saúde implementadas no campo das políticas públicas de saúde;

- a multiplicação de movimentos por direitos sociais, entre eles, o direito à saúde, ampliando-se a participaçăo dos poderes locais nas decisరes sobre saúde.

Nesta investigação pesquisou-se parcela dos recursos humanos em saúde constituída pelo pessoal auxiliar odontológico ${ }^{8}$ (PAO) empregado na rede básica de 
serviços de dez sistemas locais de saúde do SUS, em cinco municipios do Estado de São Paulo, em 1994. Depreende-se, portanto, que tanto o técnico, quanto o auxiliar em prótese dentária, tipos de PAO que exercem suas atividades profissionais em ambientes denominados laboratórios de prótese dentária e que compठ́em os serviços de apoio terapêutico, não serão objeto desta pesquisa em particular.

O exame da literatura indica que o PAO começa a ser incorporado aos serviços a partir do início deste século nos Estados Unidos em 1913 com a utilização do "higienist"8, e na Nova Zelândia em 1920 com o "school dental nurse"19. A partir da metade deste século ganha volume o número de artigos e publicaçðes à respeito de PAO, ao mesmo tempo em que a Europa, a América Latina, e outras regiốes do mundo, começam a incorporar também, este tipo de pessoal nos serviços odontológicos.

No Brasil, a análise de fontes documentais permite situar a origem deste tipo de pessoal no Serviço Especial de Saúde Pública (SESP), em 1952. Na época, este tipo de pessoal recebeu a denominação de auxiliar de higiene dentária18,24. Merece relevância também, a utilização de PAO nas atividades do Programa Integrado de Saúde Escolar (1977), dirigido pelo Dr. Sérgio Pereira no Distrito Federal.

Do ponto de vista jurídico-normativo, em 1975 , a Câmara de $1^{\circ}$ e $2^{\circ}$ graus do Conselho Federal de Educação aprovou o Parecer 460 que dispðe sobre os cursos de formação de técnico em higiene dental (THD) e atendente de consultório dentário (ACD). Regulando o exercício destas profissర̋es, o Conselho Federal de Odontologia aprovou a Decisão 26/84 e a Resolução 155/85 modificada posteriormente pelas Resoluções 157/87 e $185 / 93$.

É portanto, no final da década dos 70 e início da década dos 80 que, em diferentes regið̋es do Brasil, os serviços públicos - tanto aqueles existentes quanto aqueles começando a se estruturar - passam a utilizar pessoal de nivel elementar e médio para auxiliar nas açðes de assistência odontológica. A participação do PAO deixa de localizar-se apenas em algumas instituiçoes, como por exemplo SESP e Instituto Nacional da Assistência Médica da Previdência Social (INAMPS), para expandir-se em direção a outras organizaçס́es públicas dos setores de saúde e de educação do pais. 
Cabe destacar que, se por um lado é razoável considerar que este processo está associado aos fatores anteriormente mencionados, por outro lado não se pode ignorar a intima relação com alguns aspectos da dinâmica do emprego em saúde no Brasil, dentre os quais, a evolução quali-quantitativa dos empregos e postos de trabalho em saúde e as tendências de segmentação e descentralização das políticas de contratação dos recursos humanos que se observa nesta época (1976-1984) 20.

Nesse periodo, registram-se vários embates e contendas sobre a necessidade da incorporação do PAO aos serviços públicos envolvendo distintos segmentos sociais, internos e externos à profissão odontológica, representativos enfim, consciente ou inconscientemente, de distintos interesses e projetos sanitários no campo da saúde pública em geral, e da saúde bucal em particular27.

A propósito, uma visão panorâmica da saúde bucal em diferentes partes do planeta ${ }^{37}$, permite admitir que a redução das principais doenças da boca pode ser mais facilmente alcançada em sociedades industrializadas que conseguem articular e conjugar as principais forças sociais do pais, na direção da implementação de projetos politicos que, no plano mais geral, respondam às exigências de desenvolvimento econômico, justiça social e democracia política, e no plano da saúde bucal, universalizam medidas coletivas relativas ao uso de flúor e incorporam PAO nos sistemas de saúde.

\subsection{Diretrizes de saúde bucal no SUS-SP}

Em 1989, aprovou-se no Estado de São Paulo, a Resolução CIS-SP $12 / 89$ instituindo o "Programa Estadual de Saúde Bucal - Diretrizes para os Programas Regionais e Municipais". Tal Resolução formalizou um conjunto de diretrizes para as ações na área de saúde bucal, cuja origem pode ser localizada nos anos que se seguiram à realização da primeira eleição direta para o Governo do Estado, em 1982, já num contexto de fím do Regime Autoritário. A partir de 1983 iniciou-se o processo de descentralizaçăo da assistência odontológica pública em São Paulo, com os convênios Estado-Prefeituras. Esses convènios tinham por finalidade, dentre outros aspectos, a fluoretação das águas de abastecimento público, a contrataçāo de cirurgiōes-dentistas, pessoal auxiliar e a montagem de clínicas odontológicas modulares. Esse processo culminou com a transferência da 
coordenação das açōes de saúde escolar da Secretaria de Estado da Educação para a Secretaria de Estado da Saúde, e na aprovação da Resolução CIS-SP 12/89 que direcionou as açठes de saúde bucal para um novo modelo assistencial. Pode-se admitir que buscou-se consolidar as propostas de alteraçoes nas práticas da odontologia em saúde coletiva na perspectiva da universalização da atenção à saúde bucal sob os princípios gerais do Sistema Único de Saúde ${ }^{43}$.

Destas diretrizes cabe destacar a prioridade para as açóes coletivas preventivas e educativas visando a promoção da saúde bucal e a reorganização do processo de trabalho odontológico com a incorporação e formação de pessoal auxiliar de niveis elementar e médio: auxiliares e técnicos em higiene dental.

Em nivel federal, durante a década dos 80 , algumas tentativas foram feitas no sentido da implementação de açōes preventivas, dentre as quais cabe destacar o Programa Nacional de Prevenção da Cárie Dentária (PRECAD) que propunha a expansão da fluoretação das águas de abastecimento público e a aplicação tópica semestral de gel fluorado em crianças em idade escolar.

Em 1991, através da Portaria 184, a Secretaria Nacional de Assistência à Saúde do Ministério da Saúde, instituiu na tabela de procedimentos do Sistema de Informaçסes Ambulatoriais (SIA-SUS), os procedimentos coletivos como atividades de caráter educativo e de proteção especifica à saúde bucal segundo très conjuntos de complexidade crescente:

- Procedimentos coletivos I: levantamento epidemiológico, educação em saúde, bochechos fluorados e higiene bucal supervisionada.

- Procedimentos coletivos II: PC I + exame clínico e terapêutica intensiva com flúor (géis, vernizes etc.).

- Procedimentos coletivos III: PC II + remoção de cálculos, aplicação de selantes e cariostáticos, escariação e selamento de cavidades e remoção de raizes residuais.

Em 1992, através da Resolução SS-13/92, a Secretaria de Estado da Saúde, normalizou os procedimentos coletivos da área de odontologia nos serviços de saúde integrantes do SUS-SP. 
Por ocasião da $1^{\text {a }}$ Conferência Municipal de Saúde Bucal, promovida em 1993 pela Secretaria Municipal de Saúde de São Paulo, reafirma-se que "os serviços no âmbito do município devem garantir a grupos populacionais prioritários, do ponto de vista social e epidemiológico, acesso a métodos preventivos de cárie dentária através de açóes coletivas", sendo que "os locais onde se desenvolverão as açठ̋es coletivas são institucionais como creches, pré-escolas, escolas e outros não institucionais como por exemplo fábricas, associaçóes de moradores, igrejas, etc.".

Nesse mesmo ano, na $2^{\text {a }}$ Conferência Estadual de Saúde Bucal promovida pelo SUS-SP, reitera-se que "as políticas de saúde bucal devem favorecer a transformação da prática odontológica, através da incorporação de pessoal auxiliar e de novas tecnologias, e o desenvolvimento de açóes coletivas de saúde, sem as quais não será possivel obter impacto na cobertura à população e nem alterar suas características epidemiológicas".

Todos estes aspectos confirmam e apontam para a necessidade da mudança do modelo de prática odontológica adotado no âmbito do Sistema Único de Saúde.

No Estado de São Paulo, embora inúmeros sistemas locais de saúde (SILOS) venham empregando $\mathrm{PAO}$, há pouca informação disponivel sobre a contribuição que estes trabalhadores tem dado às açôes de atenção à saúde bucal.

Que papel o PAO tém desempenhado para a mudança das características da prática odontológica nos serviços públicos? O PAO vêm sendo utilizado mais nas açôes de assistência odontológica individual ou nas açoes coletivas de saúde bucal ? Sua participação se dá mais em atividades educativas e preventivas de grupos sociais ou no apoio de atividades curativas realizadas em ambientes da clínica odontológica ? Como se distribuem as açoes e tarefas do PAO durante sua jornada de trabalho ? Esta distribuição depende do municipio ? Quais as características desses trabalhadores ?

Estas questరes podem traduzir problemas práticos, a serem enfrentados em cada SILOS mas, também, problemas mais gerais associados ao modelo de prática odontológica predominante no Brasil. 
As respostas a essas questð̃es permitem conhecer como as açס̄es previstas para serem desenvolvidas pelo PAO estão distribuidas ao longo do período de trabalho; se existe ênfase nas açðes coletivas ou nas açð̌es de assistência individual; e que açס̋es no campo da gestão dos recursos humanos e da coordenação das açôes de saúde bucal devem ser implementadas para uma participação social e epidemiologicamente mais eficaz.

A hipótese básica que orienta esta pesquisa é que a incorporação do PAO vem se dando em um modelo de prática odontológica caracterizado pela concentração das açớes no campo da assistência individual, isto é, na oferta de procedimentos cirúrgicorestauradores com base em instrumentos da clínica odontológica.

\section{REVISÃO DA LITERATURA}

A análise da literatura existente foi realizada com base em critérios de extensão e de conteúdo. Foi necessário restringir a consulta apenas a artigos e publicações em línguas de dominio do autor, isto é, portuguesa, inglesa e espanhola. Além disto, foram citados apenas os artigos divulgados nos últimos 15 anos que apresentavam maior proximidade ao campo de investigação em recursos humanos e aos propósitos da presente pesquisa.

Conforme já expresso anteriormente, a partir dos anos 50, cresceu bastante o volume de publicaçóes a respeito de PAO. Dentre os temas de maior interesse dos pesquisadores nas últimas décadas destacaram-se:

- educação e treinamento: apresentaçăo e discussão de programas de cursos de formação, treinamentos, requisitos para admissão e ingresso, carga horária, extensão e natureza dos conteúdos etc;

- legislação e jurisprudéncia: análises comparativas e sugestớes de mudança de legislação, pertinência e emprego da supervisão direta ou indireta, publicação de procedimentos e normas estabelecidos por organismos nacionais e conselhos locais etc;

- aspectos psicológicos: pesquisas sobre comportamento individual e coletivo em relação ao tabagismo, à higiene bucal, ao consumo de determinados produtos etc; 
- distribuição e oferta: levantamentos de pessoal auxiliar trabalhando junto à serviços públicos e privados, número de centros e escolas de formação, necessidades no momento atual etc;

- utilização: publicação de aspectos sobre a expansão de funçס̃es, delegação de atribuiçðes, experiências de paises, localidades, instituiçð̃es e serviços de pequeno porte etc;

- aspectos económicos: estudos de viabilidade econômica, percentuais de aumento de receita em consultórios particulares e de diminuição de relação custo-benefício nos serviços públicos, rendimentos médios de pessoal auxiliar, extensão da cobertura, maior ingresso de pacientes e melhoria do padrão de assistência etc;

- tendéncias: projeçōes e perspectivas, com base no processo histórico e em experiências de diferentes localidades, sobre a utilização e o desempenho futuro tanto do pessoal auxiliar quanto de serviços de saúde bucal.

Além deste fato, cabe ressaltar a expansão do PAO nos paises da América do Norte, que provocou um razoável desenvolvimento de associaçóes de classe, entidades, e artigos e publicaçठes sobre temas referentes a este tipo de pessoal. Apenas para ilustrar, em 1988, no $75^{\circ}$ aniversário da profissão dos higienistas dentais norte-americanos, o PAO nos EUA já contava com várias publicaçðes periódicas, mais de 200 mil profissionais entre assistentes, higienistas dentais (HD) e auxiliares de funçס̌es expandidas ${ }^{53}$, sendo que a primeira publicaçăo surgiu em 1927.

A seguir são apresentadas algumas pesquisas selecionadas conforme os critérios expostos.

TABACOF 49 ao estudar os recursos institucionais existentes na área odontológica em Salvador, BA, em 1973-74, encontrou uma relação favorável de 177 auxiliares para 305 cirurgióes-dentistas (CD). $47 \%$ dos auxiliares ganhava até um salário mínimo regional (SMR) e $77 \%$ até dois SMR.

BOTT14 ao efetuar um estudo no setor de prestação de serviços odontológicos em 1977 em Santa Maria,RS, encontrou que 20\% dos auxiliares recebiam menos de um 
SMR e $85 \%$ ganhavam no máximo dois SMR; $92 \%$ eram mulheres; $90 \%$ tinham pelo menos "curso ginasial incompleto"; sendo que $89 \%$ foram treinadas em serviço pelo próprio CD.

ROCK \& BRADNOCK ${ }^{39}$ estudaram o emprego de HD no Reino Unido. Dentre os dentistas que utilizavam produtos preventivos $(80 \%)$, cerca de $20 \%$ empregavam HD. Ao se estudar as atividades, verificou-se que somente $12,7 \%$ das aplicaçбes de gel fluorado e $6,3 \%$ das aplicaçōes de selante oclusal foram realizadas pelos $H D$, sugerindo que os dentistas delegavam para os HD mais atividades de raspagem e polimento coronário.

JANCZUK 22 estudando as atividades realizadas pelos HD na Polônia verificou que dos 157 que responderam ao questionário, 71 (45,2\%) comportavam-se como auxiliares odontológicos, 71 (45,2\%) realizavam atividades de educação em saúde bucal, 67 (42,6\%) atividades de profilaxia com flúor, $39(24,8 \%)$ atividades de tartarectomia e inserção de amálgama. Encontrou também que, das quarenta respostas à pergunta sobre se os pacientes reagiam positivamente às instruçסes dadas e aos procedimentos efetuados pelas higienistas, 36 indicaram que a reação era positiva e apenas 4 que era negativa.

NASH; DOUGLAS \& WILSON29 publicaram estudo em 1979 no qual indicam que, em prática privada nos EUA, HD gastaram 29,5 milhóes de horas por ano na prevenção e tratamento das doenças periodontais - mais do que gastaram periodontistas e clínicos gerais juntos: 2,9 milhoes e 17 milhరes de horas, respectivamente.

VASCONCELLOS 52 ao realizar revisão da literatura e estabelecer relaçбes entre necessidades e recursos na área da odontologia sanitária, propóe a utilização de um tipo de pessoal auxiliar - assistente odontológico - visando aumentar a produtividade da equipe de prestação de serviços, no campo de ação da dentística restauradora. Este profissional seria absorvido pelo setor público, para trabalhar sob supervisão do dentista.

LEITE \& PINTO23 ao fazer uma revisão sobre a legislação e a prática atual da odontologia no que se refere à incorporação e formação de recursos humanos auxiliares, destacam que, em pesquisa realizada junto a 36 auxiliares odontológicos de três instituiçóes do Distrito Federal, aproximadamente $80 \%$ dos respondentes preferiam um curso em serviço (qualificação) à um exame de suplência (prova). 
BADER e col. ${ }^{2}$ reportaram dados provenientes de 13 consultórios privados autônomos em Kentucky, EUA. A contribuição dos HD para o total da receita bem como para a produção, foi medido em "padrões de produção por minuto" e cobriu aproximadamente 12 meses de atividades em cada um dos 13 consultórios. O número médio de horas trabalhadas para os 13 consultórios foi cerca de 20 horas por semana, e os HD gastaram cerca de $2 / 3$ deste tempo executando procedimentos radiográficos e de higiene bucal.

SCHOU e col. 46 estudando os HD formados no período de 1972-82 na Dinamarca, mostrou que, dentre os $59 \%$ que ainda estavam trabalhando como HD, $50 \%$ estavam empregados no serviço odontológico infantil, 35\% estavam trabalhando na clínica privada, $7 \%$ estavam ensinando higiene dental, e $4 \%$ estavam desenvolvendo atividades em institutos e hospitais.

COHEN e col. ${ }^{10}$ enviaram questionário para $1301 \mathrm{HD}$ empregados em locais não tradicionais, isto é, asilos, prisర̋es, hospitais, escolas, centros de convivência. Com $84,3 \%$ de retorno, o estudo mostrou que as fontes de informação sobre a obtenção do emprego referiam-se à indicação de amigos, colegas e parentes; que os fatores mais frequentemente referidos pelos HD como importantes para a tomada de decisão de trabalhar num local não tradicional são a satisfação profissional, os desafios da ocupação, o aumento da flexibilidade no trabalho e os benefícios, apesar de os salários de HD em locais não tradicionais serem, geralmente, mais baixos que os da prática privada.

WALSH $^{54}$, ao rever estudos sobre aspectos administrativos da prática odontológica, refere que vários estudos têm demonstrado que os serviços de higiene bucal são menos remunerados que outros, e que os dentistas deveriam delegar essas funçбes quando possível. Um estudo demonstrou que o tempo de desempenho, assim como a delegaçăo de funçôes, influenciam na produtividade da prática e também refletem no conceito de cuidado odontológico. Alguns autores e estudiosos de prática administrativa indicaram que práticas gerenciais precárias, sem uma maior demanda de pacientes não viabilizam económicamente a contratação de um higienista, ao passo que em serviços com uma boa capacidade administrativa e com pressão da demanda, um higienista pode dar 
uma grande contribuição para o aumento da produtividade. A menor remuneração das atividades do higienista dental e a alta porcentagem de tempo requerida para prover uma profilaxia completa, uma ou duas vezes ao ano para cada paciente, tem levado vários autores a duvidar que dentistas possam ou devam eles mesmos prover esses serviços. Conforme a autora em tela, os dados apresentados nos estudos reportados foram insuficientes, no entanto, para sustentar conclusðes sobre a rentabilidade das atividades de higienistas na prática odontológica.

STEELE ${ }^{48}$, ao analisar questionários respondidos pela maioria dos enfermeiros dentais empregados no serviço odontológico estatal de Trinidad e Tobago, verificou que sua distribuição geográfica era desigual. A jornada de trabalho era dispendida mais no tratamento de crianças nas clinicas que na educação em saúde bucal em escolas. A maioria dos respondentes considerou que seu trabalho tem efeitos positivos na saúde bucal das crianças, referindo aumento da consciência em saúde bucal, maior aceitação do tratamento, melhora da higiene bucal e atribuiçāo de maior valor à saúde bucal por parte do público em geral. O problema que mencionaram com mais frequência foram as deficiências nas instalaçðes, equipo, abastecimento e manutenção.

UITENBROEK e col. 51 pesquisando a influência de HD na educação em saúde bucal de dois grupos de pacientes, um grupo que recebeu serviços de HD e outro que não os recebeu, mostraram resultados que indicam a influência positiva dos HD no conhecimento, motivação e autocuidado dos pacientes do primeiro grupo quando comparado com os do segundo grupo.

NARVAl e col. 27 publicaram artigo em 1990 em que foram analisados aspectos relativos ao técnico em higiene dental (THD), um tipo de pessoal auxiliar odontológico recentemente reconhecido no Brasil. Apresentaram o resultado de uma pesquisaparticipante desenvolvida no Estado de São Paulo durante 26 meses, entre outubro de 1986 e dezembro de 1988, onde conclue-se que: o THD é imprescindivel à prestação de serviços odontológicos no Brasil; tem situação funcional perfeitamente legalizada; não restringe o mercado de trabalho do cirurgião-dentista; tem sua formação profissional amparada $e$ 
regulamentada pelo sistema educacional; contribui para elevar a qualidade dos serviços prestados à população; e não deve ser confundido com o falso dentista ("prático").

DEAL ${ }^{16}$ após enviar, em outubro de 1987, um questionário de 13 páginas para 55 direçōes odontológicas, buscando informação sobre higienistas dentais (HD) empregados pelo Estado com o objetivo de documentar o papel e a extensão da sua participação em programas de saúde pública, verificou que das quarenta e oito (48) direçôes que responderam ao questionário, 37 empregavam HD em programas de saúde pública, sendo 21 (56\%) em serviços educativos, um (2\%) somente em serviços clínicos e cinco $(13 \%)$ em serviços educativos e clínicos. Nas 37 direçð̋es que empregavam HD, existiam 305 em tempo integral e 51 em tempo parcial, provendo serviços tradicionais de higiene bucal, programas educativos, ou ambos. Das 37 direçôes, 21 (56\%) têm oportunidades de progressão para HD definidas pelo título do posto; 11 (29\%) têm HD em posiçðes de supervisão; e 10 (27\%) têm HD em posiçőes de nivel de administração. Quatro (10\%) têm oportunidades de progressão em supervisão e administração. Destacou-se que do total de 305 posiçð̋es de tempo integral, somente 17 (5\%) eram em nivel administrativo e $27(8 \%)$, em nivel de supervisão, o que sugeriu que era limitado a ascenção na carreira. Um terço dos programas educativos referiam-se à escolas primárias, bochechos fluorados, e programas pré-escolares, portanto relacionados com o desenvolvimento da primeira infância e com áreas nas quais HD, costumeiramente, estão envolvidos, sendo que programas de câncer bucal são oferecidos por HD de 17 (45\%) direçઠ̋es. Os resultados indicaram, ainda, que existia uma marcada diferença no salário recebido pelos HD em cada uma das três áreas de serviços. HD que proveram serviços educativos ganhavam, em média, US\$ 1.661. Aqueles empregados em ambos os serviços, clínicos e educativos, ganhavam em média US $\$ 1.441$ por mês, sendo que aqueles que estavam empregados para oferecer serviços clínicos tradicionais receberam uma média mensal de US\$ 1.375. Salários foram menores para HD que trabalhavam em saúde pública, que aqueles de prática odontológica privada. Somente $61 \%$ tinham HD envolvidos em programas educativos de água fluoretada, o que é, segundo o autor, surpreendentemente baixo considerando os benefícios comunitários conhecidos da água fluoretada. 
CIRINCIONE \& WILS$^{9}$ estudando a participação de HD empregados em hospitais mostraram, dentre outros aspectos, que aproximadamente um terço dos hospitais com serviço odontológico dispunham de HD. Destes, cerca de 75,9\% empregavam HD em tempo integral (30 ou mais horas por semana). Mais de 50\% dos 594 HD pesquisados gastavam seu tempo principalmente em atividades de educação, de cuidado de pacientes internados e de atendimento domiciliar. Pouco mais de $30 \%$ exerciam atividades administrativas.

AXELSSON e col. ${ }^{1}$ com o objetivo de avaliar a prática clínica de HD suecas em serviços públicos (SP) e privados, de um total de 1857 questionários enviados, analisou $1399(75,3 \%)$. Os resultados permitiram concluir que $37,2 \%$ dos HD trabalham na prática privada (PP), 45,8\% em SP, 6,2\% em ambos, e 10,8\% em clínicas especializadas ou como professores. A maioria dos HD que trabalha em SP, o fazem em centros de educação maternal, infantil e escolas de nivel básico. Dos HD que responderam, 28,6\% trabalham 40 horas por semana; $20,9 \%, 30 \mathrm{hs} / \mathrm{sem}$; $11,2 \%, 35 \mathrm{hs} / \mathrm{sem}$. e 10,8\%, $20 \mathrm{hs} / \mathrm{sem}$. No momento do estudo $21,2 \%$ estavam afastados do trabalho devido a gestação ou licença-maternidade. Dos pacientes tratados pelos HD, $88,7 \%$ eram adultos: $99,5 \%$ na PP e $78,4 \%$ em SP. $42 \%$ dos HD foram treinados no periodo de 1980-84. A média de tempo de tratamento por consulta foi de 49,7 minutos na PP e $45 \mathrm{~min}$. em SP. Raspagem, alisamento radicular e remoção de excessos/saliências levaram $27 \mathrm{~min}$. por consulta na PP e $22 \mathrm{~min}$. em SP. Quanto aos métodos nos dois tipos de prática, não houve diferenças significativas em relação à exames, treinamento de autocuidado, limpeza dentária mecânica profissional, aplicaçāo tópica de flủor, e testes salivares e de microbiologia bucal. Quanto à modalidade de risco dos pacientes adultos, 45,1\% estavam em risco periodontal, $9,1 \%$ em risco de cárie e $34,6 \%$ em risco associado com higiene. A raspagem, o alisamento radicular e a remoção de excessos/saliências levou $28 \mathrm{~min}$. por consulta em pacientes de risco periodontal e 14 min. em pacientes de risco de cárie. 


\section{OBJETIVOS}

O presente estudo tem por objetivos:

3.1. Conhecer as características profissionais do pessoal auxiliar odontológico em dez sistemas locais de saúde de cinco municípios do Estado de São Paulo, em 1994.

3.2. Conhecer a participação do PAO nas açoes de saúde bucal oferecidas, distinguindo as atividades coletivas das de assistência individual.

3.3. Estimar o tempo da jomada de trabalho do PAO dispendido nas atividades coletivas e nas atividades de assistência individual.

3.4. Comparar e analisar os resultados obtidos em cada sistema local de saúde.

3.5. Oferecer sugestరes no campo da gestão de serviços odontológicos. 


\section{PROCEDIMENTOS METODOLÓGICOS}

\subsection{A natureza do objeto}

As características desses trabalhadores e as açøes de saúde bucal realizadas pelo PAO empregado na rede básica de serviços de saúde do SUS inscreve-se no campo de investigação dos recursos humanos em saúde.

Neste campo destacam-se duas abordagens teóricas: uma que informa o recurso humano como profissional de saúde, fundando-se na noção do trabalho em saúde como exercicio autônomo de profissð̄es, e outra como força de trabalho, cuja análise destaca o conjunto das determinaçð̃es sociais e econômicas da estrutura das sociedades 31,47 .

Do ponto de vista epistemológico, ambas constituem-se em apreensð̃es parciais da realidade dos recursos humanos em saúde, nas quais, ora se releva a dimensão de sujeito pleno da ação e, ora a dimensão de agente subordinado à organização social da produção e distribuição dos serviços.

Conforme SCHRAIBER 47 , pretende-se um ângulo distinto de apreensão, também parcial, da questão dos recursos humanos em saúde. Este ângulo apreende o objeto de estudo relevando precisamente o seu caráter de trabalhador em saúde.

Esta noçăo, que se deu durante a Reforma Sanitária na década dos 80 , está intimamente ligada à noção de processo de trabalho, e portanto só se realiza, só se qualifica no âmbito do trabalho. Esta noção emergente nega-se a resumir a tecnologia de trabalho em saúde à condição de seu agente e menos ainda reduzir esta última à especificidades da formação escolar, identificando o recurso humano-trabalhador como um dos constituintes do processo de trabalho em saúde que apresenta, necessariamente, uma dimensão técnica e social17.

Não se trata, portanto, de negar aspectos do profissionalismo dos trabalhadores em saúde, nem tampouco as características que adquirem sua disposição como força de trabalho em mercado. Trata-se sim, de compreender o estatuto de trabalhador em saúde, como epistemologicamente mais fecundo e produtivo, uma vez que, nem a noção de profissão cunhada no século XIX, nem o conceito de força de trabalho 
advindo da Economia Política podem informar adequadamente sobre a participação do PAO nos sistemas locais de saúde.

Neste sentido, a investigação das características e das açðes de saúde bucal realizadas pelo PAO foi desenvolvida a partir de um referencial teórico, no qual o objeto de pesquisa é constituído de um segmento dos trabalhadores da saúde, que por sua vez, são sujeitos coletivos portadores de práticas que interagem com outros sujeitos (administradores e usuários de serviços de saúde) na tarefa de responder às necessidades de saúde-doença das populaçð̃es.

Admite-se que a incorporação de novas práticas e rotinas em saúde dependem, dentre outros aspectos, da atuação de diferentes sujeitos coletivos. No caso das práticas da odontologia em saúde coletiva, jogam papel importante dentistas e auxiliares, dentre outros sujeitos.

Do exposto, considera-se que o PAO, também assume o caráter de sujeito coletivo no sentido atribuido por $\mathrm{SADER}^{41}$, "de uma coletividade onde se elabora uma identidade e se organizam práticas através das quais seus membros pretendem defender seus interesses e expressar suas vontades, constituindo-se nessas lutas.".

Com base neste referencial, decorreu a decisão de optar pela coleta de informaçð̃es junto ao próprio PAO empregado. A razão principal foi que este sujeito é compreendido, não como o ancoradouro de todo o problema da participação do PAO, mas sim como a parte relacionada mais diretamente ao problema da pesquisa, aquela que potencialmente detêm mais conhecimentos sobre as características do PAO e de sua participação no modelo de atenção à saúde bucal em sistemas locais de saúde.

\subsection{Tipo de estudo}

Dado os objetivos e a natureza do objeto da pesquisa, e conforme os recursos disponiveis, realizou-se um "survey" analítico cuja população de estudo, variáveis e hipóteses são descritas a seguir. 


\subsection{População de estudo}

Foram selecionados por conveniência do autor dez SILOS, situados em cinco municipios do Estado de São Paulo, Brasil, de modo a compor um conjunto com diferentes formas de utilização e participação do PAO nas açøes de saúde bucal. Em comum, os SILOS escolhidos apresentavam mais de cinco anos de emprego deste tipo de trabalhador. Os SILOS compreenderam: Penápolis, Itú, Embú, três (3) regiōes de Campinas e quatro (4) de São José dos Campos. No período da pesquisa, estes SILOS empregavam, em conjunto 325 trabalhadores em funçø̋es auxiliares na área de saúde bucal.

Antes da descrição das variáveis e hipóteses, são apresentadas algumas características dos municípios onde se localizam os SILOS abordados, conforme informações constantes nos seus respectivos Planos Municipais de Saúde.

\subsection{Caracterização dos municipios}

\subsubsection{Itủ}

O municipio de ltú ocupa uma área de $642 \mathrm{Km}^{2}$ por onde distribuem-se 106.972 habitantes, segundo dados do censo de 1991. Localiza-se à $40 \mathrm{Km}$ da cidade de Sorocaba e faz limites com os seguintes municipios: Porto Feliz, Elias Fausto, Salto, Itupeva, Indaiatuba, Cabreúva, São Roque, Mairinque, além de Sorocaba.

Economicamente desenvolve as atividades no setor primário de hortícola e oleiricola, com predominância na produção de tomates e legumes. Fruticultura baseada na produção de uvas, morangos, pêssegos e citricos, e na agricultura básica com produção de cereais, cana-de-açúcar, café e batata inglesa. Na pecuária destaca-se a produção leiteira, a avicultura, suinocultura e a equinocultura. No setor secundário, predominam indústrias cerâmicas, participando ainda indústrias de brinquedo e metalúrgica. $O$ setor terciário desenvolve-se através do incentivo ao turismo na região que é favorecido pelas tradiçøes históricas do municipio.

A taxa de urbanização cresceu de $51,5 \%$ nos anos 40 para $90,35 \%$ em 1991. A taxa de natalidade foi de 8,6 nascidos vivos por 1000 habitantes em 1993. Dos 106.972 habitantes, $32,8 \%$ situavam-se entre $0-14$ anos, $52,7 \%$ entre $15-50$ anos e $14,4 \%$ com 50 
anos ou mais. A cobertura de água tratada chegava a $100 \%$ da população urbana e o acesso à rede de esgotos alcançava cerca de $96 \%$ dos habitantes. Apresentava uma relação cirurgiāo-dentista (CD) / PAO de 1:4.

\subsubsection{Embú}

O município de Embú situa-se a $30 \mathrm{Km}$ da cidade de São Paulo. Faz parte da região metropolitana tendo como limites os municipios de Itapecerica da Serra, Taboão da Serra, Cotia e Embú-Guacú. Sua população é estimada em 200.000 habitantes, com $31,8 \%$ entre 0-14 anos.

Do ponto de vista econômico predominam as atividades no setor terciário, sendo considerada "cidade-dormitório" por sua proximidade com a capital.

É uma regiăo de topografia acidentada e as condiçōes de saneamento básico são muito precárias. Grande parte da população vive em morros, muitas vezes em construçర̃es clandestinas de difícil acesso, tornando a distribuição de água deficiente. $O$ Plano Municipal de Saúde considerava que $95 \%$ da população tinha acesso relativo e irregular à água tratada e $15 \%$ das casas eram atingidas pela rede de esgotos. Apresentava uma relação de $C D / P A O$ de 1:2.

\subsubsection{Penápolis}

O município de Penápolis, situado à noroeste do Estado de São Paulo, dista aproximadamente $500 \mathrm{Km}$ da capital. Abrange uma área de $654 \mathrm{~km}^{2}$ e faz limites com Avanhandava, Alto Alegre, Barbosa, Braúna, Luiziânia e Glicério.

Conforme o censo de 1991 , possui 48.088 habitantes, sendo $88,2 \%$ na zona urbana e $11,8 \%$ na zona rural. É observada uma taxa de natalidade de $17,7 \%$.. A atividade econômica básica é a agro-pecuária. Apresentava uma relação de CD/ PAO de 1:5.

\subsubsection{São José dos Campos}

O município de São José dos Campos localiza-se na região do Vale do Paraiba, leste do Estado de São Paulo e distante $84 \mathrm{Km}$ da capital. Possui uma área de $1.118 \mathrm{Km}^{2}$ onde vivem, segundo dados do censo de 1991, 442.728 habitantes. Faz divisa 
com os municipios de Camanducaia, sapucaí Mirim, Jacareí, Jambeiro, Caçapava, Monteiro Lobato. Iaaratá, Joanópolis e Piracaia.

O setor secundário da economia é predominante com indústrias de médio e grande portes nos ramos de transporte, química, comunicação, material bélico, mecânica, dentre outros. Em 1991, a Secretaria Municipal de Planejamento informava a presença de cerca de 628 indústrias instaladas gerando mais de 60.000 empregos. Na agricultura destaca-se a pecuária leiteira, a rizicultura e mais recentemente o reflorestamento com eucaliptos destinados à indústria de papel e celulose.

A taxa de urbanização era estimada em cerca de $98 \%$. Dos 442.728 habitantes, estima-se que $35 \%$ situavam-se entre $0-14$ anos, $54 \%$ entre $15-50$ anos e $11 \%$ com 50 anos ou mais. Populaçóes de alguns bairros mais periféricos não tinham acesso à rede de água e esgoto. O sistema municipal de saúde é dividido em quatro regióes: sul, norte, leste e centro. Apresentava uma relação CD/PAO de 1:1,7.

\subsubsection{Campinas}

Situada à $100 \mathrm{Km}$ ao norte da capital do Estado, Campinas ocupa lugar de destaque com sólido parque industrial e diversificado setor de serviços. Junto com 18 municípios da região, detêm o maior setor terciário do interior do Estado de São Paulo, à frente de diversas áreas metropolitanas brasileiras.

Resultado preliminares do censo de 1991, indicam uma população predominantemente urbana, constituída de 846.38 habitantes, dos quais $29,6 \%$ entre $0-14$ anos, $55,4 \%$ entre $15-50$ anos e $15 \%$ com 50 anos ou mais. O grau de urbanização em 1981 era de $97,5 \%$. Aproximadamente $98 \%$ da população dispunha de água tratada e $86 \%$ de esgoto sanitário. Existiam regiôes significativas sem acesso à rede de água. $\mathrm{O}$ sistema municipal de saúde é dividido em quatro regióes: leste, oeste, norte e sul. Apresentava uma relação de CD/ PAO de 1:0,8 


\subsection{Variáveis}

As variảveis foram de duas ordens de interesse: uma referente às características desses trabalhadores e outra referente à participação nas açбes de saúde bucal desenvolvidas.

Na primeira incluiu-se: município e SILOS onde trabalha, sexo, idade, função que exerce, vinculo empregatício, jornada de trabalho, salário, escolaridade, formação profissional e local de trabalho, isto é, unidade de saúde ou unidade escolar.

$\mathrm{Na}$ segunda referiu-se a participação nas açסes de saúde bucal desenvolvidas, distinguindo-se as açסes segundo sua natureza, isto é, no campo das açठes coletivas com grupos de crianças, adolescentes ou adultos; e no campo das açoes relacionadas com a assistência individual, e portanto, realizadas na clínica odontológica. Além disso, as açðes individuais foram subdivididas conforme o profissional auxiliar que a exerce. Neste sentido, as açð̌es foram classificadas em três categorias:

1. Açð̃es coletivas, em que se destacam: atividades preventivas com grupos (evidenciação de placa, escovação supervisionada, bochechos fluorados, aplicação tópica de flúor com escova ou moldeira ) e atividades educativas ou orientação com grupos de pessoas (trabalho em grupo, palestra, aula, reunião).

2. Ações de assistência individual exercidas por ACDs ou também denominadas de procedimentos de apoio na assistência individual (clínica): preparação do ambiente odontológico, limpeza e desinfecção de materiais, esterilização de instrumentos, preparação de materiais forradores e restauradores, e instrumentação.

3. Açőes de assistência individual exercidas por THDs: de caráter preventivo: aplicação tópica de flúor, selante ou cariostático com sucção de campo, polimento coronário; e de caráter curativo: remoção de indutos e cálculos salivares, inserção de materiais resturadores provisórios ou definitivos.

Em relação às açðes coletivas, importou também conhecer a frequência de realização das açōes e o número de pessoas beneficiadas. 


\subsection{Hipóteses}

As hipóteses foram enunciadas nos seguintes termos:

$H_{1}$ : A proporção estimada de tempo da jornada de trabalho do PAO na execução de atividades ou procedimentos coletivos é menor que a proporção de tempo dedicada às atividades ou procedimentos individuais.

$\mathrm{H}_{2}$ : A proporção estimada de tempo da jornada de trabalho do PAO na execução de atividades ou procedimentos coletivos é influenciada pelo SILOS que emprega o PAO.

\subsection{A construção do questionário}

$\mathrm{Na}$ medida em que os dados a serem levantados eram basicamente dados factuais, diretos, limitados em sua abrangência e cujas respostas potencialmente apresentavam margem mínima de flexibilidade ${ }^{21}$ adotou-se um instrumento de observação indireta, do tipo questionário.

Com a finalidade de elaborar o instrumento de coleta de dados, durante a fase de planejamento da pesquisa, realizou-se estudo exploratório*. Com tal procedimento, pretendeu-se controlar a subjetividade do pesquisador e evitar o aparecimento de vício ou viés no instrumento de observação da realidade.

O estudo exploratório desempenhou papel fundamental no processo da pesquisa, na medida em que permitiu a construção de um instrumento de pesquisa adequado, isto é, compativel com o repertório de conhecimentos e experiências dos informantes.

" Método preconizado por PIOVESAN, A. Disciplina de Metodologia de Pesquisa em Saúde, Faculdade de Saúde Pública da Universidade de São Paulo. 
De início, seis entrevistas com trabalhadores em funçðes auxiliares de serviços públicos odontológicos foram realizadas. Conforme PIOVESAN, partiu-se de questões gerais e básicas, como por exemplo:

- que atividades você desenvolve?

- que tipo de serviço você faz?

- o quê você gosta no trabalho?

- como é o seu trabalho no dia a dia?

- qual sua expectativa em relação ao trabalho?

Em seguida, as gravaçð̃es foram transcritas e estudadas com a finalidade de identificar a necessidade de correçôes para melhorar a técnica da entrevista, as áreas de interesse e os temas e termos de maior familiaridade do PAO. Realizou-se mais quatro entrevistas em profundidade em que foram acrescentados aos anteriores os seguintes temas:

- como é o trabalho dentro da unidade de saúde e fora da unidade de saúde ?

- quanto tempo fica na atividade de escovação e quanto junto ao dentista?

- todos os pacientes agendados passam pela atividade de escovação?

- você faz atividade com grupos de pacientes?

- o que você fala na palestra?

- como tem sido a resposta da população às suas orientações ?

- como é a relação com a equipe de saúde bucal, com os dentistas por exemplo ?

As entrevistas, novamente, foram gravadas e transcritas. Um vez analisadas, foram identificados seis temas de interesse, e iniciou-se a elaboração do questionário contemplando aspectos relacionados às seguintes características:

- demográficas;

- da escolaridade e formação profissional;

- do vínculo empregatício;

- da participação na assistência odontológica individual;

- da participação em açóes coletivas; $e$

- da opinião do PAO. 
Em seguida, o questionário foi testado com um grupo de 20 auxiliares para se verificar a compreensão das questôes, a clareza e a objetividade dos termos utilizados. Uma vez procedidas as alteraçбes julgadas necessárias, o questionário foi pré-codificado para permitir a transferência direta dos dados para o software, alcançando a formatação final conforme o modelo em anexo.

\subsection{Coleta dos dados}

Contatos foram realizados com cada SILOS a fim de possibilitar uma reunião com o conjunto do PAO empregado no nível primário de atenção. Definiu-se que a coleta dos dados deveria ser realizada num período típico de atuação. Considerou-se como periodo típico os meses de março, abril, maio, junho, agosto, setembro, outubro, ou novembro. Excluiram-se os demais meses por não haver coincidência com rotinas de certos espaços sociais como por exemplo escolas, local preferencial para o desenvolvimento de açðes coletivas em saúde.

Na reunião com auxiliares de cada SILOS, foram apresentados os objetivos e os critérios da pesquisa a fim de minimizar eventuais dificuldades de preenchimento do instrumento e assegurar a motivação do informante ${ }^{28}$. Deste modo, procurou-se garantir a validade e consistência da pesquisa e assegurar, por parte do informante, isenção, fidedignidade, e estrita observância dos critérios.

Os questionários eram distribuídos e após o preenchimento cada respondente entregava e aguardava a conferência por parte do aplicador. Esta conferência consistiu na observação se todos os quesitos foram lidos, a fim de se evitar que eventuais ausências de resposta fossem por motivo inconsciente, ignorado ou involuntário. Nesta etapa, algumas vezes o respondente solicitou que se confirmasse o atendimento ou não dos critérios previamente anunciados, e por vezes voltava para completar o preenchimento.

Concluída a coleta de dados, os questionários foram numerados, codificados e tabulados, utilizando-se o software DBASE III PLUS e obtendo-se um arquivo com os dados coletados. Ao final do processo, 248 questionários foram preenchidos e tabulados, sendo excluídos 3 por não observância dos critérios estabelecidos. 


\subsection{Análise dos dados}

Para a maioria das variáveis efetuou-se estatística descritiva envolvendo elaboração de frequências e cálculos de percentuais. Para as variáveis quantitativas, salário e número de pessoas beneficiadas, foram calculadas médias e desvios-padrão. Os dados foram apresentados sob a forma de tabelas e gráficos. Utilizou-se como meio auxiliar o programa de análise estatística e epidemiológica EPI-INFO.

Para o cálculo do número de horas-trabalho por mês do PAO em cada SILOS, desprezou-se jornadas de trabalho em pronto-socorros, laboratórios de prótese, unidades volantes tipo "perua Kombi" e em atividades administrativas.

Para o cálculo da proporção de horas-trabalho por mês em açóes coletivas foram realizadas cinco operaçð̋es matemáticas.

Como primeira operação, para cada tipo de ação coletiva e de local de realização, foi extraído o número de pessoas beneficiadas por mês. Para a ação bochechos fluorados este dado foi obtido através da multiplicação da frequência por semana pelo total de pessoas em cada vez. Para as demais açoes, o número de pessoas beneficiadas por mês foi calculado de acordo com a periodicidade ou frequência com que o trabalhador declarou realizar a ação coletiva. No quadro a seguir é ilustrado o cálculo do número de pessoas beneficiadas por mês conforme a declaração de frequência por semana (a), por mês (b) e por ano (c).

(a) $N^{\circ}$ PESS. BENEFICIADAS $=\left(n^{\circ}\right.$ de vezes por semana $\left.X 4\right) \times$ total de pessoas em cada vez

(b) $N^{\circ}$ PESS. BENEFICIADAS $=\left(n^{\circ}\right.$ vezes por mês $) X$ total de pessoas em cada vez

(c) $N^{\circ}$ PESS. BENEFICIADAS $=\left(n^{\circ}\right.$ vezes por ano: 12$) \times$ total de pessoas em cada vez

A segunda operação foi o cálculo da média de pessoas beneficiadas mensalmente por auxiliar que declarou realizar a atividade e o respectivo desvio-padrăo.

A terceira operação foi o cálculo do número de horas por mês dispendidas por auxiliar em cada tipo de ação coletiva e local de realizaçăo. Nesta operação foi necessário 
criar e utilizar parâmetros de rendimento médio para uma auxiliar de jornada de 40 hs/semana, segundo o tipo de ação e o local de realização, conforme o seguinte quadro:

\section{PARÂMETROS DE RENDIMENTO MÉDIO}

\begin{tabular}{|l|c|c}
\hline \multirow{2}{*}{ TIPO DE AÇÃo } & \multicolumn{2}{|c}{ LOCAL DE REALIZAÇÃO DA AÇÃO } \\
\cline { 2 - 3 } & $\begin{array}{c}\text { escolas e outros espaços } \\
\text { sociais }\end{array}$ & $\begin{array}{c}\text { unidades básicas de } \\
\text { saúde }\end{array}$ \\
\hline $\begin{array}{l}\text { Bochechos fluorados } \\
\begin{array}{l}\text { Evidenciação de placa } \\
\text { bacteriana seguida de } \\
\text { escovação supervisionada }\end{array}\end{array}$ & $\begin{array}{c}125 \text { por hora } \\
\text { Aplicação de flúor com } \\
\text { escova ou moldeira }\end{array}$ & 15 por hora \\
Atividades educativas & 40 por hora & 3 por hora \\
\hline
\end{tabular}

Estes parâmetros foram elaborados a partir de informações de coordenadores e supervisores de ações coletivas em saúde bucal relatadas ao autor. As diferenças entre os parâmetros dos dois tipos de local justificam-se em função das características de estrutura fisica que geralmente os dois tipos de local apresentam.

Em seguida, foi calculado para cada ação coletiva, o número de horas dispendido por mês pelo total de auxiliares de cada SILOS.

A quinta e última operação foi o cálculo do tempo total dispendido em açס̃es coletivas obtido através da soma do tempo dispendido por mês nas atividades de bochechos fluorados, evidenciação de placa bacteriana seguida de escovação supervisionada e aplicação de flúor com escova ou moldeira. Desprezou-se o tempo dispendido nas orientaçठes coletivas por admitir-se este tempo já incluido nas atividades coletivas consideradas.

Com estes procedimentos foi possivel verificar a distribuição estimada do tempo da iornada de trabalho do PAO dispendida em atividades coletivas, sendo 
consideradas o restante participação em atividades relacionadas à assistência odontológica individual.

Importante assinalar que, no momento da pesquisa, não existiam no país estudos de rendimento para os diferentes tipos de atividades coletivas utilizando critérios semelhantes ou que pudessem servir de parâmetros para as operações descritas anteriormente. Nesse sentido, esses parâmetros foram criados somente para permitir a comparação da participação do PAO nas açб̃es de saúde bucal dos dez SILOS, produzindo-se inferências apenas com validade interna ${ }^{26}$. 


\section{RESULTADOS}

Dos 325 trabalhadores empregados em funçð̄es auxiliares na área de saúde bucal dos dez SILOS, 248 responderam ao questionário. Como 3 questionários foram excluídos, os dados coletados referem-se a 245 trabalhadores, 153 que declararam exercer funçð̋es de atendente de consultório dentário e 92 que declararam exercer funçð̄es de técnico em higiene dental distribuídos pelos SILOS conforme a tabela 1.

\section{TABELA 1}

Distribuição do pessoal auxiliar odontológico empregado, e que respondeu ao questionário segundo a função que exerce e o sistema local de saúde pesquisado,1994.

\begin{tabular}{ccccccc}
\hline & \multicolumn{7}{c}{ FUNÇÃO } \\
\cline { 2 - 7 } SILOS & E & ACD & $\%$ & E & N & $\%$ \\
\hline Itú & 40 & 31 & 77,5 & 7 & 7 & 100,0 \\
Embú & 21 & 13 & 61,9 & 13 & 10 & 76,9 \\
Penápolis & 12 & 11 & 91,7 & 7 & 6 & 85,7 \\
SJCampos/Centro & 21 & 16 & 76,2 & 21 & 14 & 66,6 \\
SJCampos/Norte & 11 & 10 & 90,9 & 12 & 8 & 66,6 \\
SJCampos/Sul & 17 & 14 & 82,4 & 33 & 26 & 78,7 \\
SJCampos/Leste & 9 & 6 & 66,7 & 22 & 21 & 95,4 \\
Campinas/Oeste & 46 & 25 & 54,3 & - & - & - \\
Campinas/Leste & 17 & 15 & 88,2 & - & - & - \\
Campinas/Norte & 16 & 12 & 75,0 & - & - & - \\
\hline TOTAL & 210 & 153 & 72,9 & 115 & 92 & 80,0 \\
\hline
\end{tabular}

$E:$ número do pessoal empregado ( $E=325$ )

$\mathrm{N}$ : número do pessoal que respondeu ao questionário $(\mathrm{N}=245)$

A seguir, são apresentados os resultados relativos às características demográficas, da escolaridade, do vínculo empregatício, da participação em açốes coletivas, da participação na assistência individual, e da opinião do pessoal auxiliar. 


\subsection{CARACTERISTICAS DEMOGRÁFICAS}

As tabelas 2 e 3 mostram que o PAO é, em sua maioria, do sexo feminino e predominantemente jovem, pois cerca de $80,0 \%$ possui entre 17 e 37 anos de idade. Não foram observadas diferenças importantes entre os municipios e SILOS. Dois respondentes não declararam a idade.

\section{TABELA 2}

Distribuição da população de estudo segundo o sexo, 1994.

\begin{tabular}{ccc}
\hline SEXO & $f$ & $\%$ \\
\hline feminino & 227 & 92,7 \\
masculino & 18 & 7,3 \\
\hline Total & 245 & 100,0 \\
\hline
\end{tabular}

\section{TABELA 3}

Distribuição da população de estudo segundo a idade, 1994.

\begin{tabular}{ccc}
\hline IDADE & $f$ & $\%$ \\
\hline $17+--+23$ & 50 & 20,6 \\
$24+--+26$ & 50 & 20,6 \\
$27+--+31$ & 51 & 21,0 \\
$32+\cdots+37$ & 44 & 18,1 \\
$38+--+53$ & 48 & 19,7 \\
\hline Total & 243 & 100,0 \\
\hline
\end{tabular}




\subsection{CARACTERISTICAS DA ESCOLARIDADE}

Do ponto de vista da escolaridade, cerca de $95 \%$ do PAO tem pelo menos o $1^{\circ}$ grau completo, e quase $70 \%$ já terminou o $2^{\circ}$ grau (tabela 4 ).

\section{TABELA 4}

Distribuição da população de estudo segundo o grau de escolaridade e o município. 1994.

\begin{tabular}{|c|c|c|c|c|c|c|c|c|c|c|}
\hline \multirow[b]{4}{*}{ MUNICIPIO } & \multicolumn{8}{|c|}{ ESCOLARIDADE } & \multirow{2}{*}{\multicolumn{2}{|c|}{ TOTAL }} \\
\hline & \multicolumn{4}{|c|}{$1^{\circ} \mathrm{grau}$} & \multicolumn{4}{|c|}{$2^{\circ} \mathrm{grau}$} & & \\
\hline & \multicolumn{2}{|c|}{ incompleto } & \multicolumn{2}{|c|}{ completo } & \multicolumn{2}{|c|}{ incompleto } & \multicolumn{2}{|c|}{ completo } & \multirow[b]{2}{*}{$\mathrm{N}$} & \multirow[b]{2}{*}{$\%$} \\
\hline & $f$ & $\%$ & $f$ & $\%$ & $f$ & $\%$ & $f$ & $\%$ & & \\
\hline Itú & 5 & 13,2 & 4 & 10,5 & 8 & 21,1 & 21 & 55,2 & 38 & 100,0 \\
\hline Embú & - & - & 3 & 13,0 & 3 & 13,0 & 17 & 74,0 & 23 & 100,0 \\
\hline Penápolis & - & - & - & - & 2 & 11,8 & 15 & 88,2 & 17 & 100,0 \\
\hline SJCampos & 3 & 2,6 & 6 & 5,2 & 17 & 14,8 & 89 & 77,4 & 115 & 100,0 \\
\hline Campinas & 3 & 5,8 & 13 & 25,0 & 9 & 17,3 & 27 & 51,9 & 52 & 100,0 \\
\hline TOTAL & 11 & 4,5 & 26 & 10,6 & 39 & 15,9 & 169 & 69,0 & 245 & 100,0 \\
\hline
\end{tabular}

Em relação à formação profissional, $61,4 \%$ dos que exercem funçð̋es de ACD e $25 \%$ dos que exercem funçðes de THD, declararam possuir curso de formação profissional.

$\mathrm{Na}$ tabela 5, verifica-se que o municipio de Embú apresenta maior percentual de PAO com formação profissional, cerca de $90 \%$, seguido pelos municipios de Penápolis, Itú e Campinas com aproximadamente $70 \%$. Especificamente entre os THDs, é baixa a frequência de formação profissional, porque dos municipios que possuem PAO que declararam exercer funçôes de THD, S. José dos Campos não apresentou nenhum com curso de formação, influenciando para baixo o resultado, uma vez que $75 \%$ dos THDs 
pesquisados trabalham neste municipio. Desconsiderando este municipio, observa-se que $100 \%$ dos que exercem funçð̋es de THD, possuem curso de formação profissional.

Interessante citar que 3 trabalhadores exercendo funçס̆es de ACD em Itú e 2 na mesma condição em Campinas, declararam possuir curso de formação de técnico em higiene dental.

\section{TABELA 5}

Distribuição da população de estudo segundo a função exercida e a realização de curso de formação profissional por município, 1994.

\begin{tabular}{|c|c|c|c|c|c|c|c|c|c|}
\hline \multirow[b]{3}{*}{ MUNICÍPIO } & \multicolumn{6}{|c|}{ FUNÇÃO } & \multirow{2}{*}{\multicolumn{3}{|c|}{$A C D+T H D$}} \\
\hline & \multicolumn{3}{|c|}{$A C D$} & \multicolumn{3}{|c|}{ THD } & & & \\
\hline & $N$ & $f$ & $\%$ & $N$ & $f$ & $\%$ & $N$ & $f$ & $\%$ \\
\hline Itú & 31 & 22 & 71,0 & 7 & 7 & 100,0 & 38 & 29 & 76,3 \\
\hline Embú & 13 & 11 & 84,6 & 10 & 10 & 100,0 & 23 & 21 & 91,3 \\
\hline Penápolis & 11 & 6 & 54,5 & 6 & 6 & 100,0 & 17 & 12 & 70,6 \\
\hline SJCampos & 46 & 20 & 43,5 & 69 & - & - & 115 & 20 & 17,4 \\
\hline Campinas & 52 & 40 & 76,9 & - & - & - & 52 & 40 & 76,9 \\
\hline TOTAL & 153 & 99 & 64,7 & 92 & 23 & 25,0 & 245 & 122 & 49,8 \\
\hline
\end{tabular}

Quanto às respostas das perguntas se está ou não fazendo curso de ACD ou THD, destacou-se o PAO dos municípios de Itú e Campinas, em que $77,7 \%$ e $41,6 \%$, respectivamente, estavam fazendo ou curso de ACD ou de THD. No município de S. José dos Campos, $17,9 \%$ do PAO estava fazendo um dos dois cursos. Embú e Penápolis apresentavam 2 e 5 trabalhadores respectivamente, que não tinham curso de qualificação nem o estavam fazendo (tabela 6). 


\section{TABELA 6}

Frequência do pessoal auxiliar que declarou estar realizando curso de formação de ACD ou de THD por município, 1994.

\begin{tabular}{cccc}
\hline \multicolumn{2}{c}{ MUNICIPIO } & $\mathrm{f}$ & $\%$ \\
\hline Itú & $(\mathrm{N}=9)$ & 7 & 77,7 \\
Embú & $(\mathrm{N}=2)$ & - & - \\
Penápolis & $(\mathrm{N}=5)$ & - & - \\
SJCampos & $(\mathrm{N}=95)$ & 17 & 17,9 \\
Campinas & $(\mathrm{N}=12)$ & 5 & 41,6 \\
\hline
\end{tabular}

$\mathrm{N}$ : número de pessoal auxiliar sem curso de formação

A tabela 7 mostra que era significativo o valor do percentual de interesse do PAO de todos os municípios, em participar de cursos de formação de ACD ou THD, indicando que a formação e desenvolvimento dos trabalhadores pode ser uma atividade da área de recursos humanos com forte grau de adesão.

\section{TABELA 7}

Número e percentual do pessoal auxiliar que tem interesse em fazer curso de ACD ou de THD segundo o município. 1994

\begin{tabular}{crrc}
\hline & & \multicolumn{2}{c}{ INTERESSE EM CURSO } \\
\cline { 3 - 4 } MUNICíPIO & $\mathrm{N}$ & $\mathrm{f}$ & $\%$ \\
\hline Itú & 38 & 13 & 34,2 \\
Embú & 23 & 8 & 34,8 \\
Penápolis & 17 & 8 & 47,1 \\
SJCampos & 115 & 92 & 80,0 \\
Campinas & 52 & 46 & 88,5 \\
\hline TOTAL & 245 & 167 & 68,2 \\
\hline
\end{tabular}




\subsection{CARACTERISTICAS DO VINCULO EMPREGATICIO}

Quanto ao vínculo empregatício, 96,7\% dos que exercem funçðes de THD e $98,7 \%$ dos que exercem funçðes de $A C D$, tinham a administração pública municipal como empregadora

Em relação à jornada de trabalho, $100 \%$ dos que exercem funçðes de THD e $96,1 \%$ dos que exercem funçðes de $A C D$, responderam que tem vínculo correspondente a 40 horas semanais. Dentre os que declararam não ter jornada de 40 horas semanais, 1 tem jornada de 20 horas/semana e 5, 30 horas/semana, todos no SILOS oeste de Campinas.

A variação do salário recebido é maior entre os ACDs que entre os THDs, conforme revela o gráfico 1 . Entre os municípios, Penápolis e Itú propiciavam menor remuneração, sendo que Campinas e $\mathrm{S}$. José dos Campos apresentavam maiores médias salariais entre o PAO.

\section{GRÁFICO 1}

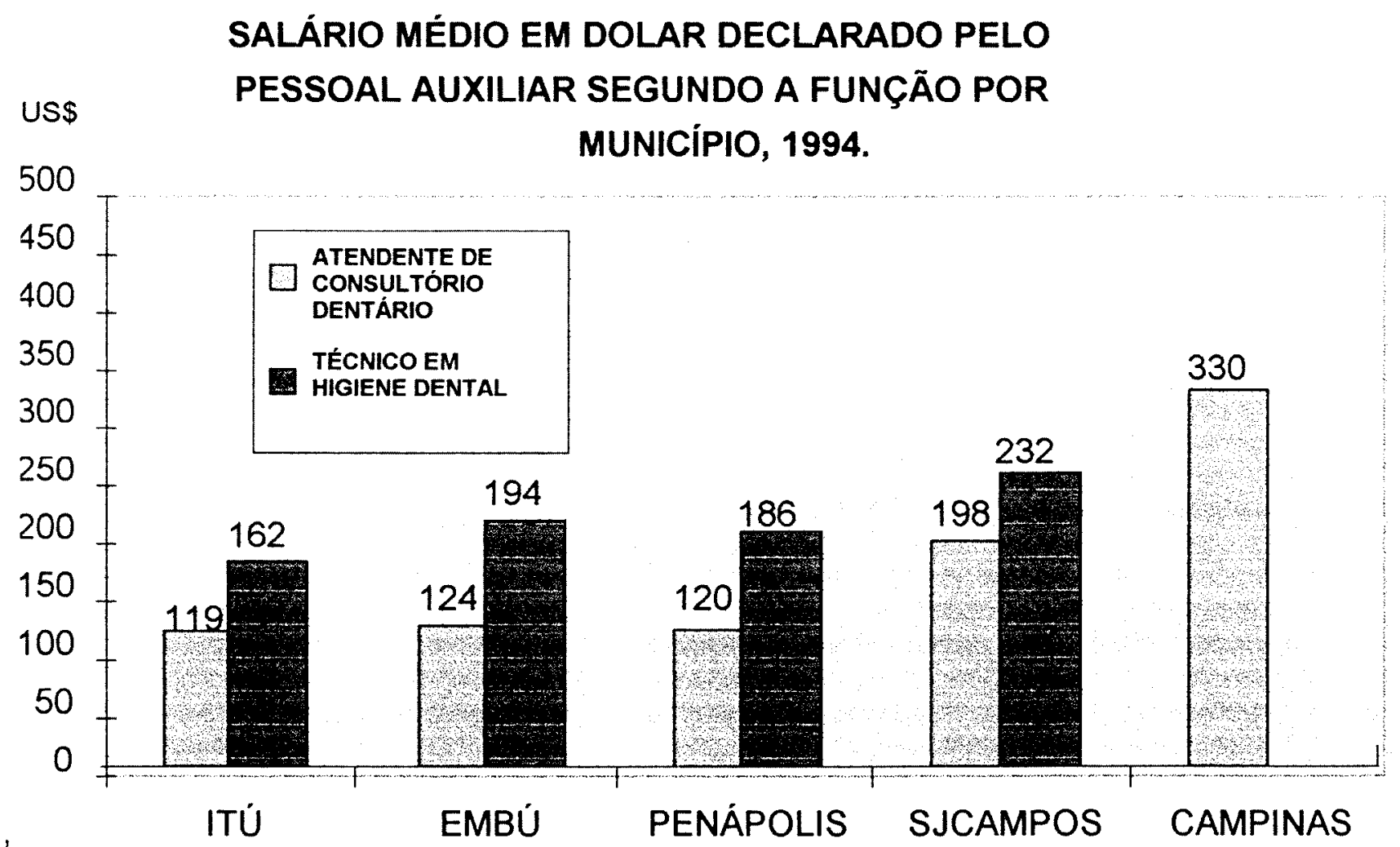


Nas tabelas $8,9,10,11$ e 12 são apresentados os percentuais de horastrabalho do PAO, segundo a função: ACD ou THD, segundo o local de trabalho: unidades básicas de saúde ou escolas/espaços sociais, por municipio e SILOS.

Considerando um percentual na faixa de 40 a $60 \%$ como critério de um certo equilíbrio observa-se, na tabela 8 , que havia um balanceamento na distribuição de horastrabalho do PAO por unidades básicas de saúde e escolas/espaços sociais em Itú, Embú, Penápolis e Campinas. Em S. José dos Campos predominavam horas-trabalho em escolas/espaços sociais.

\section{TABELA 8}

Número de horas-trabalho por mês declarados pelo pessoal auxiliar segundo o local e o municipio, 1994.

\begin{tabular}{|c|c|c|c|c|c|c|}
\hline \multirow[b]{3}{*}{ MUNICÍPIO } & \multicolumn{4}{|c|}{ N HORAS-TRABALHO POR MÊS } & & \\
\hline & \multicolumn{2}{|c|}{ em UBS 1} & \multicolumn{2}{|c|}{ em $\mathrm{ESC}^{2}$} & \multicolumn{2}{|c|}{ TOTAL } \\
\hline & $f$ & $\%$ & $f$ & $\%$ & $f$ & $\%$ \\
\hline Itú & 3352 & 61,8 & 2068 & 38,2 & 5420 & 100,0 \\
\hline Embú & 1440 & 40,9 & 2080 & 59,1 & 3520 & 100,0 \\
\hline Penápolis & 1520 & 55,9 & 1200 & 44,1 & 2720 & 100,0 \\
\hline SJCampos & 3040 & 16,5 & 15408 & 83,5 & 18448 & 100,0 \\
\hline Campinas & 4820 & 60,0 & 3220 & 40,0 & 8040 & 100,0 \\
\hline
\end{tabular}

1: unidades básicas de saúde.

2: escolas, creches ou outros espaços sociais.

Este resultado não foi observado em todos os SILOS dos municipios de S. José dos Campos e Campinas. Conforme as tabelas 9 e 10, o SILOS centro de S. José dos Campos apresentava um certo balanceamento na distribuição de horas-trabalho do PAO por unidades básicas de saúde e escolas/espaços sociais, e o SILOS leste de Campinas possuia maior percentual de horas-trabalho do PAO em unidades básicas de saúde. 
TABELA 9

Número de horas-trabalho por mês declarados pelo pessoal auxiliar do municipio de $\mathrm{S}$. José dos Campos segundo o local e o sistema local de saúde, 1994.

\begin{tabular}{|c|c|c|c|c|c|c|}
\hline \multirow[b]{3}{*}{ SILOS } & \multicolumn{4}{|c|}{ N' DE HORAS-TRABALHO POR MÊS } & & \\
\hline & \multicolumn{2}{|c|}{ em UBS 1} & \multicolumn{2}{|c|}{ em ESC2 } & \multicolumn{2}{|c|}{ TOTAL } \\
\hline & $f$ & $\%$ & $f$ & $\%$ & $f$ & $\%$ \\
\hline Centro & 1680 & 37,8 & 2768 & 62,2 & 4448 & 100,0 \\
\hline Norte & 400 & 14,7 & 2320 & 85,3 & 2720 & 100,0 \\
\hline Sul & 560 & 8,0 & 6400 & 92,0 & 6960 & 100,0 \\
\hline Leste & 400 & 9,3 & 3920 & 90,7 & 4320 & 100,0 \\
\hline TOTAL & 3040 & 16,5 & 15408 & 83,5 & 18448 & 100,0 \\
\hline
\end{tabular}

1: unidades básicas de saúde.

2: escolas, creches ou outros espaços sociais.

TABELA 10

Número de horas-trabalho por mês declarados pelo pessoal auxiliar do município de Campinas segundo o local e o sistema local de saúde, 1994.

\begin{tabular}{|c|c|c|c|c|c|c|}
\hline \multirow[b]{3}{*}{ SILOS } & \multicolumn{4}{|c|}{ NN DE HORAS-TRABALHO POR MÊS } & & \\
\hline & \multicolumn{2}{|c|}{ em UBS 1} & \multicolumn{2}{|c|}{ em ESC 2} & \multicolumn{2}{|c|}{ TOTAL } \\
\hline & $f$ & $\%$ & $f$ & $\%$ & $f$ & $\%$ \\
\hline Oeste & 1960 & 52,7 & 1760 & 47,3 & 3720 & 100,0 \\
\hline Leste & 1760 & 73,3 & 640 & 26,7 & 2400 & 100,0 \\
\hline Norte & 1100 & 57,3 & 820 & 42,7 & 1920 & 100,0 \\
\hline TOTAL & 4820 & 60,0 & 3220 & 40,0 & 8040 & 100,0 \\
\hline
\end{tabular}

1: unidades básicas de saúde.

2: escolas, creches ou outros espaços sociais.

Ao desagregar os dados por tipo de PAO, observou-se certa compensação na distribuição de horas-trabalho de ACDs (tabela 11) em todos os municipios e de THDs (tabela 12) somente no município de Embú. No município de S.José dos Campos 
predominava horas-trabalho de THDs em escolas/espaços sociais e nos municípios de ltú e Penápolis prevalecia horas-trabalho em unidades básicas de saúde.

\section{TABELA 11}

Número de horas-trabalho por mês declarados pelo pessoal que exerce a função de ACD segundo o local e o município, 1994.

\begin{tabular}{|c|c|c|c|c|c|c|}
\hline \multirow[b]{3}{*}{ MUNICÍPIO } & \multicolumn{4}{|c|}{$N^{\circ}$ DE HORAS-TRABALHO POR MÊS } & & \\
\hline & \multicolumn{2}{|c|}{ em UBS 1} & \multicolumn{2}{|c|}{ em ESC2 } & \multicolumn{2}{|c|}{ TOTAL } \\
\hline & $f$ & $\%$ & $f$ & $\%$ & $f$ & $\%$ \\
\hline Itú & 2552 & 59,3 & 1748 & 40,7 & 4300 & 100,0 \\
\hline Embú & 800 & 41,6 & 1120 & 58,4 & 1920 & 100,0 \\
\hline Penápolis & 800 & 45,5 & 960 & 54,5 & 1760 & 100,0 \\
\hline SJCampos & 2960 & 39,8 & 4480 & 60,2 & 7440 & 100,0 \\
\hline Campinas & 4820 & 60,0 & 3220 & 40,0 & 8040 & 100,0 \\
\hline
\end{tabular}

1: unidades básicas de saúde.

2: escolas, creches ou outros espaços sociais.

TABELA 12

Número de horas-trabalho por mês declarados pelo pessoal que exerce a função de THD segundo o local e o municipio, 1994.

\begin{tabular}{|c|c|c|c|c|c|c|}
\hline \multirow[b]{3}{*}{ MUNICIPIO } & \multicolumn{4}{|c|}{$N^{\circ}$ DE HORAS-TRABALHO POR MÊS } & & \\
\hline & \multicolumn{2}{|c|}{ em UBS ${ }^{1}$} & \multicolumn{2}{|c|}{ em ESC2 } & \multicolumn{2}{|c|}{ TOTAL } \\
\hline & $f$ & $\%$ & $f$ & $\%$ & $f$ & $\%$ \\
\hline Itú & 800 & 71,4 & 320 & 28,6 & 1120 & 100,0 \\
\hline Embú & 640 & 40,0 & 960 & 60,0 & 1600 & 100,0 \\
\hline Penápolis & 720 & 75,0 & 240 & 25,0 & 960 & 100,0 \\
\hline SJCampos & 80 & 0,7 & 10928 & 99,3 & 11008 & 100,0 \\
\hline Campinas & - & - & - & - & - & - \\
\hline
\end{tabular}

1: unidades básicas de saúde.

2: escolas, creches ou outros espaços sociais. 
Cabe ainda destacar, que observou-se diferenças internas na distribuição de horas-trabalho dos ACDs nos SILOS dos municipios de S. José dos Campos e de Campinas. Enquanto nos SILOS centro de S. José dos Campos e leste de Campinas predominavam horas-trabalho de ACDs em unidades básicas de saúde, nos SILOS norte e sul de S. José dos Campos, o predomínio recaía em escolas/espaços sociais.

\subsection{CARACTERISTICAS DA PARTICIPAÇÃO EM AÇŌES COLETIVAS}

Uma atividade coletiva importante em programas de saúde bucal bem orientados, é a realização de levantamentos epidemiológicos de cárie dentária. Nesse aspecto, cabe destacar os dados apresentados na tabela 13, em que o percentual de PAO que já participou deste tipo de atividade esteve sempre acima de $50 \%$, em todos os SILOS.

\section{TABELA 13}

Número e percentual do pessoal que auxilia ou já auxiliou o dentista nas atividades de exame ou levantamento de cárie dentária em grupos populacionais segundo a função que exerce e o SILOS, 1994.

\begin{tabular}{crrrrc}
\hline & \multicolumn{5}{c}{ FUNÇÃO } \\
\cline { 2 - 5 } SILOS & ACD & $\%$ & N & $\%$ \\
\hline Itú & 24 & 77,4 & 6 & 85,7 \\
Embú & 11 & 84,6 & 10 & 100,0 \\
Penápolis & 7 & 63,6 & 5 & 83,3 \\
SJCampos/Centro & 10 & 62,5 & 12 & 85,7 \\
SJCampos/Norte & 7 & 70,0 & 5 & 62,5 \\
SJCampos/Sul & 8 & 57,2 & 15 & 57,7 \\
SJCampos/Leste & 6 & 100,0 & 20 & 95,2 \\
Campinas/Oeste & 15 & 60,0 & - & - \\
Campinas/Leste & 9 & 60,0 & - & - \\
Campinas/Norte & 7 & 58,3 & - & - \\
\hline
\end{tabular}


Além desta atividade, pesquisou-se a participação do PAO em ações coletivas de bochechos fluorados (BF), evidenciação de placa bacteriana seguida de escovação supervisionada (ES), aplicação de flúor com escova ou moldeira (AF) e atividades educativas (AE), como por exemplo palestras, reuniões etc.

Os gráficos 2, 3, 4 e 5 apresentam os resultados podendo-se verificar o percentual de PAO que declarou realizar estas atividades, tanto em unidades básicas de saúde como em escolas e outros espaços sociais em cada SILOS. De modo geral, verificase na maioria dos SILOS que a participação do PAO em atividades coletivas é maior quando se trata da realização dessas atividades em escolas e espaços sociais, confirmando experiências e diretrizes oficiais de odontologia em saúde coletiva.

Percebe-se que o fator SILOS exerce influência na distribuição destas atividades coletivas. Em Embú, por exemplo, a maioria do PAO estava fazendo estas atividades em ambos os locais de trabalho, à exceção dos bochechos fluorados oferecidos em escolas/espaços sociais. Nos SILOS de S. José dos Campos, todas as atividades elencadas foram realizadas pela maioria do PAO em escolas e outros espaços sociais. Em Penápolis, a maioria do PAO estava fazendo ES e BF em escolas/espaços sociais. Em Campinas, a participação foi mais observada nas atividades coletivas de ES e AE nos dois locais de trabalho. Em Itú, verificou-se participação significativa somente na atividade de ES em ambos os locais de trabalho. 


\section{GRÁFICO 2}

PERCENTUAL DE AUXILIARES (ACD+THD) QUE FAZEM BOCHECHOS FLUORADOS SEGUNDO O LOCAL DE TRABALHO POR SILOS, 1994.

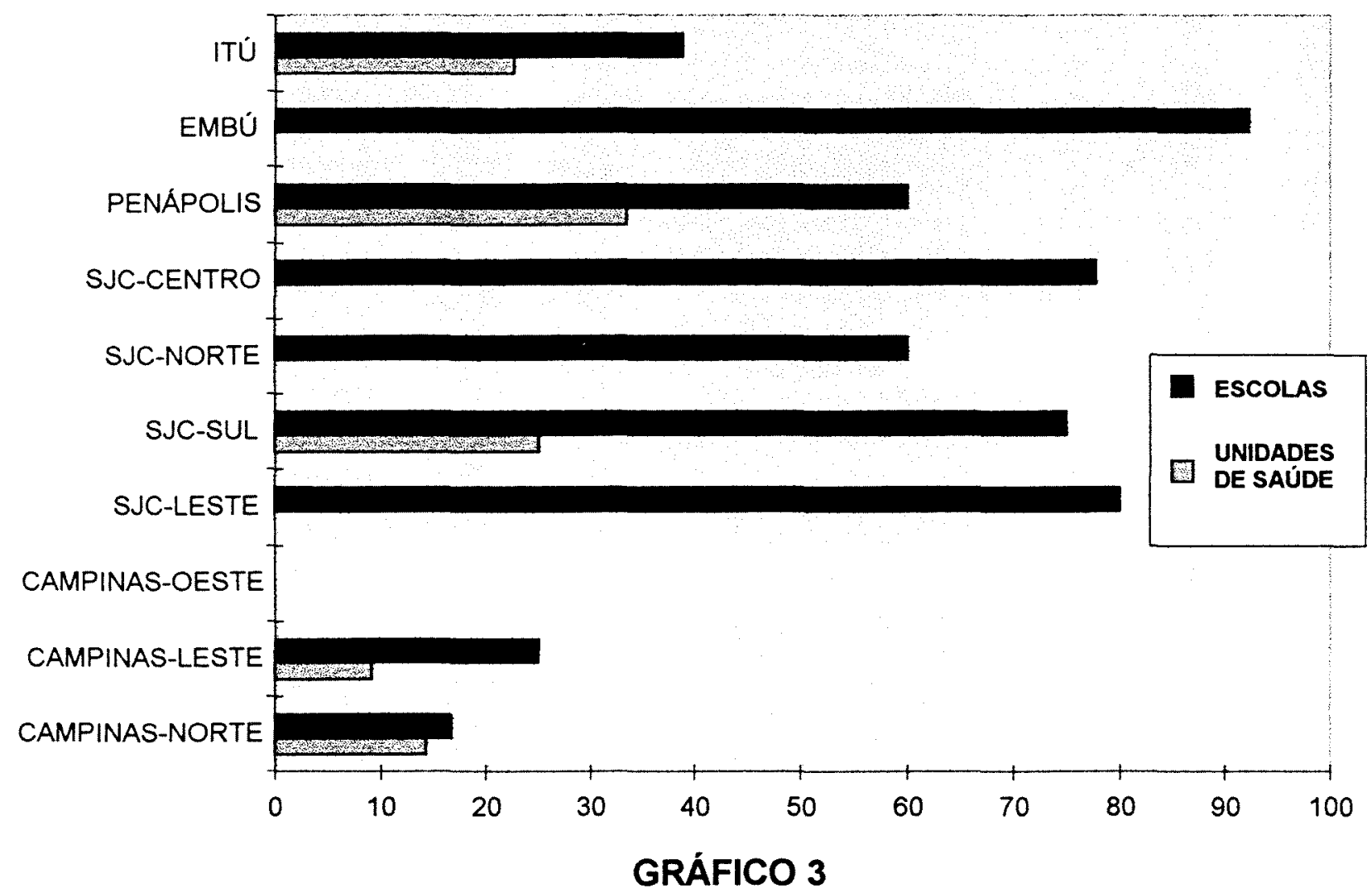

PERCENTUAL DE AUXILIARES (ACD+THD) QUE FAZEM EVIDENCIAÇÃO DE PLACA BACTERIANA SEGUIDA DE ESCOVAÇÃO SUPERVISIONADA SEGUNDO O LOCAL DE TRABALHO POR SILOS, 1994.

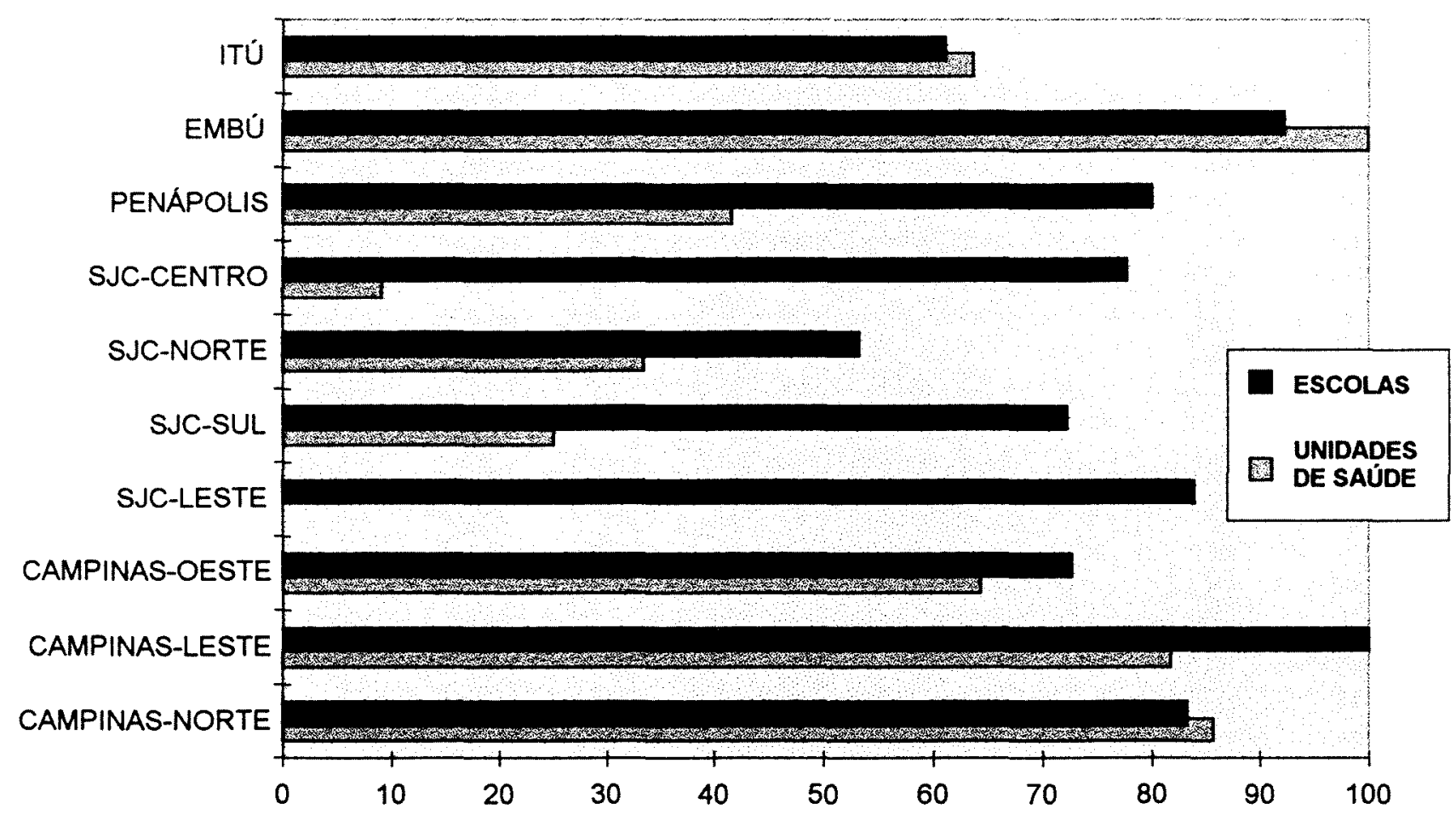




\section{GRÁFICO 4}

PERCENTUAL DE AUXILIARES (ACD+THD) QUE FAZEM APLICAÇÃO DE FLÚOR COM ESCOVA OU MOLDEIRA SEGUNDO O LOCAL DE TRABALHO POR SILOS, 1994.

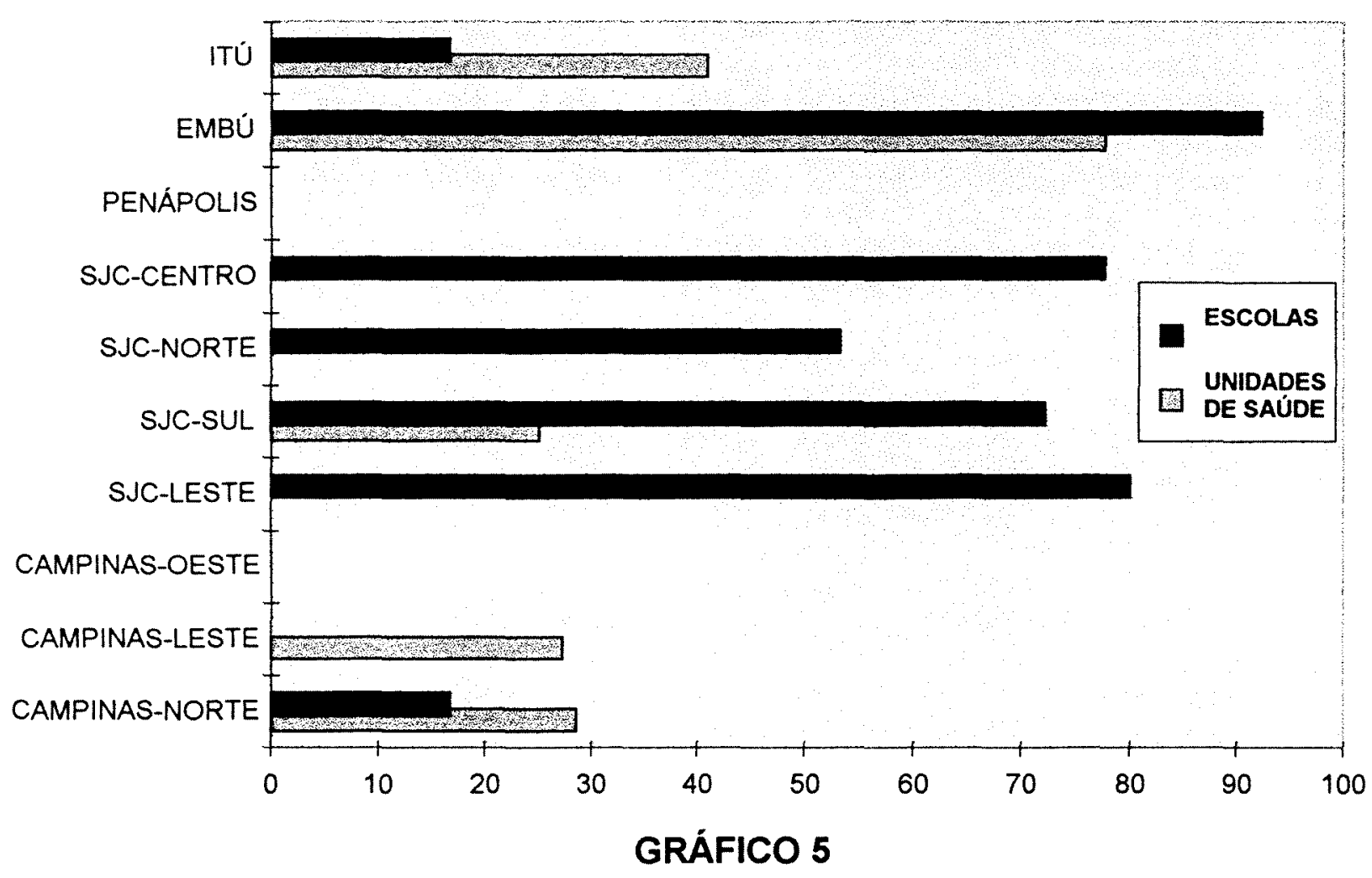

PERCENTUAL DE AUXILIARES (ACD+THD) QUE FAZEM ATIVIDADES EDUCATIVAS SEGUNDO O LOCAL DE TRABALHO POR SILOS, 1994.

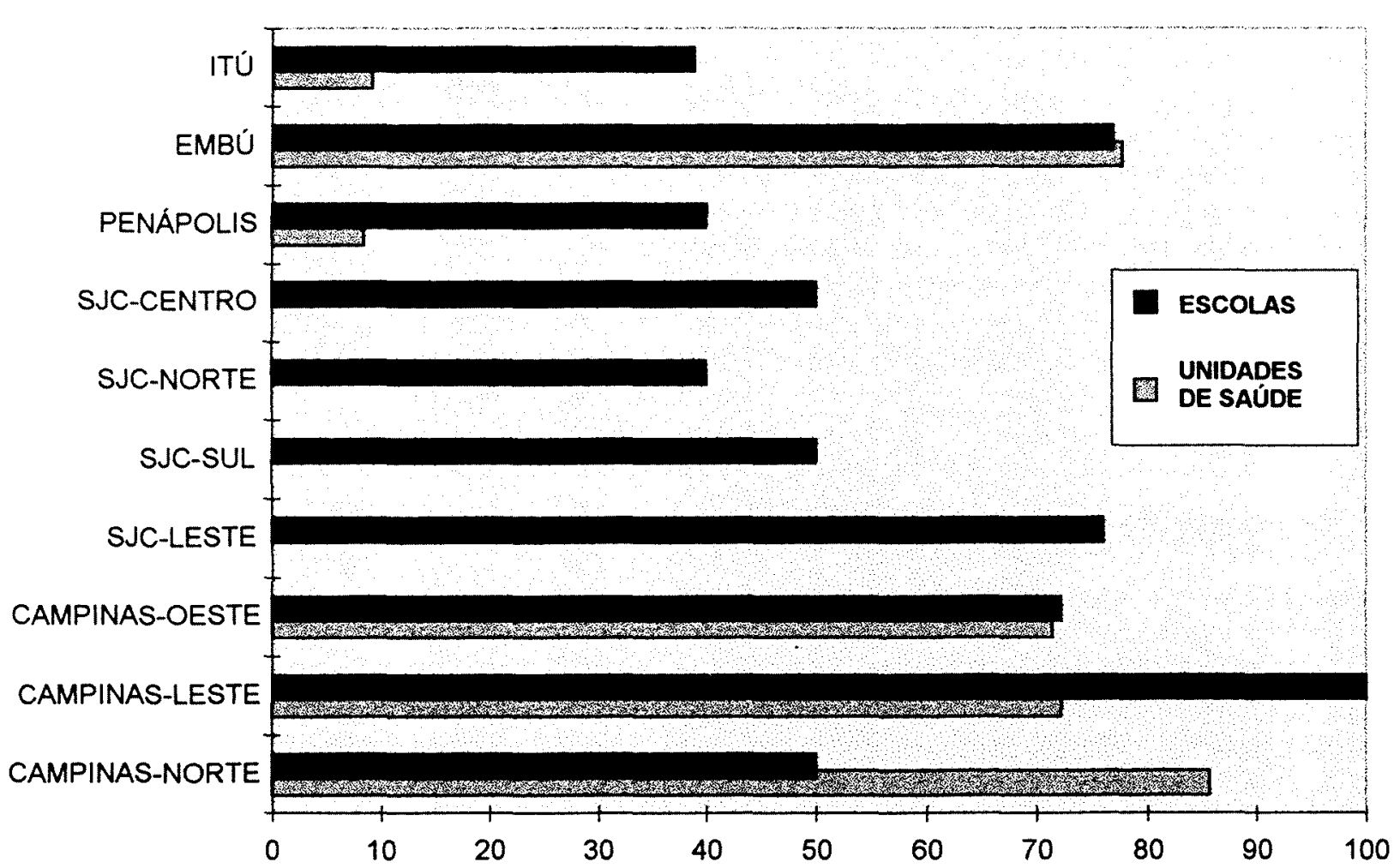


Os gráficos 6, 7, 8 e 9 apresentam aspectos quantitativos relativos a essa participação, estimados à partir das declaraçð̃es do PAO e de parâmetros de rendimento médio aplicados de modo idêntico a todos os dados. Esse rendimento foi calculado através do número de pessoas beneficiadas, da média de pessoas beneficiadas por auxiliar; do gasto estimado de tempo dispendido por auxiliar, do número de auxiliares e do total estimado de tempo dispendido por mês, cujas tabelas encontram-se no Anexo II.

O gráfico 6 refere-se à diferentes ações coletivas desenvolvidas em escolas e outros espaços sociais.

\section{GRÁFICO 6}

\section{NÚMERO MÉDIO DE PESSOAS BENEFICIADAS MENSALMENTE EM ESCOLAS E OUTROS ESPAÇOS SOCIAIS POR AUXILIAR SEGUNDO O TIPO DE AÇÃO COLETIVA E O SILOS. 1994.}

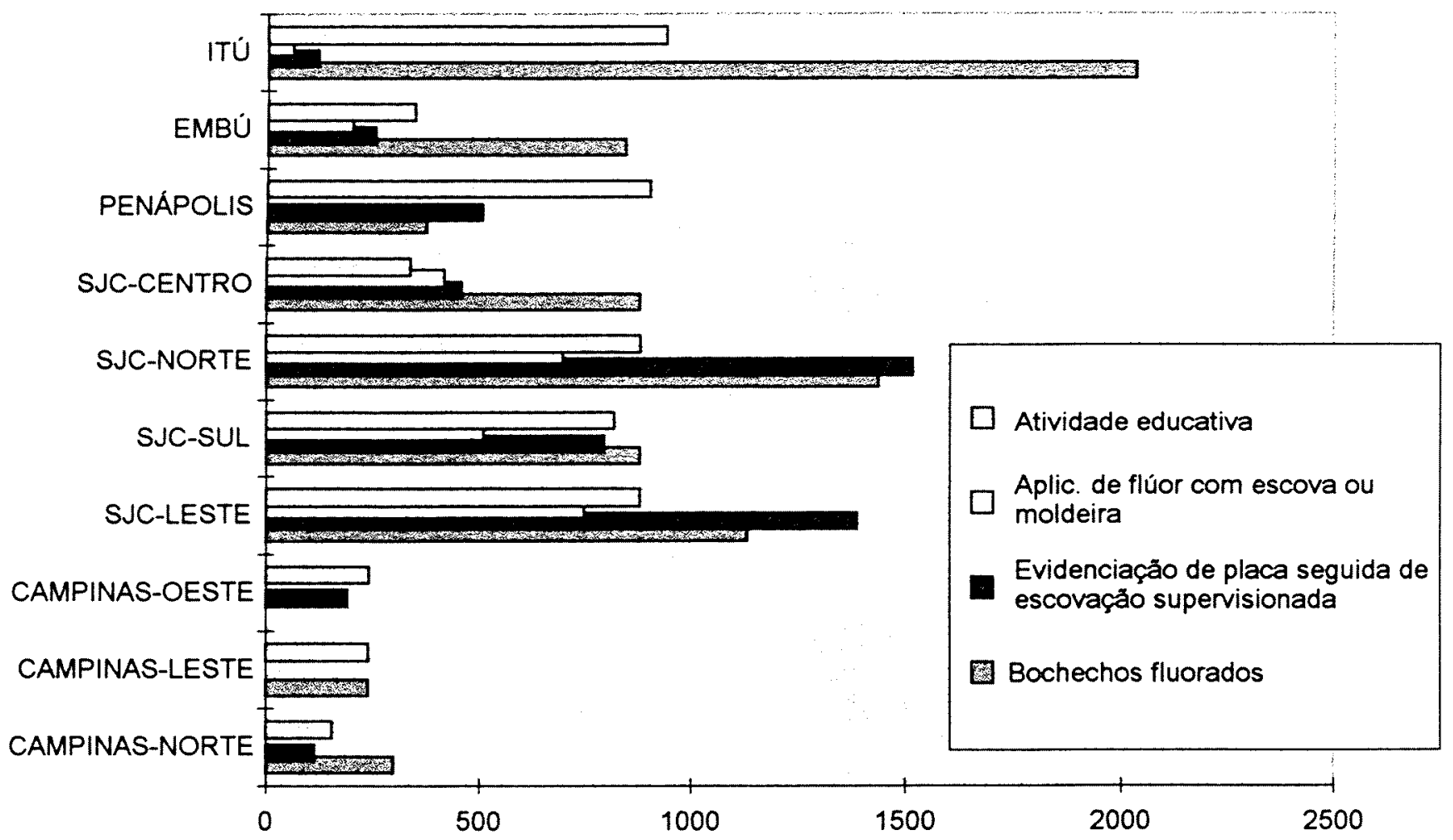

Pode-se verificar que na maioria dos SILOS é bastante expressivo o benefício proporcionado pela participação do PAO no provimento de ações coletivas em escolas/espaços sociais.

Com base nesses dados foi possível estimar o número médio de horas por semana do PAO de cada SILOS dispendido em cada ação coletiva. O gráfico 7 ilustra esses resultados. Conforme descrito no capítulo 4, desprezou-se o tempo dispendido nas 
atividades educativas por admitir-se este tempo já incluido nas demais atividades coletivas consideradas.

\section{GRÁFICO 7}

MÉDIA DE HORAS POR SEMANA DE AUXILIARES (ACD+THD) DISPENDIDAS COM AÇÕES COLETIVAS EM ESCOLAS E OUTROS ESPAÇOS SOCIAIS SEGUNDO O SILOS, 1994.

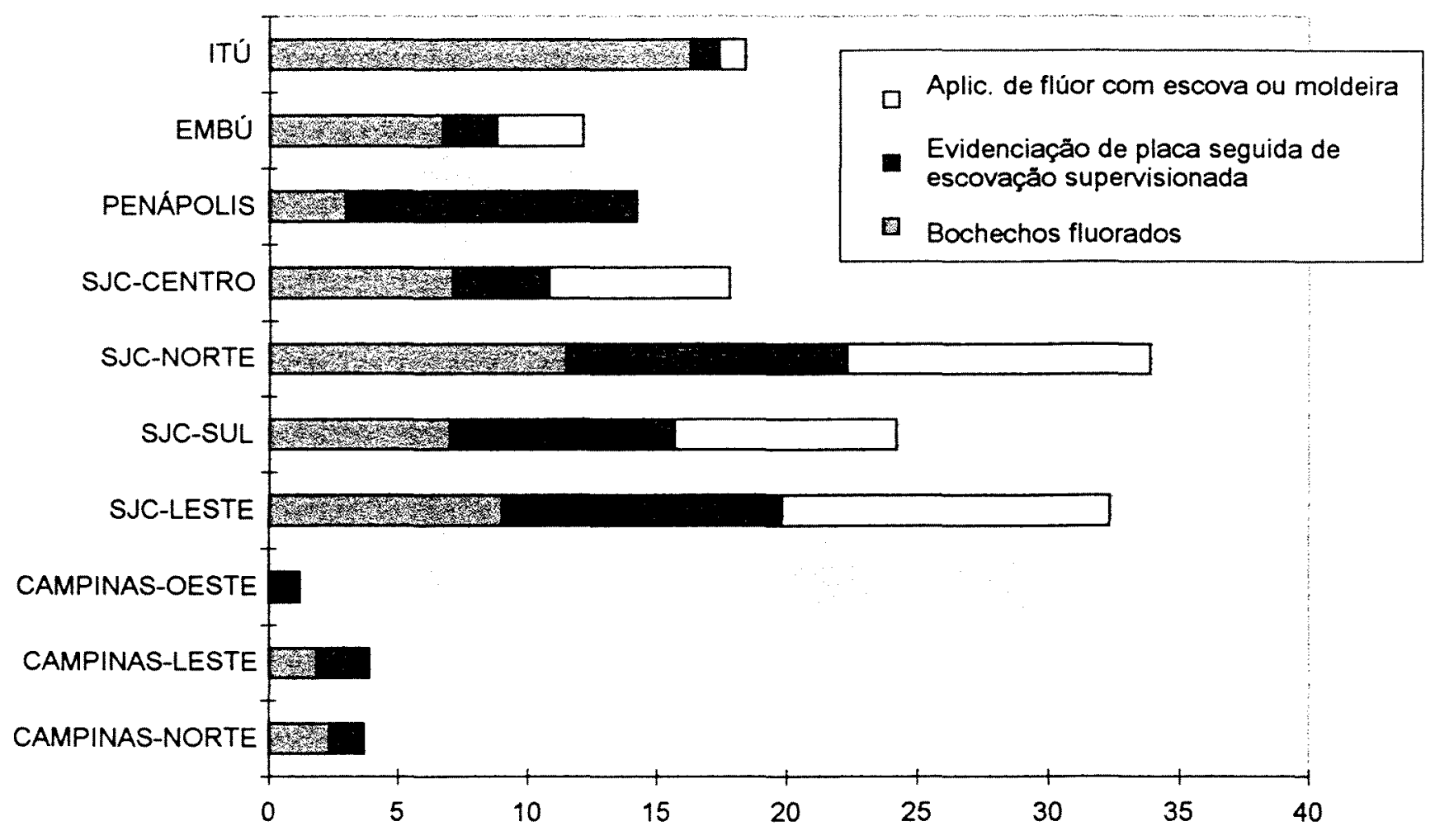

Em relação à escolas e outros espaços sociais, pode-se observar que, nos SILOS norte, sul e leste de $S$. José dos Campos é bem expressivo o gasto de tempo da jornada de trabalho do PAO com ações coletivas. Uma posição mais intermediária é ocupada pelo PAO de Itú, Embú, Penápolis e SILOS centro de São José dos Campos com aproximadamente metade da jornada sendo dispendida com essas ações.

O gráfico 8 refere-se à ações coletivas desenvolvidas em unidades básicas de saúde. 


\section{GRÁFICO 8}

NÚMERO MÉdIO DE PESSOAS BENEFICIADAS MENSALMENTE EM UNIDADES BÁSICAS DE SAÚDE POR AUXILIAR SEGUNDO O TIPO DE AÇÃO COLETIVA E O SILOS, 1994.

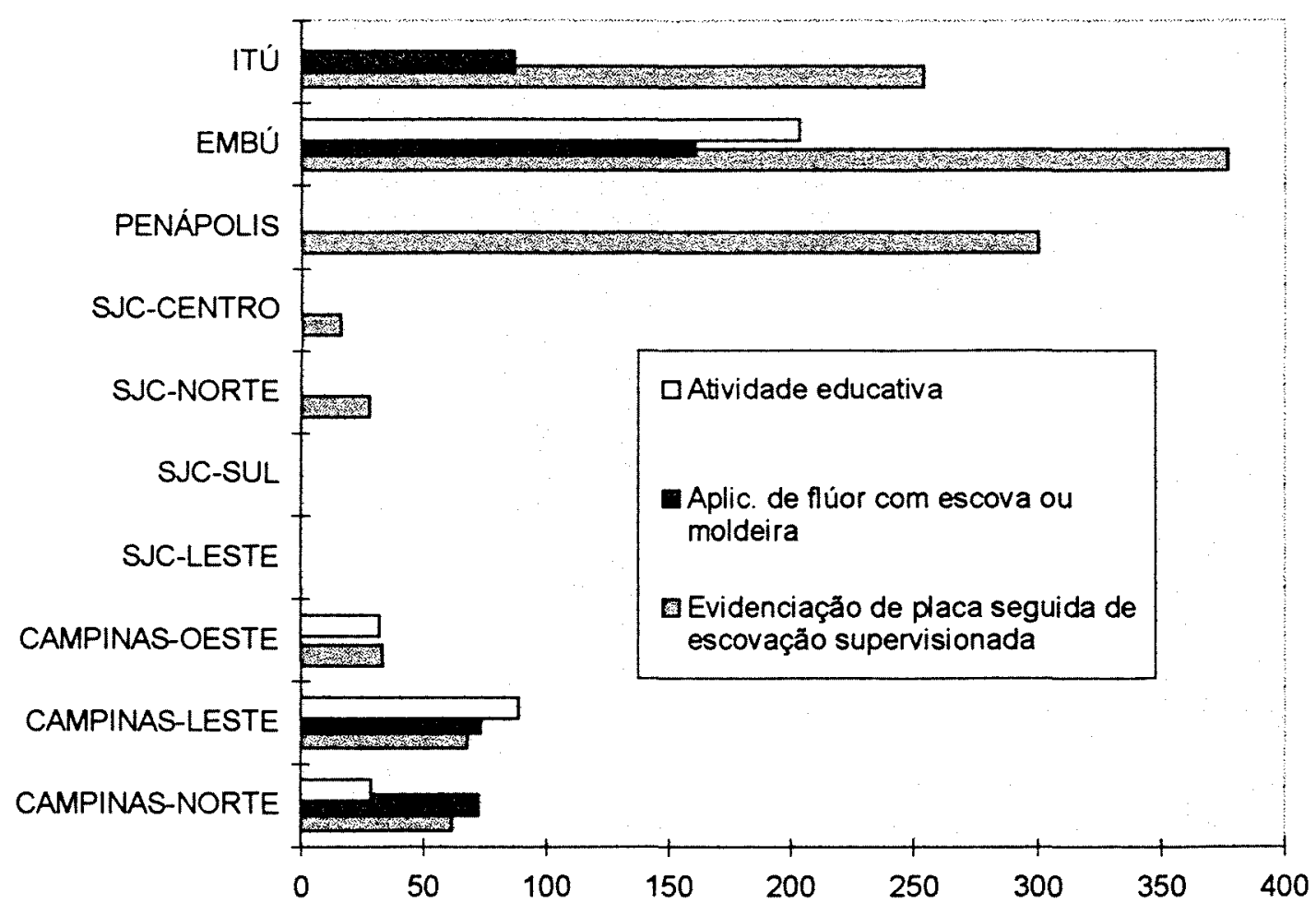

Observa-se que ao contrário dos demais SILOS e diferentemente do verificado em escolas/espaços sociais, somente Itú, Embú e Penápolis apresentam expressiva proporção de pessoas beneficiadas em unidades básicas de saúde por alguma das atividades coletivas pesquisadas.

Com esses dados calculou-se o número médio de horas por semana do PAO de cada SILOS no provimento de cada ação coletiva em unidades básicas de saúde, excluindo-se as atividades educativas conforme exposto anteriormente. 0 gráfico 9 ilustra esses resultados. 


\section{GRÁFICO 9}

MÉDIA DE HORAS POR SEMANA DE AUXILIARES (ACD+THD) DISPENDIDA COM AÇÕES COLETIVAS EM UNIDADES BÁSICAS DE SAÚDE SEGUNDO O SILOS, 1994.

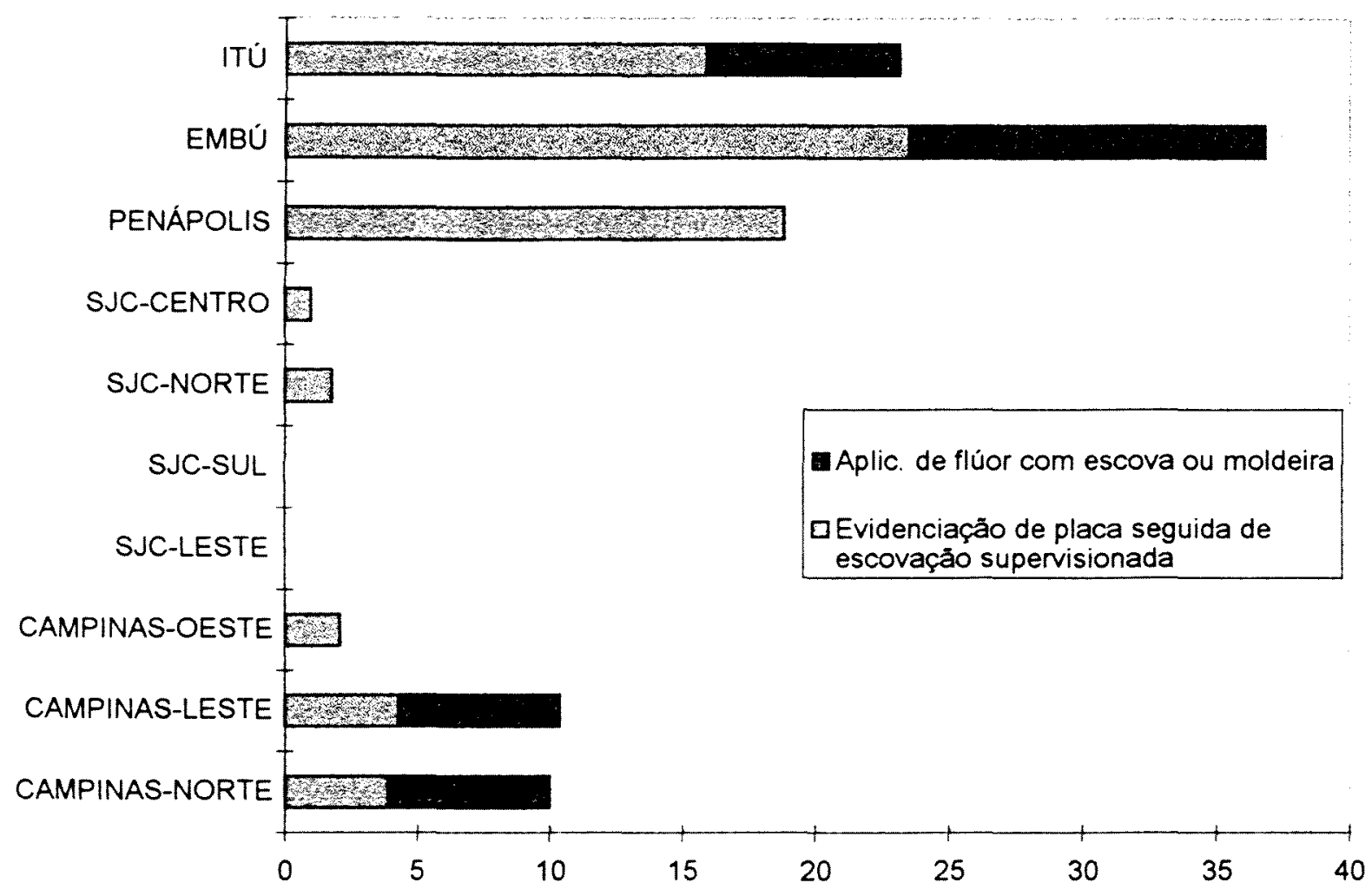

Em unidades básicas de saúde destaca-se o SILOS de Embú em que é bem expressivo o gasto de tempo da jornada de trabalho do PAO com ações coletivas. Uma posição mais intermediária é ocupada pelo PAO do SILOS de Itú e Penápolis com aproximadamente metade da jornada sendo dispendida com essas ações em unidades básicas de saúde.

Nas tabelas 14 e 15 são apresentados os resultados dos cálculos efetuados para se estimar o percentual de tempo da jornada de trabalho dispendido em açðes coletivas da totalidade do PAO empregado, portanto, incluindo também os que declararam não realizar essas açōes. Os resultados referem-se, respectivamente, à unidades básicas de saúde e à escolas/espaços sociais e permitem estabelecer comparações entre os diferentes SILOS e com o restante do tempo, considerado na pesquisa, gasto com ações de assistência odontológica individual. O gráfico 10 apresenta de forma sintética tais resultados. 


\section{TABELA 14}

Distribuição estimada do tempo da jornada mensal de trabalho do pessoal auxiliar dispendido em atividades coletivas de evidenciação de placa seguida de escovação supervisionada e aplicação de flúor com escova ou moldeira e atividades na assistência individual em unidades básicas de saúde segundo o sistema local de saúde, 1994.

\begin{tabular}{|c|c|c|c|c|c|c|c|c|}
\hline \multirow[t]{2}{*}{ SILOS } & \multirow{2}{*}{$\begin{array}{c}\text { hs/trabalho } \\
\text { escovação } \\
\text { supervisionada } \\
\text { f }\end{array}$} & \multirow{2}{*}{$\begin{array}{l}\text { hs/trabalho } \\
\text { aplicação de } \\
\text { flúor } \\
f\end{array}$} & \multicolumn{2}{|c|}{$\begin{array}{c}\text { hs/trabalho } \\
\text { atividade } \\
\text { coletiva }\end{array}$} & \multicolumn{2}{|c|}{$\begin{array}{l}\text { hs/trabalho } \\
\text { atividade } \\
\text { individual }\end{array}$} & \multicolumn{2}{|c|}{$\begin{array}{l}\text { total mensal } \\
\text { de } \\
\text { hs/trabalho }\end{array}$} \\
\hline & & & $f$ & $\%$ & $f$ & $\%$ & $f$ & $\%$ \\
\hline Itú & 761,1 & 86,7 & 847,8 & 25,3 & 2504,2 & 74,7 & 3352 & 100,0 \\
\hline Embú & 752,8 & 319,9 & 1072,7 & 74,5 & 367,3 & 25,5 & 1440 & 100,0 \\
\hline Penápolis & 150,0 & - & 150,0 & 10,0 & 1370,0 & 90,0 & 1520 & 100,0 \\
\hline SJC-Centro & 4,0 & - & 4,0 & 0,0 & 1676,0 & 100,0 & 1680 & 100,0 \\
\hline SJC-Norte & 7,0 & - & 7,0 & 1,8 & 393,0 & 98,2 & 400 & 100,0 \\
\hline SJC-Sul & - & - & - & - & 560,0 & 100,0 & 560 & 100,0 \\
\hline SJC-Leste & - & - & - & - & 400,0 & 100,0 & 400 & 100,0 \\
\hline Camp-Oeste & 67,0 & - & 67,0 & 3,4 & 1893,0 & 96,6 & 1960 & 100,0 \\
\hline Camp-Leste & 153,9 & 73,2 & 227,1 & 12,9 & 1532,9 & 87,1 & 1760 & 100,0 \\
\hline Camp-Norte & 92,4 & 48,4 & 140,8 & 12,8 & 959,2 & 87,2 & 1100 & 100,0 \\
\hline
\end{tabular}




\section{TABELA 15}

Distribuição estimada do tempo da jornada mensal de trabalho do pessoal auxiliar dispendido em atividades coletivas de evidenciação de placa seguida de escovação supervisionada, bochechos fluorados e aplicação de flúor com escova ou moldeira, e atividades na assistência individual em escolas e outros espaços sociais segundo o sistema local de saúde, 1994.

\begin{tabular}{lccccccccc}
\hline SILOS & $\begin{array}{c}\text { hs-trab. } \\
\text { bochecho }\end{array}$ & $\begin{array}{c}\text { hs-trab. } \\
\text { escov. } \\
\text { supervis. }\end{array}$ & $\begin{array}{c}\text { hs-trab. } \\
\text { aplicação } \\
\text { de flúor }\end{array}$ & & $\begin{array}{c}\text { hs-trabalho } \\
\text { atividade } \\
\text { coletiva }\end{array}$ & $\begin{array}{c}\text { hs-trabalho } \\
\text { atividade } \\
\text { individual }\end{array}$ & $\begin{array}{c}\text { total mensal } \\
\text { de horas- } \\
\text { trabalho }\end{array}$ \\
\cline { 8 - 11 } & $f$ & $f$ & $f$ & $f$ & $\%$ & $f$ & $\%$ & $f$ & $\%$ \\
Itú & 391,2 & 37,8 & 12,0 & 441,0 & $\mathbf{2 1 , 3}$ & 1627,0 & $\mathbf{7 8 , 7}$ & 2068 & 100,0 \\
Embú & 322,8 & 100,8 & 159,6 & 583,2 & $\mathbf{2 8 , 0}$ & 1496,8 & $\mathbf{7 2 , 0}$ & 2080 & 100,0 \\
Penápolis & 96,0 & 356,8 & - & 452,8 & $\mathbf{3 7 , 7}$ & 747,2 & $\mathbf{6 2 , 3}$ & 1200 & 100,0 \\
SJC-Centro & 397,6 & 205,8 & 389,2 & 992,6 & $\mathbf{3 5 , 8}$ & 1775,4 & $\mathbf{6 4 , 2}$ & 2768 & 100,0 \\
SJC-Norte & 414,0 & 344,0 & 371,2 & 1129,2 & $\mathbf{4 8 , 7}$ & 1190,8 & $\mathbf{5 1 , 3}$ & 2320 & 100,0 \\
SJC-Sul & 759,6 & 899,6 & 884,0 & 2543,2 & $\mathbf{3 9 , 7}$ & 3856,8 & $\mathbf{6 0 , 3}$ & 6400 & 100,0 \\
SJC-Leste & 652,8 & 905,1 & 1045,8 & 2603,7 & $\mathbf{6 6 , 4}$ & 1316,3 & $\mathbf{3 3 , 6}$ & 3920 & 100,0 \\
Camp-Oeste & - & 43,2 & - & 43,2 & $\mathbf{2 , 5}$ & 1716,8 & $\mathbf{9 7 , 5}$ & 1760 & 100,0 \\
Camp-Leste & 7,6 & 32,0 & - & 39,6 & $\mathbf{6 , 2}$ & 600,4 & $\mathbf{9 3 , 8}$ & 640 & 100,0 \\
Camp-Norte & 9,6 & 20,0 & - & 29,6 & $\mathbf{3 , 6}$ & 790,4 & $\mathbf{9 6 , 4}$ & 820 & 100,0 \\
\hline
\end{tabular}

Destaca-se o maior tempo dispendido em açðes coletivas verificado no SILOS de Embú e nas regiðes norte e leste de São José dos Campos, respectivamente em unidades básicas de saúde e em escolas/espaços sociais, evidenciando que, quando comparado com os demais, o PAO destes três SILOS apresenta um expressivo tempo dispendido em açőes coletivas, bem superior aos demais sistemas. A posição mais intermediária é ocupada pelo PAO dos SILOS de Penápolis, Sul e Centro de São José dos Campos com ações coletivas em escolas/espaços sociais. Em seguida observa-se a 
participação do PAO dos SILOS de Embú em escolas/espaços sociais e de Itú em ambos os locais de trabalho.

\section{GRÁFICO 10}

TEMPO DE JORNADA DE TRABALHO DE AUXILIARES (ACD+THD) DISPENDIDO EM AÇÕES COLETIVAS SEGUNDO O LOCAL DE TRABALHO POR SILOS, 1994. PERCENTUAL.

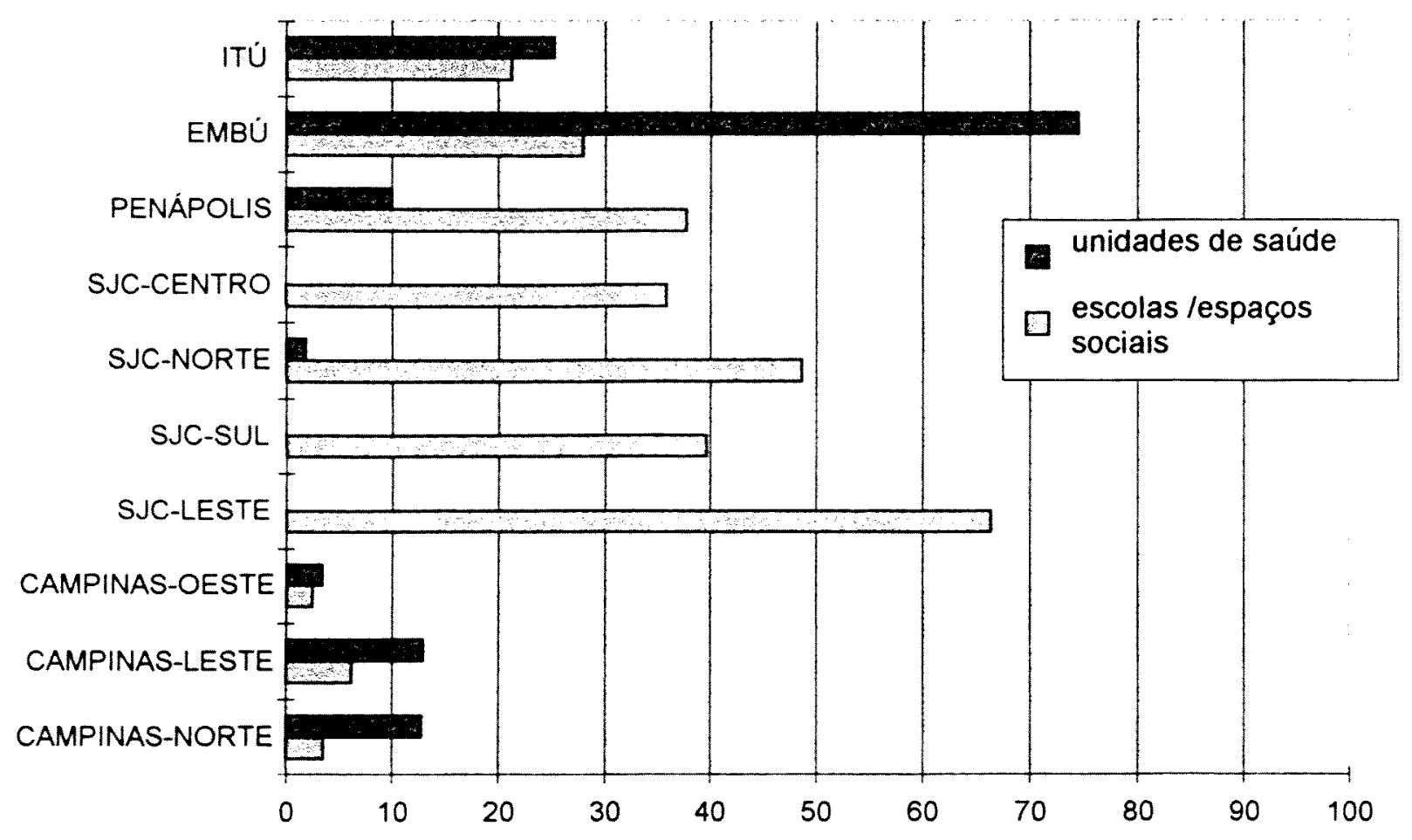




\subsection{CARACTERISTICAS DA PARTICIPAÇÃO NA ASSISTÊNCIA INDIVIDUAL}

Excetuando-se as atividades de orientação de pacientes, as principais tarefas na clínica odontológica típicas de ACDs, estavam sendo realizadas pela maioria deles. Observa-se, ainda, que mais da metade dos THDs dos quatro municípios exerciam também estas tarefas.

A tabela 16 mostra que, das tarefas pesquisadas, a instrumentação à quatromãos era realizada por cerca de metade dos ACDs e $10 \%$ dos THDs.

\section{TABELA 16}

Número e percentual do pessoal auxiliar segundo a função e a realização de tarefas na assistência individual, 1994

\begin{tabular}{ccccc}
\hline & \multicolumn{2}{c}{ ACD } & \multicolumn{2}{c}{ THD } \\
\cline { 2 - 5 } TAREFAS & $f$ & $\% 1$ & $f$ & $\%^{2}$ \\
\hline Prepara a sala de odonto & 151 & 98,7 & 59 & 64,1 \\
Limpa e desinfeta materiais & 151 & 98,7 & 65 & 70,7 \\
Esteriliza instrumentos & 148 & 96,7 & 57 & 26,0 \\
Prepara cimentos e outros materiais & 147 & 96,1 & 49 & 53,3 \\
Trabalha à quatro-mãos & 85 & 55,6 & 10 & 10,9 \\
\hline
\end{tabular}

1: percentual calculado em relação à 153 ACDs

2: percentual calculado em relação à 92 THDs 
Ao desagregar os dados por SILOS (tabela 17), percebe-se que em ltú e Campinas, a maioria do PAO estava trabalhando à quatro-mãos. Em Embú, Penápolis e São José dos Campos, era baixa a frequência de realização desta tarefa, indicando um potencial a ser desenvolvido no sentido de elevar o rendimento da equipe de saúde bucal nessas localidades.

\section{TABELA 17}

Número e percentual do pessoal auxiliar que trabalha à quatro-mãos segundo a função e o sistema local de saúde, 1994.

\begin{tabular}{crcccc}
\hline & \multicolumn{5}{c}{ FUNÇÃO } \\
\cline { 2 - 6 } SILOS & \multicolumn{2}{c}{ ACD } & THD & \\
\hline Itú & $f$ & 83,9 & 7 & 100,0 \\
Embú & 26 & 38,5 & 1 & 10,0 \\
Penápolis & 5 & 18,2 & - & - \\
SJCampos/Centro & 2 & 12,5 & - & - \\
SJCampos/Norte & 2 & 10,0 & - & - \\
SJCampos/Sul & 1 & 21,4 & 1 & 3,8 \\
SJCampos/Leste & 31 & 16,6 & 1 & 4,8 \\
Campinas/Oeste & 1 & 96,0 & - & - \\
Campinas/Leste & 24 & 80,0 & - & - \\
Campinas/Norte & 12 & 75,0 & - & 10,92 \\
\hline TOTAL & 9 & 55,51 & 10 &
\end{tabular}

1: percentual calculado em relação à 153 ACDs

2: percentual calculado em relação à 92 THDs 
Em relação à algumas tarefas relativas à atividades individuais preventivas e curativas, a tabela 18 ilustra que estas tarefas eram muito pouco delegadas aos THDs. Aproximadamente $25 \%$ deles declararam realizar rotineiramente tais tarefas. Observa-se ainda, que a aplicação tópica de flúor, atividade atribuível aos THDs vinha também sendo delegada à cerca de $20 \%$ dos ACDs.

\section{TABELA 18}

Número e percentual do pessoal auxiliar que realiza tarefas na assistência individual segundo o tipo de atividade e a função. 1994

\begin{tabular}{crrrcc}
\hline & \multicolumn{5}{c}{ FUNÇÃo } \\
\cline { 2 - 6 } ATIVIDADE & \multicolumn{3}{c}{ ACD } & \multicolumn{3}{c}{ THD } \\
\hline aplicação tópica de flúor & f & & $\% 1$ & $f$ & $\% 2$ \\
aplicação de selante & 32 & 20,9 & 29 & 31,5 \\
aplicação de cariostático & 7 & 4,6 & 23 & 25,0 \\
polimento dentário & - & - & 17 & 18,5 \\
remoção de tártaro & 7 & 4,6 & 19 & 20,7 \\
inserção/condensação de mat. rest. & 4 & 2,6 & 23 & 25,0 \\
\hline
\end{tabular}

1: percentual calculado em relação à $153 \mathrm{ACDs}$

2. percentual calculado em relação à 92 THDs 
Ao desagregar os dados relativos à realização da atividade de aplicação tópica de flúor por município (tabela 19), verifica-se que, a pouca delegação dessa tarefa aos THDs (tabela 18), refere-se apenas àqueles empregados em $\mathrm{S}$. José do Campos, pois em Itú, Embú e Penápolis, 100\% dos THDs a realizam. Outro aspecto é que a delegação da atividade de aplicação tópica de flúor aos ACDs é muito mais frequente em Itú (66,6\%), quando comparado com as demais localidades.

\section{TABELA 19}

Número e percentual do pessoal auxiliar segundo a função e a realização de aplicação tópica de flúor na assistência individual por município, 1994.

\begin{tabular}{crcrcc}
\hline & \multicolumn{5}{c}{ FUNÇÃO } \\
\cline { 2 - 6 } MUNICÍPIO & \multicolumn{2}{c}{ ACD } & \multicolumn{1}{c}{ THD } \\
\hline Itú & $f 2$ & 66,6 & 7 & $\%$ \\
Embú & 3 & 23,1 & 10 & 100,0 \\
Penápolis & - & - & 6 & 100,0 \\
SJCampos & 1 & 2,2 & 6 & 8,7 \\
Campinas & 6 & 11,5 & - & - \\
\hline TOTAL & 32 & 20,91 & 29 & $31,5^{2}$ \\
\hline
\end{tabular}

1: percentual calculado em relação à 153 ACDs

2: percentual calculado em relação à 92 THDs

Uma descrição mais detalhada das atividades realizadas pelos THDs destas localidades pode ser encontrada nas tabelas 20 e 21 . A tabela 20 mostra que nos municípios de Embú e Penápolis, $100 \%$ dos THDs fazem aplicação de selante, cariostático e polimento dentário, enquanto no município de Itú, é baixo o percentual para a aplicação de cariostático e cerca de $57 \%$ dos THDs realizam polimento dentário. 
TABELA 20

Número e percentual de THDs que na assistência individual executam aplicação de selantes, aplicação de cariostáticos, e polimento dentário por município, 1994.

ATIVIDADES

aplicação de selantes aplicação de cariostático polimento dentário

\begin{tabular}{ccccccc} 
MUNICíPIO & N & $\%$ & N & $\%$ & N & $\%$ \\
\hline Itú & 7 & 100,0 & 1 & 14,3 & 4 & 57,1 \\
Embú & 10 & 100,0 & 10 & 100,0 & 9 & 90,0 \\
Penápolis & 6 & 100,0 & 6 & 100,0 & 6 & 100,0 \\
S. José dos Campos & - & - & - & - & - & - \\
\hline
\end{tabular}

Nota-se que no municipio de $\mathrm{S}$. José dos Campos, os THDs que atuam na assistência individual não realizam aplicação de selantes, cariostáticos e polimento dentário.

A tabela 21 revela, conforme já apontado anteriormente, que a delegação de tarefas relacionadas com a assistência odontológica individual é pouco explorada em $\mathrm{S}$. José dos Campos, quando comparado com os demais municípios com THD em exercício.

\section{TABELA 21}

Número e percentual de THDs que na assistência individual executam remoção de tártaro (RT), inserção e condensação de materiais restauradores (CR) por municipio, 1994.

\section{ATIVIDADES}

RT

CR

\begin{tabular}{ccccc} 
MUNICíPIO & N & $\%$ & N & $\%$ \\
\hline Itú & 7 & 100,0 & 7 & 100,0 \\
Embú & 10 & 100,0 & 10 & 100,0 \\
Penápolis & 6 & 100,0 & 6 & 100,0 \\
S. José dos Campos & - & - & 1 & 1,4 \\
\hline
\end{tabular}




\subsection{CARACTERISTICAS DA OPINIÃO}

Perguntou-se ao PAO, qual o grau de aceitação da população em relação às atividades de prevenção da cárie dentária realizadas por eles. Dos 245 respondentes, 33 $(13,5 \%)$ não tinham opinião, provavelmente por não realizarem ou por realizarem pouco estas atividades.

A tabela 22 mostra que a maioria do PAO considerou que a população aceita bem ou muito bem estas atividades. Cerca de $35,8 \%$ do PAO admitiu que a população aceita mais ou menos, ou aceita mal, ou ainda não aceita, revelando a necessidade de uma maior aproximação dos supervisores deste pessoal no sentido de buscar as hipóteses de explicação e as medidas possíveis para melhorar o desempenho do PAO nestas atividades.

\section{TABELA 22}

Distribuição do pessoal auxiliar segundo a opinião em relação à : " Durante as atividades de prevenção da cárie dentária (escovaçőes, bochechos, orientaçôes etc.) que você realiza, as pessoas que recebem essas atividades:". Frequência absoluta e acumulada, nos dez SILOS. 1994.

\begin{tabular}{ccc}
\hline OPINIÄO & N & $\%$ \\
\hline aceitam muito bem & 71 & 33,5 \\
aceitam bem & 65 & 30,7 \\
aceitam mais ou menos & 73 & 34,4 \\
aceitam mal & - & - \\
aceitam muito mal & 2 & 1,0 \\
não aceitam & 1 & 0,4 \\
\hline TOTAL & 212 & 100,0 \\
\hline
\end{tabular}


Quanto ao relacionamento profissional dos supervisores com o PAO (tabela 23), verificou-se que na opinião da maioria do PAO ( cerca de $90 \%$ ), o relacionamento é bom ou muito bom, indicando que existe um amplo espaço para o desenvolvimento de atividades de supervisão do PAO pelos dentistas.

\section{TABELA 23}

Distribuição do pessoal auxiliar segundo a opinião em relação à : " Você considera o relacionamento profissional dos dentistas com você: ".

Frequência absoluta e acumulada, em dez SILOS. 1994.

\begin{tabular}{ccc}
\hline OPINIÃO & N & $\%$ \\
\hline Muito bom & 155 & 63,3 \\
Bom & 65 & 26,5 \\
Nem bom, nem mau & 17 & 6,9 \\
Mau & 2 & 0,8 \\
Muito mau & - & - \\
Não tenho opinião & 1 & 0,4 \\
Não tenho relação com & 5 & 2,0 \\
dentistas no trabalho & 5 & 100,0 \\
\hline TOTAL & 245 &
\end{tabular}


A tabela 24 mostra que o PAO atribuiu aos dentistas, no que se refere às atividades de supervisão, um papel mais passivo. Metade do PAO considerou que os dentistas orientam o trabalho deles, sempre que solicitado, enquanto $39,0 \%$ admitiu que os dentistas observam, corrigem e orientam o trabalho, independente de solicitação.

\section{TABELA 24}

Distribuição do pessoal auxiliar segundo a opinião em relação à questão: " Durante o trabalho, os dentistas:". Em dez sistemas locais de saúde, 1994.

\begin{tabular}{cccc} 
OPINIÄO & $f$ & $\%$ & $\%^{*}$ \\
\hline $\begin{array}{c}\text { observam, corrigem e orientam } \\
\text { o seu trabalho }\end{array}$ & 92 & 37,7 & 39,0 \\
$\begin{array}{c}\text { orientam, sempre que você } \\
\text { solicita }\end{array}$ & 123 & 50,5 & 52,2 \\
$\begin{array}{c}\text { às vezes orientam quando você } \\
\text { solicita, às vezes não }\end{array}$ & 13 & 5,3 & 5,5 \\
$\quad \begin{array}{c}\text { dificilmente orientam } \\
\quad \text { nunca orientam }\end{array}$ & 2 & 0,8 & 0,8 \\
$\quad \begin{array}{c}\text { não tenho opinião } \\
\text { não tenho relação com dentistas no } \\
\text { trabalho }\end{array}$ & 6 & 2,5 & 2,5 \\
\hline
\end{tabular}

\%*: exclui não tenho opinião e não tenho relação com dentistas no trabalho 
A maioria do PAO no entanto (cerca de $70 \%$ ), considerou que os dentistas devem manter o grau de orientação atual e cerca de $25 \%$ admitiram que eles deveriam orientar mais o trabalho deles (tabela 25). Parece que o supervisionado prefere que a supervisão ocorra somente quando solicitada.

\section{TABELA 25}

Distribuição do pessoal auxiliar segundo a opinião em relação à : " você acha que os dentistas devem:". Em dez sistemas locais de saúde, 1994.

\begin{tabular}{crrr} 
OPINIÃO & $\mathrm{f}$ & $\%$ & \multicolumn{1}{c}{$\%^{*}$} \\
\hline orientar mais o seu trabalho & 61 & $\mathrm{~N}=244$ & \\
manter o grau de orientação atual & 171 & 70,1 & 72,8 \\
orientar menos o seu trabalho & 3 & 1,2 & 1,3 \\
deixar de orientar o seu trabalho & - & - & - \\
não tenho opinião & 9 & 3,7 & - \\
\hline
\end{tabular}

$\%^{*}$ : exclui não tenho opinião

A tabela 26 foi elaborada com a finalidade de comparar o percentual verificado somente nas duas primeiras opçðes de resposta das questðes das tabela 24 e 25 em cada municipio. Os resultados demonstram que a maioria do pessoal auxiliar de Campinas considerou que o supervisor orientava mais e que deveria manter esse grau de orientação. Ao contrário de Campinas, a maioria do pessoal de $\mathrm{S}$. José dos Campos considerou que os supervisores orientavam menos e que deveriam manter esse grau de orientação. O restante dos respondentes dos demais municipios, isto é, Itú, Embú e Penápolis, apresentaram percentuais de opinião muito próximos em uma ou outra questão. Por esta razão, considerase a comparação do resultado das questð̃es prejudicada, pois a proximidade dos percentuais diminui a consistência para demonstrar uma tendência marcada da opinião do pessoal auxiliar nesses municipios. 
Neste sentido, os dados permitem considerar que o papel do supervisor parece melhor compreendido entre o pessoal do municipio de Campinas que de S. José do Campos, nāo podendo-se tirar conclusôes sobre o pessoal dos demais municipios.

\section{TABELA 26}

Opiniāo do pessoal auxiliar sobre o comportamento dos dentistas (CDs) durante as atividades de supervisão, e sua expectativa segundo o municipio, 1994.

\begin{tabular}{lcccc}
\hline & \multicolumn{2}{c}{ COMPORTAMENTO DOS CDS } & \multicolumn{2}{c}{ EXPECTATIVA DO PAO } \\
\cline { 2 - 5 } \multicolumn{1}{c}{ MUNICIPIO } & $\begin{array}{c}\text { orientam } \\
\text { mais } \\
\%\end{array}$ & $\begin{array}{c}\text { orientam } \\
\text { menos }\end{array}$ & $\begin{array}{c}\text { aumentar } \\
\text { orientação }\end{array}$ & $\begin{array}{c}\text { diminuir } \\
\text { orientação } \\
\%\end{array}$ \\
\hline Itú & 23,7 & $\%$ & 39,5 & 44,7 \\
Embú & 43,5 & 44,7 & 26,1 & 69,6 \\
Penápolis & 47,1 & 56,5 & 35,3 & 58,8 \\
S. José dos Campos & 30,4 & 52,9 & 16,5 & 80,9 \\
Campinas & 57,7 & 58,3 & 28,8 & 67,3 \\
\hline
\end{tabular}

Quanto à opiniāo do PAO sobre o relacionamento profissional com outros auxiliares, $11,8 \%$ dos respondentes não manifestaram opinião, ou por não terem opinião ou por não terem relação com outros auxiliares no trabalho,. Dos que expressaram opiniāo, a maioria do PAO $(88,0 \%)$ considerou que o relacionamento profissional com outros auxiliares é bom ou muito bom (tabela 27).

\section{TABELA 27}

Distribuição do pessoal auxiliar segundo a opinião em relação à questão: " Você considera o relacionamento profissional de outros auxiliares com você:". Em dez SILOS,1994.

\begin{tabular}{ccc}
\hline OPINIĀO & $f$ & $\%$ \\
\hline Muito bom & 81 & 37,5 \\
Bom & 109 & 50,5 \\
Nem bom, nem mau & 24 & 11,1 \\
Mau & 2 & 0,9 \\
Muito mau & - & - \\
\hline TOTAL & 216 & 100,0 \\
\hline
\end{tabular}


Quanto ao grau de cooperação existente entre o auxiliares durante o trabalho, a maioria do PAO $(60,3 \%)$ manifestou opinião de que os auxiliares dividem bem o trabalho, tem ótima cooperação ou raramente um trabalha mais que o outro. $32,0 \%$ afirmaram que às vezes um trabalha mais que o outro. Além disso, cabe ressaltar que $28,2 \%$ não informaram ou informaram não ter opiniāo ou não ter relação com outros auxiliares no trabalho (tabela 28).

\section{TABELA 28}

Distribuição do pessoal auxiliar segundo a opinião em relação à questão: " Durante o trabalho, os auxiliares:". Frequência absoluta e acumulada em dez SILOS, 1994.

\begin{tabular}{ccc}
\hline OPINIÃO & N & $\%$ \\
\hline $\begin{array}{c}\text { dividem bem o trabalho entre si, } \\
\text { tem ótima cooperação }\end{array}$ & 82 & 46,7 \\
$\begin{array}{c}\text { raramente um trabalha mais que } \\
\text { outro }\end{array}$ & 24 & 13,6 \\
$\begin{array}{c}\text { às vezes um trabalha mais que } \\
\text { outro }\end{array}$ & 56 & 31,8 \\
$\begin{array}{c}\text { frequentemente um trabalha mais } \\
\text { que outro }\end{array}$ & 9 & 5,1 \\
$\begin{array}{c}\text { não há cooperação, sempre um } \\
\text { trabalha mais que outro }\end{array}$ & 5 & 2,8 \\
\hline$\quad$ TOTAL & 176 & 100,0 \\
\hline
\end{tabular}


Por último, foi perguntado ao $\mathrm{PAO}$, qual sua opinião em relação à finalidade principal do seu trabalho. De acordo com os termos do enunciado da questão, $22 \%$ do PAO declarou não ter opinião. Dos que expressaram um conceito, a tabela 29 revela que uma maioria relativa do PAO $(62,8 \%)$ considerou que "deve-se aumentar o número de auxiliares para fazer mais atividades de prevenção fora dos consultórios", mostrando que começa a se desenvolver no PAO a noção que atribui maior importância às açð̌es coletivas em relação às açðes de assistência odontológica individual.

\section{TABELA 29}

Distribuição do pessoal auxiliar segundo a opinião em relação à questão: " Deve-se aumentar o número de auxiliares para: ". Em dez sistemas locais de saúde, 1994.

\begin{tabular}{|c|c|c|}
\hline OPINIĀO & $\mathrm{N}$ & $\%$ \\
\hline auxiliar mais os dentistas nos consultórios & 71 & 37,2 \\
\hline $\begin{array}{l}\text { fazer mais atividades de prevenção fora dos } \\
\text { consultórios }\end{array}$ & 120 & 62,8 \\
\hline TOTAL & 191 & 100,0 \\
\hline
\end{tabular}

Ao distribuir os dados pelos municípios, observa-se que a opinião do PAO de Itú, Penápolis e Campinas, é mais favorável às atividades coletivas do que o PAO dos municipios de Embú e São José dos Campos, cujas respostas demonstram certo equilíbrio (tabela 30).

Este resultado pode indicar, quando relacionado às informaçð̄es de tempo estimado dispendido em açð̄es coletivas, que o PAO nos municípios de Itú, Penápolis e Campinas, conhece a necessidade de incrementar açóes coletivas de prevenção em saúde bucal à população dessas localidades. Os resultados da opinião do PAO em Embú e S. José dos Campos indicam a opção por um certo equilíbrio entre os dois tipos de atividades. 
Tal situação pode ser atribuida, dentre outros aspectos, a um certo equilibrio que foi observado no gasto de tempo da jornada de trabalho do PAO dispendido com ações coletivas e com ações de assistência odontológica individual no período da aplicação do questionário.

\section{TABELA 30}

Distribuição do pessoal auxiliar segundo a opinião em relação à questão: " Deve-se aumentar o número de auxiliares para: "e o município, 1994. Freq. absoluta e relativa. OPINIÃO

\begin{tabular}{lcccc}
\cline { 2 - 5 } & \multicolumn{2}{c}{$\begin{array}{c}\text { Auxiliar mais os CDs nos } \\
\text { consultórios }\end{array}$} & \multicolumn{2}{c}{$\begin{array}{c}\text { Fazer mais atividades de } \\
\text { prevenção fora dos consultórios }\end{array}$} \\
\hline MUNICíPIO & $\mathrm{N}$ & $\%$ & $\mathrm{~N}$ & $\%$ \\
\hline Itú & 10 & 33,3 & 20 & 66,7 \\
Embú & 11 & 47,8 & 12 & 52,2 \\
Penápolis & 2 & 15,4 & 11 & 84,6 \\
S. J. dos Campos & 34 & 45,9 & 40 & 54,1 \\
Campinas & 14 & 27,5 & 37 & 72,5 \\
\hline
\end{tabular}




\section{DISCUSSÃO}

O PAO empregado nos municípios de Itú, Embú, Penápolis, São José dos Campos e Campinas é, em sua grande maioria, do sexo feminino (92,7\%). É, também, predominantemente jovem com idade entre 17 e 37 anos. A proporção de mulheres é semelhante à encontrada por BOTTI ${ }^{4}$ em 1977 em Santa Maria, Rio Grande do Sul.

Apresenta um nível de escolaridade que pode ser considerado elevado quando comparado com as estimativas admitidas nos serviços de saúde no Brasil e reconhecendo-se o fato de o sistema educacional brasileiro ser ainda marcadamente excludente ${ }^{36}$ (somente $9 \%$ dos ingressantes no ciclo básico completam o $2^{\circ} \mathrm{grau}$ ).

Cerca de $95 \%$ do PAO pesquisado possuem o $1^{\circ}$ grau completo e $70 \%$ já concluiram os estudos secundários. Estes percentuais são maiores que os revelados em recente relatório divulgado pela Secretaria Municipal da Saúde de São Paulo, importante instituição de saúde no Brasil, segundo o qual dos 1972 atendentes de enfermagem pesquisados, apenas $49,3 \%$ tinham $01^{\circ}$ grau completo e $10,7 \%$ declararam ter concluído o $2^{\circ} \mathrm{grau}^{44}$.

Quanto à formação especifica observa-se que, em geral, a proporção de PAO com qualificação profissional é mais alta entre os que exercem funçð̋es de ACD $(61,4 \%)$, do que entre os que exercem funçø̃es de THD (25\%). Esta situação indica que, geralmente esse pessoal encontra mais facilidades para qualificar-se como $A C D$, cujo curso é mais curto, exige pré-requisitos de admissão mais favoráveis às suas características, tem menor custo e é de mais fácil aceitação pelas instituiçðes de saúde, do que o curso de THD, mais longo e com conteúdos e práticas mais complexas.

$\grave{A}$ despeito desta condição mais geral, observa-se entre os que exercem funçð̋es de THD, alta frequência de qualificação nos municípios de Itú, Embú e Penápolis, e baixa frequência em São José dos Campos. Esta diferença pode ser resultado da adoção de distintas estratégias de preparação do pessoal auxiliar odontológico verificadas durante a década dos oitenta, e que visavam produzir modificaçøes na organização da atenção à saúde bucal dos sistemas de saúde. No início da década, não haviam cursos e a decisão recaía quase sempre na estratégia do treinamento em serviço. No final dos anos oitenta, 
com o desenvolvimento de mecanismos de articulação entre os sistemas de saúde e de educação, tornou-se mais viável e factível a adoção da estratégia da formação em serviço.

Os percentuais de PAO que declararam ter concluído ou estar realizando sua formação especifica demonstram que existe, de fato, um esforço por parte dos trabalhadores e dos municipios pesquisados no sentido de cumprir as diretrizes de saúde bucal do SUS-SP. Cumpre enfatizar que, face aos resultados obtidos, o sistema municipal de saúde de São José dos Campos (SMS-SJC) é o sistema que possui maior número de ACDs e THDs empregados. Nesse município, entre os que exercem funçбes de THD, nenhum havia concluido curso de qualificação profissional e $9(13 \%)$ estavam cursando. Este fato sugere que, considerando sua importancia regional, seu porte e capacidade de intervenção, o SMS-SJC deveria agregar mais esforços e recursos, além dos já dispendidos, na estruturação adequada de cursos de qualificação profissional, atividade de expressivo interesse do pessoal $(80 \%)$ e que pode elevar a qualidade das ações de atenção à saúde bucal dirigidas à população.

De modo geral, é significativo o interesse dos respondentes em participar de cursos de formação de ACD ou THD. Tal interesse aumenta a importância das atividades de desenvolvimento e formação de recursos humanos planejadas no âmbito do SUS. Neste aspecto, conferências e seminários do setor saúde tem afirmado, reiteradamente, a necessidade da implementaçăo dessas atividades de forma bem planejada a fim de se elevar a qualidade e o rendimento das açoes e serviços de saúde ${ }^{12}$. Consideram, ainda, que os SILOS devem preparar técnicos para estruturar projetos que articulem estas atividades a açóes de saúde compatíveis com as necessidades da populaçăo sendo que, uma das estratégias fundamentais é a integração ensino-serviço tendo como eixo o processo de trabalho, à exemplo do que realiza o "Projeto Larga Escala", Programa de Formação de Recursos Humanos de Níveis Médio e Elementar para os Serviços de Saúde criado no início da década de oitenta, em âmbito nacional. Desta forma, combina-se o interesse do trabalhador com o interesse da instituição e as necessidades da população. 
Em relação às caracteristicas do emprego, o PAO apresenta, majoritariamente, vinculo municipal. Este resultado confirma tendência verificada no setor público em estudos anteriores de NOGUEIRA ${ }^{32}$, BOTAZZO $^{3}$ e TOLEDO ${ }^{50}$.

Em geral, trabalham 40 horas/semana e recebem em média US $\$ 215,30$ no exercício da função de ACD e US $\$ 220,00$ como THD. A variação de salário recebido é maior entre os ACDs que entre os THDs. Dos municípios, Penápolis, Itú e Embú propiciam menor remuneração: para ACDs, cerca de US $\$ 120,00$, e para THDs cerca de US $\$ 185,00$. Campinas e $\mathrm{S}$. José dos Campos apresentam maiores médias salariais: os ACDs recebem US $\$ 330,00$ e US $\$ 198,00$ respectivamente, e os THDs de $S$. José dos Campos informaram receber US $\$ 232,00$.

Os THDs dos municipios de Embú e Penápolis têm média salarial aproximadamente $50 \%$ maior que a média dos ACDs destes municipios. Entretanto, nos municipios de ltú e São José dos Campos, a diferença é de $26 \%$ e $15 \%$ respectivamente, o que indica nestes municípios a necessidade da realização de estudos visando eventuais ajustes quanto aos critérios de diferença salarial entre o pessoal de niveis básico e médio. Tal procedimento pode contribuir para um melhor resultado do plano de cargos e salários com consequências positivas no desenvolvimento organizacional da instituição de saúde.

Do ponto de vista da distribuição de horas-trabalho do PAO entre unidades básicas de saúde e escolas/espaços sociais, observa-se um certo equilibrio em seis SILOS. Os SILOS norte, sul e leste de SJC apresenta maior percentual de horas-trabalho em escolas/espaços sociais e o SILOS leste de Campinas maior percentual em unidades básicas de saúde.

Em relação à participação do $\mathrm{PAO}$ nas açðes coletivas, verifica-se na maioria dos SILOS que essa participação è maior quando se trata da realização dessas atividades em escolas/espaços sociais, confirmando experiências e diretrizes oficiais de odontologia em saúde coletiva. No entanto, deve-se ressaltar também, que os resultados revelam que o PAO de Itú, Embú e Penápolis desenvolvem de forma significativa atividades de evidenciação de placa seguida de escovação supervisionada em unidades básicas de saúde. Esse aspecto é muito importante, pois aumenta a qualidade do serviço odontológico 
oferecido e atinge diferentes grupos populacionais que frequentam unidades de saúde com atividades de promoção da saúde bucal.

De modo geral, percebe-se que o rendimento médio está abaixo do esperado quando comparado com o rendimento potencial de um auxiliar realizando somente a atividade indicada durante $\mathbf{4 0}$ horas por semana. Isto sugere que a jornada de trabalho do PAO não é dispendida em uma ou duas atividades mas num conjunto de atividades que incluem desde tarefas no campo das ações coletivas quanto das açōes de assistência odontológica individual. Cumpre enfatizar que os resultados verificados em escolas/espaços sociais do PAO dos SILOS norte e leste de São José dos Campos e em unidades de saúde do PAO dos SILOS de Embú, ao contrário dos demais SILOS, estão bem próximos do esperado conforme o critério adotado.

Os resultados podem sugerir também que os parâmetros de planejamento e supervisão do trabalho do PAO aplicados nos dez SILOS apresentam mais diferenças do que semelhanças. Além disso, parecem indicar que existem insuficiências qualiquantitativas desse pessoal nos SILOS. Deve-se considerar ainda que, provavelmente, dado ser um conjunto de atividades de implementação recente, existem muitos aspectos relativos às açóes coletivas preventivas e educativas em saúde bucal a serem desenvolvidos tanto com o PAO quanto com os supervisores dessas ações.

Observa-se, em todos os municípios investigados, maior envolvimento com atividades educativas e atividades do tipo evidenciação de placa bacteriana seguida de escovaçăo supervisionada. Em segundo lugar, verifica-se grande participação no provimento de bochechos fluorados, excetuando-se o município de Campinas, cuja atividade é realizada por pessoal vinculado à outros setores da administração pública.

Em relação à atividade de aplicação de flúor com escova ou moldeira, nota-se significativa participaçăo somente nos municípios de Embú e São José dos Campos. Este aspecto parece sugerir que os municipios de Itú, Penápolis e Campinas deveriam proceder estudos em sua programação a fim de avaliar, tanto do ponto de vista epidemiológico como do ponto de vista social e económico, a pertinéncia da implementaçăo deste tipo de açăo 
coletiva em grupos de alto risco, dado serem conhecidos os benefícios do uso racional de produtos fluorados.

De fato, na última década, vários analistas ${ }^{1,3,8,14,27,37,38,40,43,45,50}$ em conferências, seminários, congressos e publicaçð̌es, têm reiterado que para melhorar os niveis de saúde bucal, dentre outros aspectos, deve-se perseguir, dois objetivos estratégicos: aumentar, de um lado, as medidas de prevenção e promoção da saúde bucal e, de outro, incorporar e preparar PAO nos serviços de saúde. Em documentos oficiais de políticas de saúde bucal aparecem, invariavelmente, proposiçరes semelhantes.

Os resultados obtidos com a participaçăo do PAO em açóes coletivas revelam que esforços nesse sentido vêm sendo desenvolvidos, em diferentes graus, nos municípios investigados, destacando-se principalmente os SILOS do Embú e das regióes norte e leste de S. José do Campos. Nesses SILOS, os dados obtidos permitem alcançar estimativas que demonstram que o PAO vem dedicando sua jornada de trabalho mais para açóes coletivas que para açóes de assistência odontológica individual, contribuindo deste modo, para a transformação das práticas da odontologia em saúde coletiva e para a mudança do modelo assistencial conforme as diretrizes de saúde bucal e os princípios do SUS.

Os resultados nessas localidades estão próximos ao encontrado por DEAL ${ }^{16}$ em relação à 356 higienistas dentais empregados em programas de saúde pública nos Estados Unidos.

O exposto permite corroborar a hipótese $\left(\mathrm{H}_{2}\right)$, segundo a qual "a proporção estimada de tempo da jornada de trabalho do PAO na execução de atividades ou procedimentos coletivos é influenciada pelo SILOS que emprega o PAO".

Quanto à hipótese $\left(\mathrm{H}_{1}\right)$ segundo a qual "a proporção estimada de tempo da jornada de trabalho do PAO na execução de atividades ou procedimentos coletivos é menor que a proporção de tempo dedicada à atividades ou procedimentos individuais", pode-se afirmar que, enquanto os SILOS de Itú, Penápolis, Campinas, centro e sul de S. José dos Campos estão em concordância, os SILOS do Embú, norte e leste de S. José dos Campos não a sustentam. 
Pode-se afirmar ainda que, na alteração das práticas da odontologia em saúde coletiva e do modelo assistencial preconizadas por diretrizes oficiais e que indicam a necessidade de maior desenvolvimento de atividades coletivas no sentido da promoção da saúde bucal no âmbito do SUS, o municipio e o SILOS desempenham papel decisivo, sendo que o PAO é estratégico nesse processo.

Quanto à participação do PAO na assistência odontológica individual cabe ressaltar que mais da metade dos THDs vêm exercendo também tarefas típicas de ACDs, 0 que pode indicar que existem insuficiências quali-quantitativas de PAO nos municípios pesquisados. São exemplos dessas tarefas a preparação da sala, a limpeza, desinfecção e esterilização dos instrumentos e 0 preparo de cimentos e outros materiais durante 0 atendimento clínico de pacientes.

Excetuando-se ltú e Campinas, é baixa a proporção de PAO que trabalha à quatro-mãos rotineiramente. Este resultado permite afirmar que o rendimento da equipe de saúde bucal, provavelmente, é maior em ltú e Campinas que nos demais municípios. Além disso, em Embú, Penápolis e São José dos Campos, dado que o pessoal se encontra disponivel, existem possibilidades mais imediatas de elevar-se o rendimento das equipes de saúde bucal através da incorporação e da preparação de ACDs em tarefas de instrumentação do campo operatório.

No que se refere à delegação de funçठ̌es, cerca de $20 \%$ dos ACDs declararam estar realizando aplicaçăo tópica de flúor, e a maioria dos THDs dos municípios de Itú, Embú e Penápolis informaram realizar a aplicaçăo tópica de substâncias para prevençăo da cárie dentária (selante, flúor e cariostático), polimento coronário, remoçăo de tártaro, e inserção/condensação de materiais restauradores. É pequena a participação dos THDs do município de $\mathrm{S}$. José dos Campos em tarefas relacionadas com o provimento de procedimentos individuais preventivos e curativos na assistência odontológica. Somente $13 \%$ dos THDs das regióes centro e norte de $S$. José dos Campos declararam realizar aplicação tópica de flúor na assistência individual.

Quanto à assistência individual, as informaçóes produzidas demonstram que os municipios utilizam o PAO, principalmente os THDs, de forma distinta. Os resultados 
indicam que, consideradas as características de cada SILOS, os municípios de Itú, Embú e Penápolis apresentam maior grau de delegação de funçóes aos THDs relacionadas com a assistência odontológica individual do que os municípios de $S$. José dos Campos e Campinas.

Campinas não emprega PAO do tipo THD. Emprega apenas ACDs e possui uma relaçăo CD/PAO de 1:0,8. Com os resultados encontrados, pode-se afirmar que, comparativamente aos demais sistemas, as ações de saúde bucal concentram-se, de modo geral, na assistência odontológica individual e no cirurgiăo-dentista enquanto sujeito do processo de trabalho. É um modelo de prática de baixa cobertura e de alto custo social.

No caso de $\mathrm{S}$. José dos Campos, argumenta-se que os THDs dedicam-se prioritariamente para as açōes coletivas, o que é muito relevante. De fato, as informações produzidas revelam que os THDs empregados nesse município realizam açöes coletivas, mas indicam também que realizam tarefas típicas de ACDs, principalmente, preparação da sala para o atendimento, limpeza e desinfecção dos materiais, e preparaçăo de cimentos e produtos utilizados na assistência odontológica individual.

Ao contrário de Campinas, o sujeito do processo de trabalho é uma equipe e existe um considerável esforço dispendido em atividades de promoção da saúde bucal em escolas/espaços sociais. Pode-se considerar também, que a expansão do grau de delegação de funções aos THDs dependerá em grande medida de uma melhor relação CD/PAO, que no momento da pesquisa era de 1:1,7, o que significa aumento do número de trabalhadores de nível auxiliar, e da decisão de ampliar a cobertura e diminuir os custos operacionais dos serviços oferecidos de modo a alcançar principalmente os grupos populacionais que frequentam unidades básicas de saúde.

De modo similar, regióes e países utilizam o PAO de forma diferenciada. Enquanto no Reino Unido, segundo ROCK \& BRADNOCK ${ }^{39}$, os dentistas delegavam aos HD mais atividades de raspagem e polimento coronário, JANCZUK ${ }^{22}$ verificou que, na Polônia, cerca de $45 \%$ dos HD realizavam atividades de educação em saúde bucal e de profilaxia com flúor, e somente $25 \%$, atividades de tartarectomia e inserção de amálgama. AXELSSON ${ }^{1}$ informou que, na Suécia, os higienistas dentais săo utilizados, dentre outros 
aspectos, para incrementar o autocuidado de indivíduos e grupos, realizar procedimentos de raspagem e alisamento radicular, limpeza mecânica profissional, aplicação de testes salivares, de géis, vernizes e selantes fluorados, acabamento de restauraçбes, remoção de excessos/saliências, e orientação de dieta.

Quanto às questరes formuladas ao PAO a fim de se conhecer sua opinião sobre temas como aceitação da população, relacionamento profissional, supervisão técnica, cooperação no trabalho e papel nos programas de saúde pública, a maioria do PAO considera que a população aceita bem ou muito bem os seus serviços, reagindo positivamente. Resultados semelhantes foram obtidos por JANCZUK ${ }^{22}$, STEELE ${ }^{48}$, e UITENBROEK e col. ${ }^{51}$.

$\mathrm{Na}$ opinião do $\mathrm{PAO}$, os $\mathrm{CDs}$ têm um relacionamento profissional bom ou muito bom com eles, prestam orientaçठ́es sempre que necessário e devem manter o grau de orientação atual. Além disso, os resultados permitem concluir que o papel do supervisor parece melhor compreendido entre o PAO do município de Campinas que no de $\mathrm{S}$. José dos Campos, não havendo uma tendência marcada nos demais municípios.

O PAO considera que o relacionamento profissional com outros auxiliares é bom ou muito bom, que dividem bem o trabalho e raramente um trabalha mais que o outro. Observa-se também que a atribuição de maior relevância às açôes coletivas de promoção da saúde bucal em relação às açoes de assistência odontológica individual, é uma noção presente no PAO dos SILOS estudados.

Tais resultados demonstram que o PAO é um trabalhador da saúde, portador de conhecimentos e práticas que devem ser levados em consideração por supervisores e administradores de serviços públicos odontológicos. Nesta condição, ele é um sujeito coletivo muito importante para a alteração das práticas da odontologia em saúde coletiva no sentido da promoção da saúde bucal.

Cabe finalmente destacar que alguns resultados sugerem a necessidade de se desenvolver atividades de educaçăo permanente, a fim de permitir ao PAO, e em consequência às equipes de trabalho, a reflexão e a compreensăo de aspectos relativos ao comportamento da população, ao trabalho em equipe, à supervisão técnica e à qualidade 
nas açð̄es e serviços de saúde. Este aspecto coincide com necessidades identificadas em reuniós e conferências de especialistas da área que propóem para os currículos de habilitação do pessoal de nível médio, a inclusão de conteúdos que permitam a leitura social da realidade como educação em saúde, informaçăo sobre o SUS, epidemiologia, antropologia e sociologia, além daqueles inerentes às atribuições específicas de cada habilitação ${ }^{12}$.

Admitindo-se que aproximadamente 3 mil trabalhadores vêm exercendo funçðes auxiliares nos serviços públicos odontológicos do SUS-SP ${ }^{50}$, cabe assinalar que esta pesquisa permitiu conhecer aspectos relativos a cerca de $10 \%$ deles, empregados em sistemas de saúde de referência para os demais programas municipais de saúde bucal. Não é possivel, dada as características metodológicas do presente estudo, generalizar os resultados obtidos, os quais evidenciaram que a participação do PAO nas ações de promoção da saúde bucal é relativa e varia conforme o SILOS em estudo. 


\section{CONCLUSÕES}

Analisando a participação do pessoal auxiliar odontológico em dez SILOS de cinco municípios do Estado de São Paulo, pode-se concluir que:

1. Sua participação em atividades de promoção da saúde bucal é relativa e varia conforme - SILOS em estudo;

2. A maioria do PAO empregado nos dez SILOS é jovem, do sexo feminino, possui $2^{\circ}$ grau completo, qualificação profissional em nível de auxiliar ou de técnico, tem vínculo municipal e trabalha 40 horas/semana, sendo que, recebem entre US $\$ 119,00$ (Itú) e US $\$ 330,00$ (Campinas) no exercício da função de ACD, e entre US $\$ 162,00$ (Itú) e US $\$ 232,00$ (S. José dos Campos) como THD.

3. Dentre as ações coletivas pesquisadas, a participação do PAO é mais frequente em atividades de evidenciação de placa bacteriana seguida de escovação supervisionada, bochechos fluorados e atividades educativas;

4. Na maioria dos SILOS, essa participação em ações coletivas é maior quando se trata da realização dessas atividades em escolas ou outros espaços sociais.

5. Em Itú, Embú e Penápolis, o pessoal auxiliar desenvolve de forma significativa atividades de evidenciação de placa seguida de escovação supervisionada em unidades básicas de saúde, atingindo com atividades de promoção da saúde bucal grupos populacionais que frequentam unidades de saúde.

6. Nos SILOS do Embú e das regióes norte e leste de S. José do Campos, o PAO vem dedicando sua jornada de trabalho mais para açס̄es coletivas que para açðes de assistência odontológica individual, contribuindo deste modo, para a transformação das práticas da odontologia em saúde coletiva e para a mudança do modelo assistencial conforme as diretrizes de saúde bucal e os princípios do SUS.

7. Excetuando-se os três SILOS de Campinas e o de Itú, é baixa a proporção do PAO que trabalha à quatro-mãos rotineiramente;

8. Os SILOS de Itú, Embú e Penápolis apresentam maior grau de delegação de funções relacionadas com tarefas em ações de assistência odontológica individual que os SILOS dos municípios de São José dos Campos e Campinas;

9. Segundo o pessoal auxiliar, a população-usuária reage positivamente e aceita bem os seus serviços. Além disso, os CDs têm um relacionamento profissional bom ou muito bom com eles, prestam orientações sempre que necessário e devem manter o grau de orientação atual. 


\section{CONSIDERAÇÕES FINAIS}

Desde o final dos anos 70 e início dos anos 80 , o sistema de saúde no Brasil passou por profundas alterações nos aspectos júridico-normativos, na estrutura organizacional e nas práticas de saúde. No contexto deste processo de Reforma Sanitária, no Estado de São Paulo, esforços foram desenvolvidos no sentido da estruturação de sistemas locais de saúde e da universalização da atenção à saúde bucal sob os princípios gerais do Sistema Único de Saúde.

Se de um lado, ainda é grande a participação desse pessoal em ações relacionadas com a assistência odontológica individual, característica do modelo de prática odontológica predominante, por outro, em alguns SILOS, entre eles, as regiões norte e leste de S. José dos Campos e o SILOS de Embú, essa participação é maior em ações coletivas de promoção da saúde bucal e confirma o papel estratégico do pessoal auxiliar neste processo.

Nessa pesquisa considerou-se o pessoal auxiliar, não somente na sua dimensão de trabalhador da saúde, mas também como um sujeito coletivo, portador de conhecimentos e práticas que devem ser levados em consideração por supervisores e administradores de serviços públicos odontológicos.

Frente aos resultados observados, cabe sugerir também que:

1. Os SILOS pesquisados incrementem medidas de profissionalização, valorizaçăo e participação dos trabalhadores da saúde, e prossigam no desenvolvimento de atividades de educação permanente do PAO e das equipes de saúde bucal;

2. A participação do PAO em ações de promoção da saúde bucal seja ampliada no domínio das técnicas de aplicação de flúor com escova ou moldeira na maioria dos SILOS;

3. Os SILOS de ltú e do município de São José dos Campos realizem estudos visando, se necessário, ajustes nos critérios de diferença salarial entre o pessoal de níveis básico e médio, uma vez que tal procedimento pode contribuir para um melhor resultado do plano de cargos e salários e trazer consequências positivas no desenvolvimento organizacional da instituição de saúde;

4. Nos SILOS de Embú, Penápolis e nas quatro regiōes do município de São José dos Campos seja elevado o rendimento das atividades individuais através da implementação das técnicas de trabalho à quatro-mãos;

5. Nos SILOS de S. José dos Campos, a participação do PAO em unidades básicas de saúde seja ampliada;

6. Nos SILOS de Campinas, a participação do PAO em ações coletivas de promoção da saúde bucal seja ampliada. 
Ao final dessa pesquisa, espera-se que este esforço estimule 0 desenvolvimento de novos estudos sobre o tema em diferentes localidades, e que as informações produzidas possam deslocar a atenção de professores e instrutores de cursos de pessoal auxiliar odontológico, de técnicos e administradores da área, para o papel que, conforme foi demonstrado, está reservado a esse trabalhador na universalização da atenção à saúde bucal, na estruturação dos SILOS e na construção do SUS. 


\section{REFERÊNCIAS BIBLIOGRÁFICAS}

01.AXELSSON, P.; ROLANDSSON, M.; BJERNER, B. How swedish dental hygienists apply their training program in the field. Community Dent. Oral Epidemiol., 21:297-302, 1993.

02.BADER. J.D.; KAPLAN, A.L.; LANGE, K.W.; MULLINS, M.R. Prodution and economic contributions of dental hygienists. J. Public Health Dent., 44:28-34, 1984.

03.BOTAZZO, C.; MANFREDINI, M. A.; NARVAI, P.C. Força de trabalho em saúde bucal. Rev. Saúde Debate, 24:74-7, 1989.

04.BOTTI, M.R.V. Análise do posicionamento dos cirurgiôes-dentistas do município de Santa Maria-RS, quanto à aspectos relacionados a pessoal auxiliar em odontologia. Porto Alegre, UFRGS, 1978.

05.BRASIL. Leis, etc. Lei 8.080 , de 19 de setembro de 1990. Diário Oficial da União, Brasilia, 20 set. 1990.

06.BRASIL. MINISTÉRIO DA SAÚDE/MINISTÉRIO DA PREVIDÊNCIA E ASSISTÉNCIA SOCIAL. Programa nacional de serviços básicos de saúde. Brasília, Centro de Documentação do MS, 1980.

07.BRASIL. MINISTÉRIO DA PREVIDÊNCIA E ASSISTÊNCIA SOCIAL. Reorientação da assistência médica no âmbito da previdéncia social. Brasília, INAMPS, 1983.

08.CHAVES, M. M. Odontologia social. Rio de Janeiro, Artes Médicas, 1986.

09.CIRINCIONE, U.K. \& WILS, W.J. Survey of dental hygienists in the hospital setting. J.

Dent. Hyg., 64:239-45, 1990.

10.COHEN, L.; SINGER, J.; LABELLE, A. Characteristics of employment and job satisfation in nontraditional dental hygiene practice settings. J. Public Health Dent., 47:88-93, 1987.

11.CONFERÉNCIA INTERNACIONAL SOBRE CUIDADOS PRIMÁRIOS DE SAÚDE, AIma Ata, 1978. Relatório. Brasilia,UNICEF-Brasil, 1979.

12.CONFERÊNCIA NACIONAL DE RECURSOS HUMANOS PARA A SAÚDE, $2^{\mathrm{a}}$, Brasília, 1993. Relatório final. Cad. RH Saúde, 2 (1):7-30, 1994.

13.CONFERÉNCIA NACIONAL DE SAÚDE, $8^{\mathrm{a}}$, Brasília, 1986. Relatório final. Brasilia, Centro de Documentação do MS, 1986.

14.CONFERÉNCIA NACIONAL DE SAÚDE BUCAL, 1", Brasília, 1986. Relatório final. Brasília, Centro de Documentação do MS, 1986. 
15.CONFERÉNCIA NACIONAL DE SAÚDE, $9^{\mathrm{a}}$, Brasília, 1992. Relatório final. Brasilia, Centro de Documentação do MS, 1992.

16.DEAL, T. S. The role of dental hygienists en state public health programs. J. Dent. Hyg., 64:286-9, 1990.

17.DONNANGELO, M. C. F. \& PEREIRA, L. Saúde e sociedade. São Paulo, Duas Cidades, 1976.

18.FREIRE, P.S. \& LOURES, O.F. Organização de um programa dentário escolar em base incremental. Rev. Serv. Esp. de Saúde Pública, 9:307-25, 1957.

19.FULTON, J. T. Experiment in dental care, results of New Zeland's use of school dental nurses. Geneva, World Health Organization, 1951.

20.GIRARDI, S. N. O perfil do "emprego" em saúde no Brasil. Brasília, Ministério da Saúde, 1986.

21.HIRANO, S., org. Pesquisa social: projeto e planejamento. São Paulo, T. A. Queiroz, 1979. p.81

22.JANCZUK, A. Dental hygienists in Poland. Community Dent. Oral Epidemiol., 6:283-5, 1978.

23.LEITE, I. N. \& PINTO, V. G. Odontologia: um mercado cativo ? A profissionalização à nivel médio e elementar. RGO, 31(1):41-46, 1983.

24.LOURES, O.F. \& FREIRE, P.S. Utilizaçăo efetiva de pessoal auxiliar de odontologia sanitária. Brasília, FSESP, 1964.

25.MEJIA, A. Educacion contínua. Educ. Med. Salud, 20:43-69, 1986.

26.MOSER, C.A. \& KALTON, G. Survey methods in social investigation. London, Heinemann Educational Books, 1971. p.303-47.

27.NARVAI, P.C.; MANFREDINI, M.A.; BOTAZZO, C.; RAINERI, N.; SCHNEIDER FILHO, D.A.; FRAZÃO, P. Contra o técnico em higiene dental. Rev. Saúde Debate, 28:5965, 1990.

28.NARVAl, P.C. Saúde bucal: assistência ou atenção ? São Paulo, 1992.

29.NASH, K.D.; DOUGLASS, C.W.; WILSON, J. Economics of scale and productivity in dental practices. Chapel Hill, NC: Research Triangle Institute, 1979.

30.NOGUEIRA, R.P. Pessoal de saúde: a discussão teórica e a produção científica sobre o tema. In: Organização Panamericana de Saúde. As ciências sociais em saúde na América Latina: tendéncias e perspectivas. Brasília, OPAS, 1982.

31.NOGUEIRA, R.P. A força de trabalho em saúde. Rev. Adm. Publica, 17:61-70, 1983. 
32.NOGUEIRA, R.P. Emprego em saúde por natureza jurídico-administrativa dos estabelecimentos, 1981-1987. Bol. Inf. RH-SUS, 1(1):8-9, 1992.

33.ORGANIZACION PANAMERICANA DE SALUD. Salud para todos en el año 2000. Estrategias. Washington,DC, 1980. (Documento oficial, 173)

34.ORGANIZACION PANAMERICANA DE SALUD. Desarrollo y fortalecimento dos sistemas locales de salud en la transformacion de los sistemas nacionales de salud. Washington, DC, 1989.

35.ORGANIZACION PANAMERICANA DE SALUD. Programa de Desarrollo de Servicios de Salud. Los Sistemas Locales de Salud: aspectos conceptuales y metodologicos. Washington, DC, 1988. 88p.

36.PIERANTONI, C.R. \& MACHADO, M.H. Profissర̃es de saúde: a formação em questão. In: CONFERÉNCIA NACIONAL DE RECURSOS HUMANOS PARA A SAÚDE, $2^{\mathrm{a}}$, Brasília, 1993. Textos apresentados. Cad. RH Saúde, 1(3):23-34, 1993.

37.PINTO, V.G. Saúde bucal: panorama internacional. Brasília, Ministério da Saúde, 1990.

38.REDE CEDROS. GRUPO DE TRABALHO SAÚDE BUCAL EM SISTEMAS LOCAIS DE SAÚDE. O que fazer nos municípios? Rio de Janeiro, 1992. (Cadernos de Saúde Bucal, 1)

39.ROCK, W.P. \& BRADNOCK, G. The employment of dental higienists within the General Dental Service in the United Kingdom. Br. Dent. J., 140:351-2, 1976.

40.ROSA, A.G.F.; LIA NETO, J.; SERIO, H.B. Avaliação da assistência odontológica no sistema local de saúde de São José dos Campos-SP. Divulg. Saúde Debate, 6:5560, 1991.

41.SADER, E. Quando novos personagens entraram em cena. Rio de Janeiro, Paz e Terra, 1988. p.55

42.SÃO PAULO. SECRETARIA DE ESTADO DA SAÚDE Convênio para implantação e execução do programa de açठ́es integradas de saúde. Diário Oficial do Estado de Săo Paulo, Såo Paulo, 27 out. 1983.

43.SÃO PAULO. SECRETARIA DE ESTADO DA SAÚDE Programa estadual de saúde bucal: diretrizes para os programas regionais e municipais de saúde. Diário Oficial do Estado de Săo Paulo, São Paulo, 18 jun. 1989.

44.SÃO PAULO. SECRETARIA MUNICIPAL DA SAÚDE. Relatório sobre a situação dos atendentes de enfermagem. São Paulo, CEFOR-Projeto Larga Escala, 1994. 
45.SCHNEIDER FILHO, D.A. Construindo a saúde bucal coletiva no municipio de São Paulo. Divulg. Saúde Debate, 6:76-85, 1991.

46.SCHOU, L.; TRONBJERG, C.; HOLST, I. A national survey of dental hygienists in Denmark. Community Dent. Health, 3:19-8, 1986.

47.SCHRAIBER, L.B.; PEDUZZI, M. Tendências e possibilidades da investigação de recursos humanos em saúde no Brasil. São Paulo, 1992.

48.STEELE, L.P. Dental nurses in Trinidad and Tobago. Bull. Pan Am. Health Organ., 22: 493-99, 1988.

49.TABACOF, G. Pesquisa dos recursos institucionais no setor saúde, área de odontologia, na cidade de Salvador. Salvador, UFBA, 1977.

50.TOLEDO, J.P.G. A saúde bucal no Estado de São Paulo: das AIS ao SUS. São Paulo, 1991.

51.UITENBROEK, D.G.; SCHAUB, R.M.H.; TROMP, J.A.H.; KANT, J.H. Dental hygienists'influence on the patients'knowledge, motivation, self-care, and perception of change. Community Dent. Oral Epidemiol., 17:87-90, 1989.

52.VASCONCELOS, M.C.C. O assistente odontológico na equipe de prestação de serviços odontológicos. Rev. Saúde Pública, 14:123-36, 1980.

53.WALDMAN, H.B. Dentists and dentistry changed in the 1980's. J. Am. Coll. Dent., 56:413, 1989.

54.WALSH, M.M. The economic contribution of dental hygienists' activities to dental practice: review of the literature. J. Public Health Dent., 47:193-7, 1987. 


\section{ANEXO I}

\section{QUESTIONÁRIO - PESSOAL AUXILIAR ODONTOLÓGICO}

1. SEXO: feminino... ( ) (1) masculino..() (2)

2. IDADE: em anos completos: anos

3. Você exerce a função de: auxiliar de odontologia....( )(1) técnico em higiene dental..( ()(2)

4. Até que grau você estudou ?

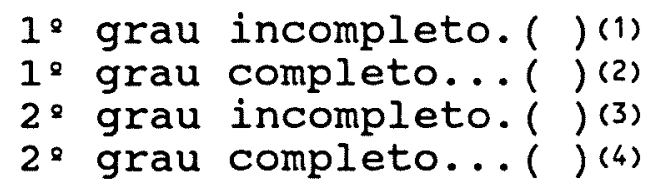

5. Você fez curso de: Sim Não

$5 \mathrm{~A}$. atendente de consultório dentário.? Sim ou não....( )(1) ( )(2)

5B. técnico em higiene dental ? Sim ou não........... (1) (1) (2)

6. No momento você está fazendo curso de:

Sim Não

6A. atendente de consultório dentário.? Sim ou não...( (1)(1) ( )(2)

6B. técnico em higiene dental ? Sim ou não.........( )(1) ( )(2)

7. Você teria interesse em fazer curso de:

$7 A$. atendente de consultório dentário, $\operatorname{sim}$ Não Não tenho opinia ou você não tem opinião ?..( ()(1) ( )(2) ( )(3)

7B. técnico em higiene dental, ou você não tem opinião ?..( ()(1) ( )(2) ( )(3)

8. Quem paga o seu salário: Prefeitura, apenas...( ()(1)

Estado, apenas...( )(2)

INAMPS, apenas...( ) (3)

Prefeitura + Estado..( ()(4)

Prefeitura + INAMPS..( )(5)

9. O seu último salário foi de:

9A. recebido no mês de:

10. Segundo o seu comprovante de pagamento (hollerith), você está registrada em qual cargo ou função?

Função:

11. Quantas horas por semana você trabalha?

20 horas/semana....( )(1)

30 horas/semana....( )(2)

40 horas/semana.... ( ) (3)

região: 
12. Dessas horas por semana, quantas você dedica :

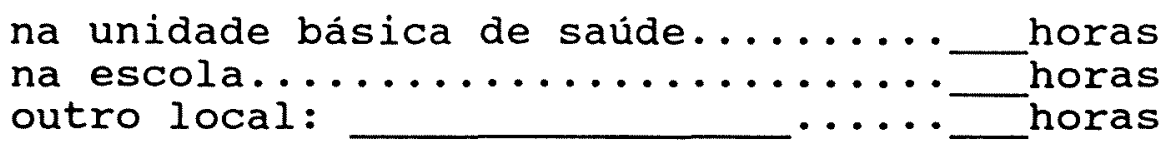

13. Para o atendimento clínico de pacientes você:

13A. prepara a sala de odonto, sim ou não?......... Sim)(1) ( )(2)

13B. limpa e desinfeta materiais, sim ou não?....... (1) (1)(2)

13C. esteriliza instrumentos, sim ou não?.......... (1) ( )(2)

13D. prepara cimentos e outros materiais, sim ou não?.( )(1) ( )(2)

13E. trabalha à quatro-mãos, sim ou não?.......... (1) (1) (2)

14. No atendimento clinico de pacientes, portanto em cadeira odontológica, você faz :

14A. aplicação tópica de flúor. Sim Não

14B. aplicação de selante, sim ou não?............ (1) ( )(2)

14C. aplicação de cariostático, sim ou não?......... (1) ( )(2)

14D. polimento dentário, sim ou não?............. (1) ( )(2)

14E. remoção de tártaro, sim ou não?.............. (1) ( )(2)

$14 \mathrm{~F}$. inserção e condensação de materiais

restauradores, sim ou não?..( )(1) ( )(2)

15. Na prevenção da cárie dentária você faz EVIDENCIAÇÃo DE PLACA BACTERIANA SEGUIDA DE ESCOVAÇÃO SUPERVISIONADA, Sim ou não ?

$$
\text { Sim ( ) (1) Não ( ) (2)PASSE PARA A QUESTÃo } 18
$$

Se você respondeu sim, indique na linha do local em que você faz, qual a frequência (ou por semana ou por mês ou por ano) e para quantas pessoas aproximadamente em cada vez:

FREQUÊNCIA(ABC) TOTAL DE PESSOAS ( $n^{2}$ de vezes por sem/mès/ano) EM CADA VEZ(D)

16. UNIDADE BÁSICA DE SAÚDE por

por CRECHE/OUTRO LOCAL 
18. Na prevenção da cárie dentária você faz APLICAÇÃo DE BOCHECHOS FLUORADOS, sim ou não ?

$$
\text { Sim ( )(1) Não ( ) (2)PASSE PARA A QUESTÃo } 21
$$

Se você respondeu sim, indique na linha do local em que você faz, qual a frequência (ou por semana ou por mês ou por ano) e para quantas pessoas aproximadamente em cada vez:

FREQUÊNCIA(ABC)

( $n^{2}$ de vezes por sem/mès/ano)
TOTAL DE PESSOAS EM CADA VEZ(D)

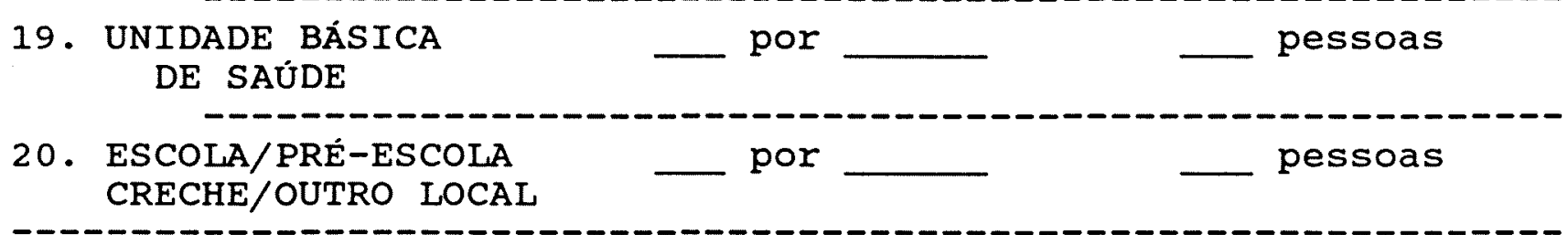

$19 A$

21. Na prevenção da cárie dentária você faz APLICAÇÃo DE FLÚOR COM ESCOVA OU MOLDEIRA, sim ou não ?

$$
\text { Sim ( ) (1) Não ( ) (2)PASSE PARA A QUESTÃo } 24
$$

Se você respondeu sim, indique na linha do local em que você faz, qual a frequência (ou por semana ou por mês ou por ano) e para quantas pessoas aproximadamente em cada vez:

\section{FREQUENCIA(ABC) TOTAL DE PESSOAS ( $n^{2}$ de vezes por sem/mès/ano) EM CADA VEZ(D)}

22. UNIDADE BÁSICA por pessoas DE SAÚDE

por pessoas CRECHE/OUTRO LOCAL

24. Na prevenção da cárie dentária, você dá ORIENTAÇõEs INDIVIDUAIS, isto é, com uma pessoa de cada vez, sim ou não ?

$$
\text { Sim ( )(1) Não ( ) (2)PASSE PARA A QUESTÃo } 27
$$

Se você respondeu sim, indique na linha do local em que você faz, qual a frequência (ou por dia ou por semana)

e para quantas pessoas aproximadamente por dia ou por semana:

FREQUENNCIA(AB)

( $n^{2}$ de vezes por dia/semana) TOTAL DE PESSOAS(C)

25. UNIDADE BÁSICA

por

pessoas

- por

por

pessoas 
27. Na prevenção da cárie dentária você dá ORIENTAÇõES PARA GRUPOS DE PESSOAS: PALESTRAS, REUNIŌES, sim ou não ?

$$
\text { Sim ( )(1) Não ( ) (2)PASSE PARA A QUESTÃo } 30
$$

Se você respondeu sim, indique na linha do local em que você faz, qual a frequência (ou por semana ou por mês ou por ano) e para quantas pessoas aproximadamente em cada vez:

FREQUENCIA(ABC)
28. UNIDADE Bezes por sem/mês/ano)
DE SAÚDE
29. ESCOICA
CRECHE/PRÉ-ESCOLA

30. Para avaliação da situação de cárie, você auxilia ou já auxiliou o dentista nas atividades de exame ou levantamento de cárie em grupos populacionais, sim ou não ?

$$
\operatorname{sim}()(1) \quad \text { Não ( )(2) }
$$

31. Na sua opinião, durante as atividades de prevenção da cárie dentária (escovações, bochechos, orientações, etc) que você faz, as pessoas que recebem essas atividades:

(assinale apenas uma questão)

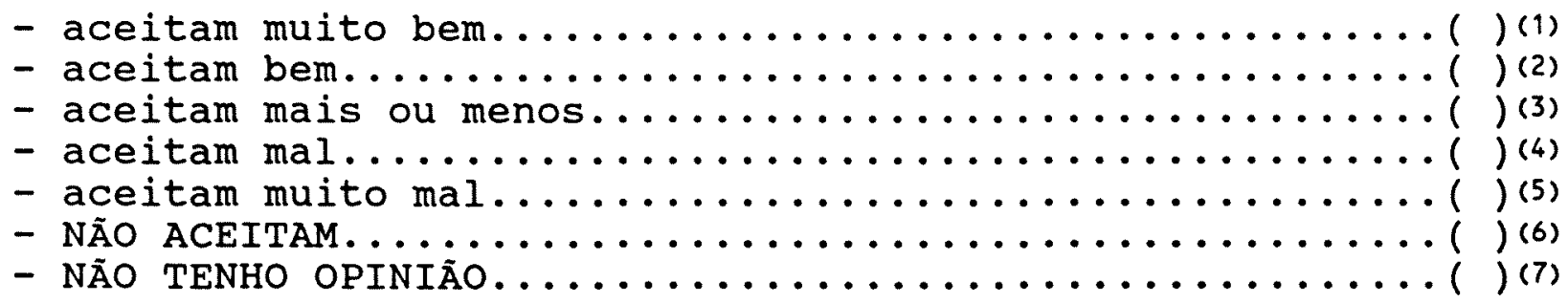

32. Na sua opinião, você considera o relacionamento profissional dos dentistas com você :

(assinale apenas uma questão)

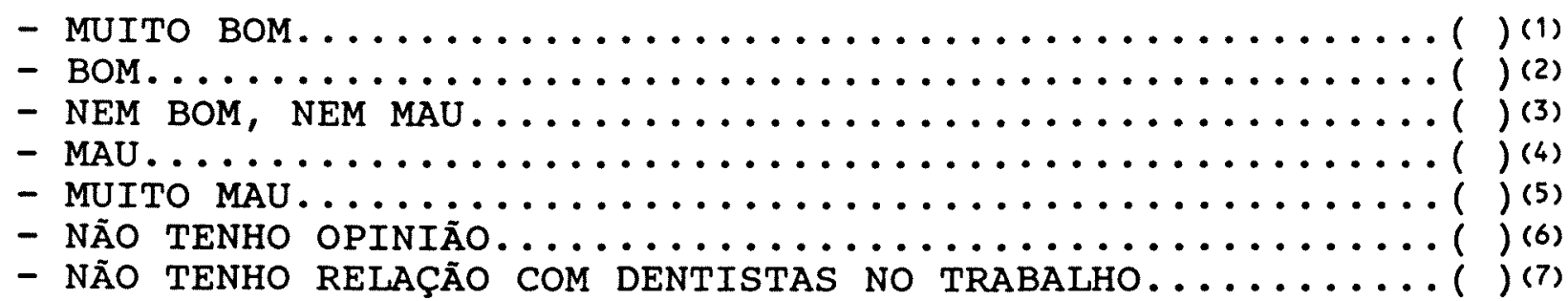


33. Na sua opinião, durante o trabalho, os dentistas:

(assinale apenas uma questão)

- observam, corrigem e orientam o seu trabalho.......... ( ) (1)

- orientam, sempre que você solicita................. (2) (2)

- às vezes orientam quando você solicita, às vezes não...( )(3)

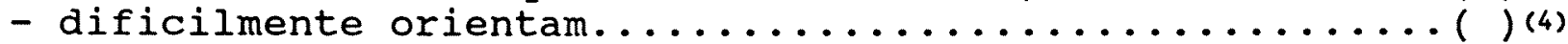

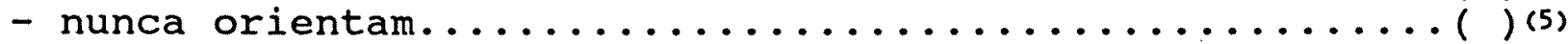

- não tenho opinião........................... ( ) (6)

- não tenho relação com dentistas no trabalho........... ( ) (7)

34. Na sua opinião, você acha que os dentistas devem:

(assinale apenas uma questão)

- orientar mais o seu trabalho.................... ( ) (1)

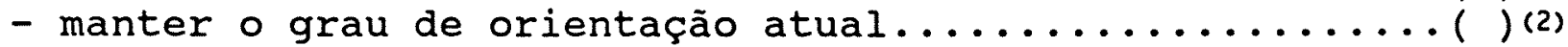

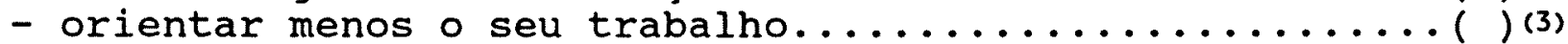

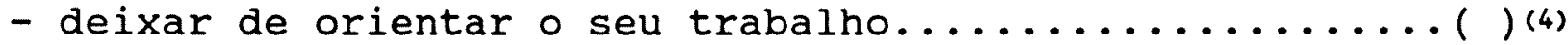

- não tenho opinião............................ ( ) (5)

35. Na sua opinião, você considera o relacionamento profissional de outros auxiliares com você :

(assinale apenas uma questão)

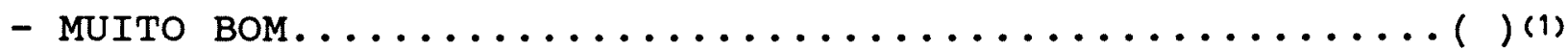

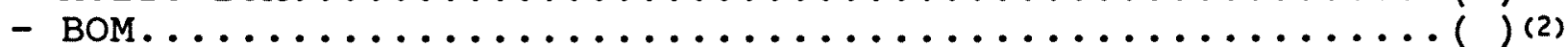

- NEM BOM, NEM MAU........................ () (3)

- MAU................................... ( ) (4)

- MUITO MAU............................... ( ) (5)

- NÃO TENHO OPINIÃO .......................... ( ) (6)

- NÃO TENHO RELAÇÃO COM OUTROS AUXILIARES NO TRABALHO....( ) (7)

36. Na sua opinião, durante o trabalho, os auxiliares:

(assinale apenas uma questão)

- dividem bem o trabalho entre si, tem ótima cooperação..( )(1)

- raramente um trabalha mais que outro................ ( ) (2)

- às vezes um trabalha mais que outro................. () (3)

- frequentemente um trabalha mais que outro............. ( ) (4)

- não há cooperação, sempre um trabalha mais que outro...( )(5)

- não tenho opinião........................... ( ) (6)

- não tenho relação com outros auxiliares no trabalho....( )(7)

37. Na sua opinião, deve-se aumentar o número de auxiliares para : (assinale apenas uma questão)

- auxiliar mais os dentistas nos consultórios........... ( )(1)

- fazer mais atividades de prevenção fora dos consultórios ( )(2)

- não tenho opinião............................ ( ) (3) 


\section{ANEXO II}

As tabelas 31 a 37 apresentam os cálculos efetuados para estimar a participação do PAO no provimento de açōes coletivas em escolas/espaços sociais e unidades básicas de saúde. A partir delas foram produzidos os gráficos $6,7,8$ e 9 apresentados no capitulo 5 .

\section{TABELA 31}

Rendimento do pessoal auxiliar que declarou realizar atividades coletivas de bochechos fluorados semanais ou quinzenais em escolas e outros espaços sociais, segundo o SILOS, 1994.

\begin{tabular}{lcrrrrr}
\hline \multicolumn{1}{c}{ SILOS } & $\begin{array}{c}\text { Pessoas } \\
\text { beneficiadas }\end{array}$ & média/auxiliar & dp & horas/semana & $\begin{array}{c}\text { número de } \\
\text { auxiliares }\end{array}$ & $\begin{array}{c}\text { total } \\
\text { horas/mês }\end{array}$ \\
\hline Itú & 12200 & 2033,3 & 81,6 & 16,3 & 6 & 391,2 \\
Embú & 10090 & 840,8 & 32,5 & 6,7 & 12 & 322,8 \\
Penápolis & 3000 & 375,0 & 70,7 & 3,0 & 8 & 96,0 \\
SJC-Centro & 12428 & 877,7 & 252,1 & 7,1 & 14 & 397,6 \\
SJC-Norte & 12942 & 1438,0 & 1659,7 & 11,5 & 9 & 414,0 \\
SJC-Sul & 23744 & 879,4 & 362,9 & 7,0 & 27 & 759,6 \\
SJC-Leste & 20400 & 1133,3 & 1035,8 & 9,0 & 18 & 652,8 \\
Camp-Oeste & - & - & - & - & - & - \\
Camp-Leste & 240 & 240,0 & - & 1,9 & 1 & 7,6 \\
Camp-Norte & 300 & 300,0 & - & 2,4 & 1 & 9,6 \\
\hline
\end{tabular}

parâmetro: 5000 bochechos em $40 \mathrm{hs} / \mathrm{sem}$ 


\section{TABELA 32}

Rendimento mensal do pessoal auxiliar que declarou realizar atividades coletivas de evidenciação de placa bacteriana seguida por escovação supervisionada em escolas, creches e outros e espaços sociais, segundo o SILOS, 1994.

\begin{tabular}{lrrrrrr}
\hline SILOS & $\begin{array}{c}\text { Pessoas } \\
\text { beneficiadas }\end{array}$ & média/auxiliar & dp & horas/mês & $\begin{array}{c}\text { número de } \\
\text { auxiliares }\end{array}$ & $\begin{array}{r}\text { total } \\
\text { horas/m }\end{array}$ \\
\hline Itú & 1120 & 124,4 & 118,2 & 4,2 & 9 & $37, \varepsilon$ \\
Embú & 3037 & 253,1 & 253,1 & 8,4 & 12 & $100, \varepsilon$ \\
Penápolis & 10700 & 1337,5 & 504,1 & 44,6 & 8 & $356, \varepsilon$ \\
SJC-Centro & 6195 & 442,5 & 457,8 & 14,7 & 14 & 205,1 \\
SJC-Norte & 10320 & 1290,0 & 1517,8 & 43,0 & 8 & 344,1 \\
SJC-Sul & 26988 & 1038,0 & 794,5 & 34,6 & 26 & 899,1 \\
SJC-Leste & 27124 & 1291,6 & 1388,3 & 43,1 & 21 & 905, \\
Camp-Oeste & 1302 & 144,7 & 191,0 & 4,8 & 9 & 43, \\
Camp-Leste & 160 & 240,0 & - & 8,0 & 4 & 32,1 \\
Camp-Norte & 602 & 150,5 & 115,1 & 5,0 & 4 & 20,1 \\
\hline
\end{tabular}

parâmetro: 4800 atividades em $160 \mathrm{hs} / \mathrm{mês}$

TABELA 33

Rendimento mensal do pessoal auxiliar que declarou realizar atividades coletivas de aplicação de flúor com escova ou moldeira em escolas, creches e outros espaços sociais, segundo o SILOS, 1994.

\begin{tabular}{lcccccc}
\hline \multicolumn{1}{c}{ SILOS } & $\begin{array}{c}\text { Pessoas } \\
\text { beneficiadas }\end{array}$ & média/auxiliar & dp & horas/mês & $\begin{array}{c}\text { número de } \\
\text { auxiliares }\end{array}$ & $\begin{array}{c}\text { total } \\
\text { horas/n }\end{array}$ \\
\hline Itú & 180 & 60,0 & - & 4,0 & 3 & 12,6 \\
Embú & 2401 & 200,1 & 148,8 & 13,3 & 12 & 159,6 \\
Penápolis & - & - & - & - & - & - \\
SJC-Centro & 5840 & 417,1 & 567,1 & 27,8 & 14 & 389, \\
SJC-Norte & 5568 & 696,0 & 645,3 & 46,4 & 8 & 371, \\
SJC-Sul & 13269 & 510,3 & 813,1 & 34,0 & 26 & 884, \\
SJC-Leste & 15698 & 747,5 & 1472,5 & 49,8 & 21 & 1045 , \\
Camp-Oeste & - & - & - & - & - & - \\
Camp-Leste & - & - & - & - & - & - \\
Camp-Norte & - & - & - & - & - & - \\
\hline
\end{tabular}

parâmetro: 2400 atividades em 160 hs/mês. 


\section{TABELA 34}

Rendimento mensal do pessoal auxiliar que declarou realizar atividades coletivas de orientação sobre prevenção da cárie dentária através de palestras/reunið̃es em escolas, creches e outros espaços sociais, segundo o SILOS, 1994.

\begin{tabular}{lcccccc}
\hline \multicolumn{1}{c}{ SILOS } & $\begin{array}{c}\text { Pessoas } \\
\text { beneficiadas }\end{array}$ & média/auxiliar & dp & horas/mês & $\begin{array}{c}\text { número de } \\
\text { auxiliares }\end{array}$ & $\begin{array}{c}\text { total } \\
\text { horas/mês }\end{array}$ \\
\hline Itú & 6581 & 940,1 & 995,8 & 23,5 & 7 & 164,5 \\
Embú & 3450 & 345,0 & 344,6 & 8,6 & 10 & 86,0 \\
Penápolis & 3601 & 900,3 & 466,5 & 22,5 & 4 & 90,0 \\
SJC-Centro & 2690 & 336,3 & 230,9 & 8,4 & 8 & 67,2 \\
SJC-Norte & 5280 & 880,0 & 944,5 & 22,0 & 6 & 132,0 \\
SJC-Sul & 13890 & 817,1 & 548,6 & 20,4 & 17 & 346,8 \\
SJC-Leste & 16743 & 881,2 & 1544,4 & 22,0 & 19 & 418,0 \\
Camp-Oeste & 2187 & 243,0 & 124,5 & 6,1 & 9 & 54,9 \\
Camp-Leste & 960 & 240,0 & - & 6,0 & 4 & 24,0 \\
Camp-Norte & 310 & 155,0 & 134,4 & 3,9 & 2 & 7,8 \\
\hline parâmetro: 40 individuos por hora, 6400 em 160 hs/mês. & & &
\end{tabular}

TABELA 35

Rendimento mensal do pessoal auxiliar que declarou realizar atividades coletivas de evidenciação de placa bacteriana seguida por escovação supervisionada em unidades básicas de saúde segundo o SILOS, 1994.

\begin{tabular}{lcccccc}
\hline \multicolumn{1}{c}{ SILOS } & $\begin{array}{c}\text { Pessoas } \\
\text { beneficiadas }\end{array}$ & média/auxiliar & dp & horas/mês & $\begin{array}{c}\text { número de } \\
\text { auxiliares }\end{array}$ & $\begin{array}{c}\text { total } \\
\text { horas/mês }\end{array}$ \\
\hline Itú & 3044 & 253,7 & 204,9 & 63,4 & 12 & 761,1 \\
Embú & 3010 & 376,3 & 46,3 & 94,1 & 8 & 752,8 \\
Penápolis & 600 & 300,0 & 141,4 & 75,0 & 2 & 150,0 \\
SJC-Centro & 16 & 16,0 & - & 4,0 & 1 & 4,0 \\
SJC-Norte & 28 & 28,0 & - & 7,0 & 1 & 7,0 \\
SJC-Sul & - & - & - & - & - & - \\
SJC-Leste & - & - & - & - & - & - \\
Camp-Oeste & 268 & 33,5 & 28,5 & 8,4 & 8 & 67,0 \\
Camp-Leste & 614 & 68,2 & 53,8 & 17,1 & 9 & 153,9 \\
Camp-Norte & 370 & 61,7 & 63,4 & 15,4 & 6 & 92,4 \\
\hline
\end{tabular}

parâmetro: 640 atividades em $160 \mathrm{hs} / \mathrm{mês}$ 


\section{TABELA 36}

Rendimento mensal do pessoal auxiliar que declarou realizar atividades coletivas de aplicação de flúor com escova ou moldeira em unidades básicas de saúde, segundo o SILOS, 1994

\begin{tabular}{lcccccc}
\hline \multicolumn{1}{c}{ SILOS } & $\begin{array}{c}\text { Pessoas } \\
\text { beneficiadas }\end{array}$ & médialauxiliar & dp & horas/mês & $\begin{array}{c}\text { número de } \\
\text { auxiliares }\end{array}$ & $\begin{array}{c}\text { total } \\
\text { horas/mès }\end{array}$ \\
\hline Itú & 260 & 86,7 & 98,7 & 28,8 & 3 & 86,7 \\
Embú & 960 & 160,0 & - & 53,3 & 6 & 319,9 \\
Penápolis & - & - & - & - & - & - \\
SJC-Centro & - & - & - & - & - & - \\
SJC-Norte & - & - & - & - & - & - \\
SJC-Sul & - & - & - & - & - & - \\
SJC-Leste & - & - & - & - & - & - \\
Camp-Oeste & - & - & - & - & - & - \\
Camp-Leste & 220 & 73,3 & 11,5 & 24,4 & 3 & 73,2 \\
Camp-Norte & 145 & 72,5 & 38,9 & 24,2 & 2 & 48,4 \\
\hline parâmetro: 480 & atividades
\end{tabular}

parâmetro: 480 atividades em $160 \mathrm{hs} / \mathrm{mês}$.

\section{TABELA 37}

Rendimento mensal do pessoal auxiliar que declarou realizar atividades coletivas de orientação sobre prevenção da cárie dentária através de palestras/reuniðes em unidades básicas de saúde, segundo o SILOS, 1994.

\begin{tabular}{|c|c|c|c|c|c|c|}
\hline SILOS & $\begin{array}{c}\text { Pessoas } \\
\text { beneficiadas }\end{array}$ & média/auxiliar & $d p$ & horas/mês & $\begin{array}{l}\text { número de } \\
\text { auxiliares }\end{array}$ & $\begin{array}{c}\text { total } \\
\text { horas/mês }\end{array}$ \\
\hline Itú & - & - & - & - & - & - \\
\hline Embú & 1220 & 203,3 & 148,8 & 10,2 & 6 & 61,2 \\
\hline Penápolis & - & - & - & - & - & - \\
\hline SJC-Centro & - & - & - & - & - & - \\
\hline SJC-Norte & - & - & - & - & - & - \\
\hline SJC-Sul & - & - & - & - & - & - \\
\hline SJC-Leste & - & - & - & - & - & - \\
\hline Camp-Oeste & 291 & 32,3 & 22,1 & 1,6 & 9 & 14,4 \\
\hline Camp-Leste & 710 & 88,7 & 48,2 & 4,4 & 8 & 35,2 \\
\hline Camp-Norte & 174 & 29,0 & 20,4 & 1,5 & 6 & 9,0 \\
\hline
\end{tabular}

